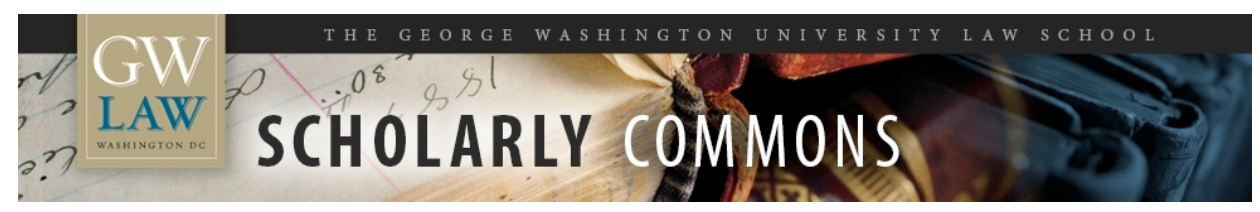

GW Law Faculty Publications \& Other Works

Faculty Scholarship

2004

\title{
Assessing the Legality of Invading Iraq
}

Sean D. Murphy

George Washington University Law School, smurphy@law.gwu.edu

Follow this and additional works at: https://scholarship.law.gwu.edu/faculty_publications

Part of the Law Commons

\section{Recommended Citation}

Sean D. Murphy, Assessing the Legality of Invading Iraq, 92 Geo. L.J. 173 (2004).

This Article is brought to you for free and open access by the Faculty Scholarship at Scholarly Commons. It has been accepted for inclusion in GW Law Faculty Publications \& Other Works by an authorized administrator of Scholarly Commons. For more information, please contact spagel@law.gwu.edu. 
Draft August 1, 2003

\title{
ASSESSING THE LEGALITY OF INVADING IRAQ
}

\author{
Sean D. Murphy \\ George Washington University Law School \\ 2000 H Street, N.W. \\ Washington, D.C. 20520 \\ (202) 994-8763 (tel) \\ smurphy@law.gwu.edu
}

Forthcoming 92 GEORGETOWN LAW JOURNAL Issue No. 4 (2004)

[The author extends his thanks to David Abramowitz, Michael Byers, Michael J. Matheson, Mary Ellen O'Connell, Leila Sadat, Ralph G. Steinhardt, and Geoffrey R. Watson for their extremely helpful comments on an earlier draft, and to James Menz, GW J.D. '05 for superb research assistance. The views contained herein and any errors are attributable solely to the author].

\section{INTRODUCTION}

In March 2003, a small group of states led by the United States ${ }^{1}$ invaded Iraq. Determining the exact policy reason for invading Iraq is a somewhat complicated task; government officials offered a variety of policy justifications that differed in their emphases depending on the audience being addressed, and that evolved over time. In some instances, U.S. officials expressed concern for U.S. national security, sometimes relating to the threat of terrorism. In other instances, U.S. officials asserted a need to protect Iraq's neighbors or the international community at large, including the need to uphold resolutions of the UN Security Council ordering Iraqi disarmament of weapons of mass destruction (WMD). At times, attention was called to the welfare of the Iraqi people and the

${ }^{1}$ The ground forces for the invasion involved approximately 125,000 U.S. forces and 45,000 U.K. forces, but also included approximately 2,000 Australian forces, and 600 Czech, Polish, and Slovak forces. In addition, these countries contributed approximately 67,400 sea and air forces. See The War in Numbers, WASH. Post, Apr. 20, 2003, at A20. 
need to help them throw off a despotic and abusive ruler. ${ }^{2}$ Many critics noted the importance of Iraq in a region from which the United States and the global community derive energy resources.

${ }^{2}$ See, e.g., Address to the Nation on Iraq, 39 WeEKLy CoMP. PRES. Doc. 338, 338-41 (Mar. 17, 2003) (speech by President Bush referring to Iraq's violation of UN resolutions, its history of aggression, its assistance to terrorists, mistreatment of Iraqi nationals, and the need not to appease "murderous dictators"); Address to the Nation on Iraq, 39 WEEKLY COMP. PRES. DOC. 342, 342 (Mar. 19, 2003) ("... American and coalition forces are in the early stages of military operations to disarm Iraq, to free its people, and to defend the world from grave danger."). 
As for the basis for the invasion of Iraq under international law, ${ }^{3}$ in the months leading up to March 2003, considerable attention was paid to the doctrine of "preemptive self-defense" expressed by the Bush administration in its September 2002 report to the Congress on national security. That report, among other things, asserted an evolving right under international law for the United States to use military force preemptively against the threat posed by "rogue states" possessing WMD. ${ }^{4}$ The doctrine no doubt was attractive to the Bush administration, as it resonated

${ }^{3}$ This article does not address the issue of whether the U.S. invasion was in accordance with U.S. law. In October 2002, Congress adopted and President Bush signed into law a Congressional authorization stating:

The President is authorized to use the Armed Forces of the United States as he determines to be necessary and appropriate in order to-

(1) defend the national security of the United States against the continuing threat posed by Iraq; and

(2) enforce all relevant United Nations Security Council resolutions regarding Iraq.

Authorization for Use of Military Force Against Iraq Resolution of 2002, Pub. L. No. 107-243, 116 Stat. 1498 (2002). For an unsuccessful effort by some congressmen and other plaintiffs to obtain judicial review of the constitutionality of the statute, see Doe v. Bush, 240 F. Supp.2d 95, 96 (D. Mass. 2003), aff'd, 322 F.3d 109 (1st Cir. 2003); see also Jordan J. Paust, Use of Armed Force against Terrorists in Afghanistan, Iraq, and Beyond, 35 CORNELL INT'L L.J. 533, 548-56 (2002).

${ }^{4}$ The White House, The National Security Strategy of the United States of AMERICA 13-16 (Sept. 17, 2002), at <http://www.whitehouse.gov/nsc/nss.pdf $>$. Other expressions of the doctrine may be found at White House, NATIONAL STRATEGY TO COMBAT WEAPONS OF MASS DESTRUCTION (Dec. 2002), at <http://www.whitehouse.gov>; Commencement Address at the United States Military Academy in West Point, New York, 38 WeEKLy COMP. PRES. Doc. 944 (June 10, 2002) ("our security will require all Americans to be forward-looking and resolute, to be ready for preemptive action when necessary to defend our liberty and to defend our lives"); Secretary of Defense Donald H. Rumsfeld, Annual Report to the President and the Congress, 30 (2002) ("defending the United States requires prevention and sometimes preemption”); Richard N. Haass, Director, U.S. Dep’t of State Policy Planning Staff, Sovereignty: Existing Rights, Evolving Responsibilities, Remarks at Georgetown University (Jan. 14, 2003), at <http://www.state.gov>. The doctrine of preemptive self-defense was 
with the fears of many Americans - in the aftermath of the September 11, 2001, attacks by the terrorist organization Al Qaeda — that at some point WMD would be unleashed against the United States by rogue elements. ${ }^{5}$ Yet, ultimately, when explaining the legal basis for its action against Iraq, the United States did not assert that the invasion of Iraq was permissible under international law due to an evolving right of preemptive self-defense ${ }^{6}$ (nor that international law was irrelevant ${ }^{7}$ ). Rather,

controversial when announced and there are reasons to doubt its validity on both legal and policy grounds. See, e.g., Michael Byers, Preemptive Self-Defense: Hegemony, Equality, and Strategies of Legal Change, 11 J. POL. PHIL. 171 (2003) (arguing that through such a doctrine the United States is advocating what amounts to an "imperial system" of international law); Neta C. Crawford, The Slippery Slope to Preventive War, 17 ETHICS \& INT’L AfFAIRS (2003) (arguing that a preventive offensive war doctrine undermines international law and diplomacy, both of which can be useful, even to hegemonic powers); John J. Mearsheimer \& Stephen M. Walt, An Unnecessary War, FOR. POL'Y, Jan./Feb. 2003, at 51 (arguing that Iraq's leader, Saddam Hussein, was eminently capable of being deterred and did not pose a future threat to the global community); but see W. Michael Reisman, Assessing Claims to Revise the Law of War, 97 AM. J. INT'L L. 82 (suggesting that such a doctrine of preemptive self-defense may contribute to world public order if subjected to appropriate criteria).

${ }^{5}$ When President Bush announced to the nation that military operations against Iraq had begun in March 2003, he said:

The people of the United States and our friends and allies will not live at the mercy of an outlaw regime that threatens the peace with weapons of mass murder. We will meet that threat now, with our Army, Air Force, Navy, Coast Guard and Marines, so that we do not have to meet it later with armies of firefighters and police and doctors on the streets of our cities.

Address to the Nation on Iraq, 39 WeEkLy COMP. Pres. Doc. 342, 343 (Mar. 19, 2003).

${ }^{6}$ See, e.g., Congressional Research Service, U.S. Use of Preemptive Military Force, CRS Report RS21311 (Apr. 11, 2003) ("The President did not explicitly characterize his military action as an implementation of the expansive concept of preemptive use of military force against rogue states with WMD contained in his National Security Strategy document of September 2002.").

${ }^{7}$ See, e.g., Kim R. Holmes, U.S. Dep't of State Assistant Secretary for International Organization Affairs, The Future of U.S.-UN Relations, Remarks at the XXI German American Conference (June 13, 2003), at <http://www.state.gov>: 
the United States asserted that the invasion was lawful because it was authorized by the Security

Council. ${ }^{8}$ That authorization was not issued in 2002-2003 but, rather, in 1990 when the Security

As contentious as the disagreement over Iraq was, it should not be overemphasized. Neither the United States nor the U.K. ever asserted a right to operate outside their obligations under international law. Neither took a position that called into question the existing international legal regime related to the use of force. Each country had lawyers examine relevant resolutions and clarify the legal basis for use of force before the decision to proceed was made.

${ }^{8}$ See Letter dated 20 March 2003 from the Permanent Representative of the United States of America to the United Nations addressed to the President of the Security Council, UN Doc. S/2003/351 (Mar. 21, 2003) ("The actions being taken are authorized under existing Council resolutions ..."); see also Address to the Nation on Iraq, 39 WeEKLy COMP. PrES. Doc. 338, 339 (Mar. 17, 2003) ("Under Resolutions 678 and 687, both still in effect, the United States and our allies are authorized to use force in ridding Iraq of weapons of mass destruction. This is not a question of authority. It is a question of will.”); Remarks of U.S. Department of State Legal Adviser William H. Taft, IV, before the National Association of Attorneys General at 15-16 (Mar. 20, 2003), at <http://usinfo.state.gov/regional/nea/iraq/text2003/032129taft.htm> ("Under international law, the basis for use of force is equally strong. There is clear authorization from the Security Council to use force to disarm Iraq."); UN Doc. S/PV.4726 (resumption 1), at 25 (Mar. 27, 2003) (statement of U.S. Permanent Representative to the United Nations to the Security Council) ("Resolution 687 (1991) imposed a series of obligations on Iraq that were the conditions of the ceasefire. It has long been recognized and understood that a material breach of those obligations removes the basis of the ceasefire and revives the authority to use force under resolution 678 (1990)."); Holmes, supra note 7 ("The decision to go to war with Iraq was based on international law: Existing Security Council resolutions against Iraq provided sufficient legal basis for military action.")

Some of these various statements also contain brief and cryptic references suggesting legal authority other than emanating from Security Council resolutions. See, e.g., Letter dated 20 March 2003, supra, at 2 ("The actions that coalition forces are undertaking . . are necessary steps to defend the United States . . f from the threat posed by Iraq ..."); Address to the Nation on Iraq, supra, at 339 ("The United States of America has the sovereign authority to use force in assuring its own national security."); Remarks of U.S. Department of State Legal Adviser William H. Taft, IV, supra, at 16 ("The President may also, of course, always use force under international law in self-defense."). As such, a doctrine of preemptive selfdefense may be viewed as an unstated or subsidiary legal basis for the United States. This article, however, focuses on the explicit and principal international legal justification advanced by the United States, which is the only justification shared by its coalition allies, such as the United Kingdom. See infra note 10. 
Council adopted Resolution $678,{ }^{9}$ and thereby authorized a coalition of states to repel Iraq from Kuwait and to restore peace and security in the area. Although the 1990-91 war against Iraq ended with a UN-mandated cease-fire, Iraq violated its obligations under that cease-fire, thus - according to the United States - such "material breach" of the cease-fire conditions had the effect of "reviving" the earlier authorization to use force. The same legal theory was asserted by other members of the

\footnotetext{
${ }^{9}$ SC Res. 678 (Nov. 29, 1990).
} 
U.S.-led coalition. ${ }^{10}$

${ }^{10}$ For convenience, the theory is referred to in this article as the "U.S. legal theory," but it was shared by the other states in the U.S.-led coalition. For the letter from Australia letter to the Security Council, see UN Doc. S/2003/352 (Mar. 20, 2003). For the U.K. letter to the Security Council, see UN Doc. S/2003/350 (Mar. 21, 2003). For the legal analysis of the U.K. Attorney-General, see Attorney-General Clarifies Legal Basis for Use of Force Against Iraq (Mar. 18, 2003), reprinted in Colin Warbrick \& Dominic McGoldrick, Current Developments: The Use of Force Against Iraq, 52 INT'L \& COMP. L.Q. 811 (2003) (statement by U.K. AttorneyGeneral Lord Goldsmith in answer to a parliamentary question) [hereinafter "UK AttorneyGeneral Analysis"]. Although Spain did not contribute troops to the invasion, as a Security Council member it supported the legal theory advanced by the United States and its allies. See UN Doc. S/PV.4721, at 15-16 (Mar. 19, 2003). For Poland, which was not a member of the Security Council but did contribute forces, see UN Doc. S/PV.4726 at 24-25 (Mar. 26, 2003). 
The U.S. decision not to adopt a legal doctrine of preemptive self-defense, and instead to adopt an alternative legal theory, was a very welcome development for maintaining public world order. Invoking a legal doctrine of preemptive self-defense could have invited an unraveling of norms on the use of force by creating a precedent for action by any number states who purport to be threatened by acts of its neighbors that might occur in years hence. Had the United States relied on preemptive self-defense as its theory for invading Iraq, there is no easy answer why, as a legal matter, India could not invade Pakistan if India feels threatened by the potential future use of Pakistan's nuclear capability. By contrast, in emphasizing the myriad resolutions of the Security Council enacted to deal with Iraq, the United States was able to contain the precedent set by its invasion; in principle, the U.S. legal theory serves as a precedent only for future circumstances where an open-ended use of force authorization is issued by the Security Council and then stayed by a cease-fire resolution.

This article demonstrates, however, that the legal theory actually deployed by the United States is not persuasive. The text of Resolution 678, and those resolutions that followed, along with the associated negotiating history and subsequent practice, individually and collectively demonstrate that the United States and its allies did not have Security Council authorization in March 2003 to invade Iraq. Moreover, regardless of whether one regards the U.S. legal theory as persuasive, the complexity of the theory, its reliance on decisions of the Security Council taken years earlier to address different circumstances, and the clear resistance of a majority of Security Council members in March 2003 to the deployment of force against Iraq, combined to strip the invasion of Iraq of the collective legitimacy sought by the United States.

Nevertheless, the United States did invade Iraq, which raises serious questions about the 
efficacy of international norms on the use of force and the utility of the Security Council. If the United States proceeded without authority under international law, then what good is international law? If the United States proceeded in the face of opposition of the UN Security Council, then what good is the Security Council? This article argues that international law and international institutions played a very important role in the events leading up to the invasion of Iraq, both as a means for discourse among relevant actors within the United States, and as a means for mediating a struggle for power between the United States and other members of the global community. Indeed, despite the popular perception that the United States has abandoned the Security Council and, more generally, flouted the norms of the UN Charter, the approach taken by the United States in 2003, as well as certain repercussions to the United States from failing to obtain express Security Council authorization, may presage an enduring U.S. engagement with the United Nations.

Part II of this article briefly recounts the legal basis advanced by the United States. Part III critiques that basis by reviewing the language and background of the underlying Security Council resolutions, and the subsequent practice of the Security Council with respect to those resolutions. While there are arguments to be made in support of the U.S. legal theory, the theory is not persuasive in the context of the invasion of 2003. Part III further suggests that the invasion may represent the "final straw" in decades of stretching the UN Charter to cover actions by the major powers in a manner not expressly contemplated in Chapter VII. Part IV considers whether the invasion of Iraq, if not done under UN authority, demonstrates the futility of international rules on the use of force and the ineffectiveness of the UN Security Council.

\section{THE ASSERTED LEGAL BASIS FOR THE INVASION}


The legal basis for the invasion advanced by the United States, as well as by its allies, can be described as follows. ${ }^{11}$ First, in order to address Iraq's invasion of Kuwait of August 1990, the Security Council adopted Resolution 678 in November 1990, which authorized UN Member States to "use all necessary means" to uphold Security Council resolutions relating to Iraq and to "restore international peace and security in the area."

Second, after Iraqi forces were expelled from Kuwait, the Security Council adopted a "ceasefire" resolution—Resolution $687^{12}$ —in April 1991, which "imposed a series of obligations on Iraq, including, most importantly, extensive disarmament obligations, that were conditions of the ceasefire established under it." ${ }^{\text {13 }}$ Resolution 687 suspended the authorization to use force against Iraq, but did not terminate such authorization.

Third, Iraq "materially breached" its disarmament obligations by failing to disclose,

${ }^{11}$ The best U.S. government statement of the legal theory appears in the U.S. government's communication to the Security Council at the commencement of the invasion. See Letter dated 20 March 2003, supra note 8.

${ }^{12}$ SC Res. 687 (Apr. 3, 1991).

${ }^{13}$ See UN Doc. S/2003/351, supra note 8. 
discontinue, and destroy WMD programs. The Security Council recognized that Iraq was in "material breach" of its obligations on several occasions, including in October 2002 when it unanimously adopted Resolution 1441. That resolution gave Iraq "a final opportunity to comply with its disarmament obligations" and warned Iraq of "serious consequences" if it failed to do so. ${ }^{14}$

${ }^{14}$ SC Res. 1441 (Nov. 8, 2002). For background leading up to the resolution, see Sean D. Murphy, Contemporary Practice of the United States Relating to International Law, 96 AM. J. INT'L L. 956 (2002). 
Fourth, according to the U.S. legal theory, a material breach of Resolution 687 "removes the basis of the ceasefire and revives the authority to use force under resolution 678 (1990)."15 The ability for such revival of the authorization to use force may be seen in prior Security Council practice. Thus, in January 1993, the Security Council recognized that a material breach by Iraq revives the authority to use force, when it considered the authority for the United States and the United Kingdom to use military force against Iraq at that time.

Fifth, the use of force in March 2003 was necessary given Iraq's non-compliance over an extended period of time. Such action was also necessary to defend the United States and the international community from the threat posed by Iraq and to restore international peace and security in the area.

\section{AsSEssment of the Asserted U.S. Legal Basis}

On its face, the asserted legal basis for the invasion of Iraq seems plausible. The Security Council authorized a U.S.-led coalition to wage war on Iraq in 1991. That war ended with an agreement that Iraq would eliminate certain weapons of mass destruction. Iraq failed to do so from 1991 to 2003 . Therefore, the prior authorization, having lain dormant, is reawakened so as to allow a new U.S.-led coalition to disarm Iraq.

\footnotetext{
${ }^{15}$ See UN Doc. S/2003/351, supra note 8.
} 
The 1991 war with Iraq and the post-war conditions imposed on Iraq, however, occurred within the ambit of numerous Security Council resolutions. A close reading of those resolutions, the circumstances surrounding their adoption, and the subsequent practice of the Security Council with respect to those resolutions leads to the conclusion that the U.S. legal theory is wrong. ${ }^{16}$

\footnotetext{
${ }^{16}$ The International Court of Justice has provided some guidance on how to approach interpreting Security Council resolutions. In considering whether a Security Council resolution falls within the scope of UN Charter Article 25 - which provides that states must carry out "decisions" of the Security Council - the International Court stated:

The language of a resolution of the Security Council should be carefully analyzed before a conclusion can be made as to its binding effect. In view of the nature of the powers under Article 25, the question whether they have been in fact exercised is to be determined in each case, having regard to the terms of the resolution to be interpreted, the discussions leading to it, the Charter provisions invoked and, in general, all circumstances that might assist in determining the legal consequences of the resolution of the Security Council.
}

Legal Consequences for States of the Continued Presence of South Africa in Namibia (South West Africa) Notwithstanding Security Council Resolution 276 (1970), Advisory Opinion, 1971 ICJ REP. 16, 53 (June 21) [hereinafter Namibia case]; see Michael C. Wood, The Interpretation of Security Council Resolutions, 2 MAX Planck Y.B. OF UN LAw 73, 79 (1998) ("the great majority [of Security Council resolutions] deal with a particular situation or dispute. In such cases it is necessary to have as full a knowledge as possible of the political background and of the whole of the Council's involvement, both prior to and after the adoption of the resolution under consideration."). When interpreting Security Council resolutions, resort is often made to interpretive statements captured in the verbatim record of the meeting at which the resolution was adopted, whether made before or after the vote. See, e.g., Prosecutor v. Dusko Tadi_a/k/a/ "Dule", Decision on the Defence Motion for Interlocutory Appeal on Jurisdiction, 2 October 1995, International Tribunal for the Prosecution of Persons Responsible for Serious Violations of International Humanitarian Law in the Former Yugoslavia since 1991, Case No. IT-94-1-AR72, at paras. 75, 88, \& 143,105 INT'L L. REP. 419, at 493, 501-2, 526 [hereinafter Tadi_Decision]; 1962 UN JURID. Y.B. 241 (UN legal counsel relying on intention of framers of Security Council resolution 169, paragraph 4, regarding detention of mercenaries by the United Nations in the Congo); Wood, supra note 16, at 93-94.

This approach to interpreting Security Council resolutions has some parallels in the accepted approach to interpreting treaties, where in the first instance the ordinary meaning of the treaty, in context, is considered. Treaty interpretation, however, calls for recourse to the preparatory work of the treaty (i.e., the negotiating record) only where the initial interpretation leads to an ambiguous or obscure meaning, or to an absurd or unreasonable result. See Vienna 
Convention on the Law of Treaties, May 23, 1969, arts. 31 \& 32, 1155 U.N.T.S. 331, 340, 8 I.L.M. 679, 692 (hereinafter "VCLT"). Applying other aspects of treaty law to Security Council resolutions should also be approached with caution. See infra note 97.

The VCLT entered into force in 1980 and has been ratified by approximately 100 states. Its authoritative character as law, even for states not party to it, derives from the fact that it is now generally accepted that most of its provisions are declaratory of the customary international law of treaties. Although the United States has not become a party to the VCLT, the United States regards the substantive provisions of the VCLT as reflective of customary international law on the subject. See S. EXEC. Doc. L., 92nd Cong, 1st Sess. at 1(1971); 1 AMERICAN LAW Institute, Restatement of the Foreign RELATIONS LAW OF THE United StATES (ThiRd), pt. III, intro. note (1987). 


\section{A. What did Resolution 678 Authorize?}

On the U.S. interpretation, Resolution 678 authorized the use of force for a material breach of Resolution 687. There are certain aspects of Resolution 678, however, suggesting that such an interpretation is unpersuasive. Resolution 678 begins by listing in its preamble the ten resolutions passed by the Security Council after Iraq's invasion of Kuwait, beginning with Resolution 660. The first two operative paragraphs of Resolution 678 then state that the Security Council:

1. Demands that Iraq comply fully with resolution 660 (1990) and all subsequent relevant resolutions and decides, while maintaining all its decisions, to allow Iraq one final opportunity, as a pause of goodwill, to do so;

2. Authorizes Member States cooperating with the Government of Kuwait, unless Iraq on or before 15 January 1991 fully implements, as set forth in paragraph 1 above, the foregoing resolutions, to use all necessary means to uphold and implement Security Council resolution 660 (1990) and all subsequent relevant resolutions and to restore international 
peace and security in the area. ${ }^{17}$

${ }^{17}$ SC Res. 678, paras. 1-2 (Nov. 29, 1990). The phrase "all necessary means" or "all necessary measures" has become a synonym in the Security Council lexicon for the authorization to use military force. 
The structure of Resolution 678 suggests that the resolution is focused on Iraqi compliance with the Security Council's resolutions adopted after Iraq's invasion of Kuwait but before the date of Resolution 678 itself, which was November 29, 1990. The phrase "all subsequent relevant resolutions" in paragraph one appears to be a reference back to the ten resolutions specified in the preamble. ${ }^{18}$ Further, the authorization in paragraph two only becomes effective if by January 16 Iraq fails to comply with such resolutions. In other words, had Iraq complied with the obligations set forth under those ten resolutions-which related to Iraq's withdrawal from Kuwait, return of Kuwaiti nationals and property, and other matters, but which did not relate to weapons of mass destruction — on or before January 15, 1991, then the authorization contained in paragraph two would not be effective. Given that Iraq could not possibly comply by January 16 with resolutions that did not exist as of that date, the only reasonable interpretation of the language is that "all subsequent resolutions" refers to the ten resolutions existing at the time Resolution 678 was adopted, and not resolutions thereafter. ${ }^{19}$ Indeed, taken at face value, the U.S. interpretation presumably

${ }^{18} \mathrm{~A}$ counter-argument to this point would note that the preamble of Resolution 678 also contains a reference to "resolution 660 (1990) and the above-mentioned subsequent relevant resolutions" (emphasis added). By failing to repeat this formulation in operative paragraph one, it might be argued that a different meaning was intended, one that covered resolutions extending past Resolution 678. The counter-argument is weak, however, since paragraph one can just as easily be viewed as a reference back to both preambular clauses, and thus as restricting paragraph one to resolutions preceding Resolution 678. Accord Christian Schaller, Massenvernichtungswaffen und Präventivkrieg-Möglichkeiten der Rechtfertigung einer militärischen Intervention im Irak aus völkerrechtlicher Sicht, 62 ZEITSCHRIFT FÜR AUSLÄNDISCHES ÖFFENTLICHES RECHT UND VÖLKERRECHT 641, 646 (2002).

${ }^{19}$ Accord Guido den Dekker \& Ramses A. Wessel, Military Enforcement of Arms Control in Iraq, 11 LeIDEN J. INT’L L. 497, 504 (1998); Catherine Denis, La Résolution 678 (1990) Peut-Elle Légitimer les Actions Armées Menées Contre l'Iraq Postérieurement à l'Adoption de la Résolution 687 (1991)?, REVUE BELGE DE DROIT INT'L 485, 492 (1998); Rainer Hofmann, International Law and the Use of Military Force Against Iraq, 45 GERMAN Y.B. INT'L L. 10, 17 (2002); Nico Krisch, Unilateral Enforcement of the Collective Will: Kosovo, Iraq, and 
would authorize the use of force in perpetuity to uphold any Security Council resolution enacted under Chapter VII relating to Iraq, absent a further Security Council resolution terminating the authorization contained in Resolution 678. Such an interpretation is inconsistent with the carefulness with which the Security Council acted in authorizing the use of force in Resolution 678, whereby Iraq was provided "one final opportunity" to take specific actions that would forestall the resort to force. As such, the interpretation is not tenable.

the Security Council, 3 MaX Planck Y.B. of UN Law 59, 69 (1999); Dietrich Murswieck, Die amerikanische Präventivkriegsstrategie und das Völkerrecht, 14 NEUE JURISTISCHE WOCHENSCHRIFT 1014, 1015-16 (2003); Schaller, supra note 18, at 646; Nigel D. White \& Robert Cryer, Unilateral Enforcement of Resolution 687: A Threat Too Far?, 29 CAL. W. INT'L L.J. 243, 272 (1999); Pål Wrange, The American and British Bombings of Iraq and International Law, 39 Sandinavian Studies IN Law 491, 496, 500 (2000); Rex J. Zedalis, An Analysis of Some of the Principal Legal Questions Relating to U.N. Weapons Inspections in Iraq, 67 NORDIC J. INT'L L. 249, 258 (1998). 
Paragraph two, of course, speaks not just of using force to uphold subsequent Security Council resolutions, but also "to restore international peace and security in the area." ${ }^{20}$ The U.S. legal theory would rely on this language to say that since Iraq failed to comply with the relevant resolutions prior to January 16 , the use of force was authorized both to uphold those resolutions and to do more — to go beyond them so as to restore peace and security in the region. Thus, if Resolution 687 is viewed as setting the terms for what was necessary to restore peace and security in the region,

${ }^{20}$ Similar language appeared in the Security Council's 1950 recommendation that states give assistance to the Republic of Korea "to repel the armed attack [of North Korea] and to restore international peace and security in the area." SC Res. 83 (June 27, 1950). The interpretation placed on that language by the Security Council is unclear. On the one hand, the preceding resolution, SC Res. 82 (June 25, 1950), simply called for the cessation of hostilities and for North Korea to withdraw its forces to the thirty-eighth parallel, so the "restore" language might have been intended simply to enforce that request. See LELAND M. GOODRICH, KorEA: A StUdy OF U.S. Policy IN THE UNITED NATIONS 113 (1956). If so, the "restore" language is narrow in scope.

On the other hand, a resolution subsequently adopted by the General Assembly, GA Res. 376 (V) (Oct. 7, 1950), might be viewed as interpreting that language far more broadly. After the Soviet Union resumed participation in Security Council discussions of the Korea situation, the Soviet veto prevented any further Security Council resolutions, and so the matter was taken up by the General Assembly. In resolution 376, the General Assembly confirmed the authority of the "United Nations command" to destroy North Korean forces north of that parallel, recommended that "all appropriate steps be taken to ensure conditions of stability throughout Korea," and recommended that "all constituent acts be taken, including the holding of elections, under the auspices of the United Nations, for the establishment of a unified, independent and democratic government in the sovereign State of Korea."

The breadth of the General Assembly's interpretation may have been a function of the radical change on the ground in Korea from June to October, in which UN forces were pressing North Korean forces in disarray northward, and in which the capture of the entire peninsula seemed within grasp. When the military situation then changed again, with the threat of Communist Chinese intervention in Korea and a possible widening of the conflict, the General Assembly passed a resolution favoring a cease-fire. GA Res. 384 (V) (Dec. 14, 1950). As such, that resolution might be viewed as a General Assembly interpretation of the Security Council's authorization to use force "to restore peace and security in the area" as being restricted to repelling aggression, leaving to political negotiation the possibility of broader measures, such as Korean unification. See Leland M. GoOdRICH \& ANNE P. SimOnS, THE United NATIONS AND the Maintenance of International Peace AND SeCurity 468-70, 497-98 (1955). 
then the use of force authorization carried forward to the upholding of Resolution 687, including compliance with the WMD regime. ${ }^{21}$ This approach is a more tenable interpretation of Resolution 678, since some content must be given to the "restore" language and that content must be something

${ }^{21}$ Accord D.A. Leurdijk \& R.C.R. Siekmann, De rechtsbasis voor militaire actie tegen Irak, 52 DE INTERNATIONAL SPECTATOR 208, 208-212 (1998). 
different than upholding Security Council resolutions existing as of November $1990 .{ }^{22}$

${ }^{22} \mathrm{See}$ Constitution of the Maritime Safety Committee of the Inter-Governmental Maritime Consultative Organization, Advisory Opinion, 1960 ICJ REP. 150, 160 (June 8) [hereinafter IMCO case] (finding that the whole of the text of a provision in the IMCO Constitution must be presumed to have some significance, and rejecting an interpretation which rendered part of it redundant). In the law of international organizations, this rule is sometimes referred to as "la règle de l'effet utile." But see Denis, supra note 19, at 495; Wrange, supra note 19, at 496 (interpreting the "restore" language as relating solely to the resolutions existing at the time Resolution 678 was adopted); Nico Schrijver, The United Nations and the Use of Force: Comparing the Korea and Gulf Crises From a Legal Perspective, in LIBER AKKERMAN, IN- AND OutLaws IN WAR 255, 260 (P.J. van Krieken \& Ch. O. Pannenborg eds., 1992) (interpreting the "restore" language as simply a general confirmation that the coalition's actions had to be carried out in line with UN purposes and principles). 
There is, however, a far more plausible interpretation, which is that the "restore" language was intended to provide the coalition in early 1991 with considerable leeway in carrying out "Operation Desert Storm", including operations that were designed not just to compel Iraq to withdraw from Kuwait, but also those aimed at the broader threat of the regime of Saddam Hussein to Iraq's neighbors in the region. Thus, when expelling Iraqi military forces from Kuwait and securing Kuwait's border, the 1990-91 coalition found it necessary to cross into and occupy a swath of territory in southern Iraq as a buffer zone. Had the "restore" language not existed, then the crossing of military forces into Iraq would have been outside the scope of Resolution 678, since none of the ten preceding resolutions ordered Iraq to allow such a buffer zone. ${ }^{23}$ Moreover, and with particular relevance to the invasion of Iraq in 2003, the "restore" language could properly be interpreted as allowing Operation Desert Storm to include operations in 1991 to destroy Iraq's WMD infrastructure, on grounds that the WMD threatened Iraq's neighbors. Yet once Operation Desert Storm ended, and a new regime was developed in Resolution 687 to address the "restoration of peace and security in the region," the "restore" language of Resolution 678 is best seen as having

${ }^{23}$ In April 1991, as part of Resolution 687, a smaller demilitarized zone, comprising territory on both sides of the Iraq-Kuwait border, was established and patrolled by the UN IraqKuwait Observer Mission (UNIKOM). See SC Res. 687, para. 5 (Apr. 3, 1991). 
run its course. ${ }^{24}$

${ }^{24}$ See, e.g., SC Res. 707, pmbl. (Aug. 15, 1991) (characterizing Resolution 687 as the resolution "which established a cease-fire and provided the conditions essential to the restoration of peace and security in the region."). 
But why should the "restore" language necessarily be tied to the activities of Operation Desert Storm; why not stretch it to include any future efforts to restore peace and security in the region? One reason is that the major decision-makers at the time did not place such an interpretation on Resolution 678. Indeed, a mantra of the administration of George H.W. Bush was that U.S. forces in March 1991 could not go all the way to Baghdad in part because they lacked UN authorization to do so. ${ }^{25}$ The phrase is not "establish peace and security" or even "maintain peace and security" but, rather, "restore peace and security," a phrase that connotes the intention to reestablish a situation ex ante, ${ }^{26}$ not to create a new situation involving new governmental structures. ${ }^{27}$ Such

${ }^{25}$ See, e.g., JAMES A. BAKer, III, The Politics OF DiPlomaCy 436 (1995). In his memoire, the U.S. Secretary of State asserts:

To this day, controversy endures over whether coalition forces should have continued their offensive all the way to Baghdad and toppled Saddam's regime. I believe this idea as nonsensical now as it was then, and not merely for the legalistic reason that the U.N. resolutions did not authorize coalition forces to undertake anything beyond the liberation of Kuwait.

See also Jules Lobel \& Michael Ratner, Bypassing the Security Council: Ambiguous Authorizations to Use Force, Cease-Fires and the Iraqi Inspection Regime, 93 AM. J. INT'L L. 124, 140 (1999) (citing to Bush administration officials testimony to the Congress); Jochen Abr. Frowein, Unilateral Interpretation of Security Council Resolutions-a Threat to Collective Security?, in LiBer AMICORUM GÜNTHER JAENICKE-Zum 85. GeBRUTSTAG 97, 101-02 (Volkmar Götz et al. eds., 1998) ("This seems to have been the final evaluation by most members of the Security Council."). The UN legal counsel also took the view that Resolution 678 would not support coalition actions to eliminate Iraq's military capability or oust its leadership. See John F. Murphy, Force and Arms, in 1 United NATIONS Legal Order 247, 287 (Oscar Schachter \& Christopher C. Joyner eds., 1995).

${ }^{26}$ See Hofmann, supra note 19, at 17; Schaller, supra note 18, at 648-49. In considering what prior situation of "peace and security" was being "restored", reference should be made to the preamble of the first resolution, Resolution 660, where the Security Council determined "that there exists a breach of international peace and security as regards the Iraqi invasion of Kuwait." SC Res. 660, pmbl. (Aug. 2, 1990). Reversing the effects of that invasion appears to be the principal focus of the concept of restoring "peace and security." See Schaller, supra note 18, at 648-49 (arguing that the entirety of Resolution 678 points toward the goal of restoring Kuwaiti 
reasoning is even more compelling with respect to the invasion and occupation of Iraq thirteen years after its invasion of Kuwait, all for the purpose of toppling a regime that failed to comply with a weapons inspection regime that did not even exist when Resolution 678 was adopted.

sovereignty and independence, and that the authorization to restore peace and security must be seen in congruence with that goal).

${ }^{27}$ See Wrange, supra note 19, at 497. 
A second reason is that the U.S. interpretation leads to an even more extreme outcome than arises above with respect to the "subsequent resolutions" language. For if Resolution 678 authorizes a use of military force indefinitely to restore any "international peace and security in the area," then where does the authorization end? If current efforts to set up a post-Hussein Iraqi government fail in, say, ten years, leading to a civil war, is Resolution 678 still capable of supporting a use of force by outside states? Could Iran invoke such authority to intervene in Iraq? Indeed, the U.S. interpretation need not even be bounded by Iraq. If the United States were to decide that "international peace and security in the area" required intervention in Syria (perhaps because it was harboring fleeing Baath officials) or intervention in Iran (perhaps because Iran was supporting Shiites in Iraq), then presumably Resolution 678 could be stretched to authorize such invasions. Yet, such a broad interpretation of Resolution 678 clearly was not envisaged in November 1990 and cannot be sustained. ${ }^{28}$ Resolution 678 is an exception to the general and fundamental norm

${ }^{28}$ Accord Dekker \& Wessel, supra note 19, at 507-08 (arguing that "it can never have been the intention of the (indeed broadly formulated) provision in Resolution 678 to give an unconditional, unlimited, and unending authorisation to use military force."). Moreover, if the Security Council had authorized such an open-ended use of military force, the Council's action may well have exceeded its authority under UN law by abandoning its core function. Catherine Denis argues that

si le Conseil de sécurité adoptait une résolution par laquelle il autorise des États à recourir à law force de façon indéterminée ratione temporis ou ratione materiae, d'une part, ce dernier abandonnerait les responsabilités qui lui ont été conférées par la Charte puisqu'il n'exercerait plus de contrôle sur le ou les actions armées entreprise(s) et, de l'autre, il irait à l'encontre du principe de l'interdiction de l'emploi de la force dans les relations internationales en permettant ainsi que, dans certains cas, les États soient en situation de conflit permanent.

Denis, supra note 19, at 519; see also DANESH SAROOSHI, THE UNITED NATIONS AND THE DeVElopment of COLlective SECURITY 179-80 (1999); Schaller, supra note 18, at 647-48. For a broader, but related, discussion of the various problems in delegating UN authority under Chapter VII to member states, see GEORG Troost, DIE AUTORISIERUNG VON UN- 
expressed in UN Charter Article 2(4) prohibiting the use of force by a state against another state. As an exception to the general rule, Resolution 678 should be narrowly construed. ${ }^{29}$ The most plausible interpretation is that the "restore" language is tied to uses of force reasonably related to upholding the ten Security Council resolutions set forth in the preamble to Resolution 678.

MitGLIEDSTAATEN ZUR DURCHFUHRUNG MILITARISCHER ZWANGSMASSNAHMEN DES SICHERHEITSRATES IN RECHT UND PRAXIS DER VEREINTEN NATIONEN (1997).

${ }^{29}$ Denis, supra note 19, at 494; Lobel \& Ratner, supra note 25, at 129. 
Finally, the second paragraph of Resolution 678 only authorizes the use of force by states "cooperating with the Government of Kuwait." Having been expelled from its country in 1990, the government of Kuwait was extremely vocal and enthusiastic about the deployment of military force against Iraq to restore the Kuwaiti government's authority, as envisaged in Resolution $661 .^{30}$ In 1991, at the advent of Operation Desert Storm, the coalition was careful to ensure that Kuwait communicated to the Security Council that it had requested the coalition states to assist it in repelling Iraqi forces from Kuwait. ${ }^{31}$ Further, the coalition forces were careful to note that they had been requested by Kuwait to use force against Iraq. ${ }^{32}$ In 2003, however, no such communication was sent by Kuwait to the Security Council, nor did Australia, the United Kingdom, or the United States indicate in their communications to the United Nations either that Kuwait had requested assistance or that those states were acting in cooperation with Kuwait. Kuwait certainly allowed the U.S.-led forces to use Kuwaiti territory to launch operations against Iraq and, in that sense, "cooperated" with the invasion in a very critical sense. ${ }^{33}$ On the other hand, in a presentation to the Security Council,

${ }^{30}$ See SC Res. 661, para. 2 (Aug. 6, 1990).

${ }^{31}$ See Letter Dated 17 January 1991 from the Permanent Representative of Kuwait to the United Nations Addressed to the President of the Security Council, UN Doc. S/22094 (Jan. 17, 1991) (reporting that "Kuwaiti forces are cooperating with the forces of fraternal and friendly States which are equally determined to end the obdurate Iraqi occupation.").

${ }^{32}$ Letter Dated 17 January 1991 from the Permanent Representative of the United States of America to the United Nations Addressed to the President of the Security Council, UN Doc. S/22090 (Jan. 17, 1991) (stating that the United States "had deployed military forces to the Persian Gulf region in response to requests from Governments in the region, including Kuwait and Saudi Arabia" and that U.S. and coalition forces "co-operating with the Government of Kuwait" had initiated military action against Iraq).

${ }_{33}^{33}$ See, e.g., Vernon Loeb \& Bradley Graham, Rapid Buildup in Gulf on Horizon, WASH. Post, Dec. 20, 2002, at A45; Patrick E. Tyler, U.S. and British Troops Push Into Iraq as Missiles Strike Baghdad Compound, N.Y. TIMES, Mar. 21, 2003, at A1. 
Kuwait distanced itself from the U.S.-led invasion, saying that "Kuwait reaffirms that it has not participated and will not participate in any military operation against Iraq and that all measures we are undertaking are aimed at protecting our security, safety and territorial integrity." 34 The absence of a request from Kuwait for assistance, when considered in the context of collective self-defense, would cast doubt on whether the conduct was truly undertaken as a matter of self-defense. ${ }^{35}$ Similarly, the lack of any Kuwaiti request for an invasion of Iraq and removal of the Iraqi regime

${ }^{34}$ UN Doc. S/PV.4726 at 14 (Mar. 26, 2003).

${ }^{35}$ See Military and Paramilitary Activities in and against Nicaragua (Nicar. v. U.S.), 1986 ICJ REP. 14, 105, para. 199 (Judgment of June 27). Some scholars subscribe to the view that Resolution 678 simply may have been a recognition of an inherent right of collective selfdefense and nothing more. See Oscar Schachter, United Nations Law in the Gulf Conflict, 85 AM. J. InT'L L. 452, 459-61 (1991); Eugene Rostow, Until What? Enforcement Action or Collective Self-Defense, 85 AM. J. InT’L L. 506 (1991); but see THOMAS M. FrANCK, RECOURSE to Force: State Action Against Threats And Armed Attacks 26 n. 19 (2002); White \& Cryer, supra note 16, at 270. If that view is correct, then the failure of the United States to base the 2003 invasion on assistance to Kuwait is even more telling. The United States, however, never expressly adopted that view of Resolution 678. 
in 2003 and its distancing of itself from those objectives, casts some doubt that the United States and its allies were "cooperating with the Government of Kuwait"-in the sense apparently meant by Resolution 678 - to achieve those objectives. ${ }^{36}$

B. Did Resolution 687 preserve the general authorization in Resolution $678 ?$

${ }^{36}$ Moreover, while in 1991 the United States was careful to report to the Security Council on actions undertaken pursuant to Resolution 678, no such reports were made in 2003. See, e.g., Letter Dated 5 March 1991 from the Permanent Representative of the United States of America to the United Nations Addressed to the President of the Security Council, UN Doc. S/22341 (Mar. 8, 1991); UN Doc. S/22090, supra note 32. 
By its terms, Resolution 687 of April 1991 neither expressly suspended nor expressly terminated Resolution 678. In the preamble of Resolution 687, the Security Council "recalls" Resolution 678 and further says that it is "[b]earing in mind its objective of restoring international peace and security in the area as set out in recent resolutions of the Security Council." Paragraph one of Resolution 687 then "affirms" all earlier resolutions relating to Iraq, including Resolution 678, "except as expressly changed below to achieve the goals of this resolution, including a formal cease-fire." After setting forth various provisions regarding the demarcation of the Iraq-Kuwait border, establishment of a demilitarized zone along that border, identification and destruction of weapons of mass destruction, compensation for loss, damage or injury from Iraq's invasion, and other matters, paragraph thirty-three of Resolution 687 declares that, "upon official notification by Iraq to the Secretary-General and to the Security Council of its acceptance of the provisions above, a formal cease-fire is effective between Iraq and Kuwait and the Member States cooperating with Kuwait in accordance with resolution 678 (1990). ${ }^{, 37}$ Iraq informed the United Nations of its acceptance of Resolution $687 .^{38}$ The president of the Security Council then advised Iraq that the Security Council had determined that the conditions established in paragraph thirty-three of Resolution 687 had been met. ${ }^{39}$

The U.S. legal theory is that Resolution 687 implicitly indicates that international peace and

${ }^{37}$ SC Res. 687, para. 33 (Apr. 3, 1991).

${ }^{38}$ See Identical Letters Dated 6 April 1991 from the Permanent Representative of Iraq to the United Nations Addressed Respectively to the Secretary-General and the President of the Security Council, UN Doc. S/22456 (Apr. 6, 1991) (concluding that Iraq "has no choice but to accept this resolution").

39 See Letter Dated 11 April 1991 from the President of the Security Council to the Permanent Representative of Iraq to the United Nations, UN Doc. S/22485 (Apr. 11, 1991). 
security has not yet been restored to the area, that the provisions of Resolution 687 must be fulfilled before such restoration occurs, and that the Resolution 678 authorization to use force generally remains viable until such conditions are fulfilled. There are three principal problems with this interpretation.

First, the interpretation does not take account of Resolution 686, which is sometimes referred to as the "provisional cease-fire resolution." ${ }^{40}$ After six weeks of an air and ground campaign against Iraq in January-February 1991, Iraq informed the United Nations on February 27 that it agreed to comply fully with the Security Council's resolutions. ${ }^{41}$ President George Bush ordered a suspension of offensive combat operations effective February 28. Shortly thereafter, on March 2, the Security Council adopted Resolution 686 as a prelude to the much more robust Resolution 687 of April 2.

The Security Council said in Resolution 686 that it was "[u]nderlining the importance of Iraq taking the necessary measures which would permit a definitive end to the hostilities" (emphasis added). In paragraphs two and three of the resolution, the Security Council listed eight measures that Iraq must implement: (1) rescind the purported annexation of Kuwait; (2) accept in principle liability for loss, damage or injury from the invasion of Kuwait; (3) release, or return the remains, of all detained foreign nationals; (4) begin to return all Kuwaiti property; (5) cease hostile or provocative actions against other states, including missile attacks and flight of combat aircraft; (6) designate military commanders to arrange for military aspects of a cessation of hostilities; (7) release, or return

${ }^{40}$ On the need to read together a series of Security Council resolutions relating to a situation so as to ascertain their "combined and cumulative effect," see Namibia case, supra note 16 , at 51 .

${ }^{41}$ See Letter Dated 27 February 1991 from the Permanent Representative of Iraq to the United Nations Addressed to the Secretary-General, UN Doc. S/22276 (Feb. 27, 1991). 
the remains, of prisoners of war; and (8) help identify Iraqi mines, booby traps and other explosives, as well as any chemical and biological weapons, located in Kuwait, in areas of Iraq occupied by the coalition, and in the adjacent waters. ${ }^{42}$ Then, in paragraph four, the Security Council explicitly addressed the continuing viability of Resolution 678, saying that it "[r]ecognizes that during the period required for Iraq to comply with paragraphs 2 and 3 above, the provisions of paragraph 2 of resolution 678 (1990) remain valid." In the final operative paragraph of the resolution, the Security Council looked forward to "the rapid establishment of a definitive end to the hostilities."43

${ }^{42}$ SC Res. 686, paras. 2-3 (Mar. 2, 1991).

${ }^{43} I d$., para. 8 (emphasis added). 
Thus, while Resolution 687 contained no express language regarding the termination of Resolution 678, Resolution 686 did contain such language. By the terms of Resolution 686, Resolution 678 would "remain valid" for the period required for Iraq to comply with the eight measures listed above. The language does not simply recognize that Resolution 678 remains valid, nor that it generally remains valid, including for the time period associated with the eight measures. Rather, the language clearly ties the continuing validity of Resolution 678 to the period required for compliance with the eight measures. ${ }^{44}$

In the debate over Resolution 686, the U.S. representative confirmed this understanding. He asserted that, with the liberation of Kuwait, the Security Council was now turning its attention to the requirements for the restoration of peace and security in the area, as contemplated in Resolution 678.

In this resolution [Resolution 686], the Council puts forth the immediate requirements ... Until it is clear that Iraq has complied with these requirements, the provisions of resolution 678 (1990) authorizing Kuwait and those cooperating with Kuwait to use all necessary means to ensure Iraqi compliance with the United Nations resolutions

${ }^{44}$ See Dekker \& Wessel, supra note 19, at 504; Denis, supra note 19, at 497; Wrange, supra note 19, at 497. 
clearly will remain in effect. ${ }^{45}$

Security Council member Yemen also confirmed this understanding in the course of objecting to it:

${ }^{45}$ See IraQ And Kuwait: The Hostilities And Their Aftermath 94 (M. Weller ed., 1993) (emphasis added). 
$[\mathrm{P}]$ aragraph 4 of the draft resolution relates to the continued use of force. Although we heard during the informal meetings that such force would be used only for specific purposes, we find it strange that there is still talk about the use of force now that Iraqi troops have been completely withdrawn from Kuwait and the purposes of resolution 660 (1990) have been implemented. We were told that force would be used only for the secondary reasons indicated in the resolution. But how can force be used in connection with a difference about legal questions, or if Iraq does not live up to one of the paragraphs of the resolution? Does this mean that force will be used to compel Iraq to implement such a paragraph? We find this absolutely excessive and against the spirit of the United Nations resolutions. ${ }^{46}$

Similarly, the representative of China noted that Resolution 686 "extends the time limit during which resolution 678 (1990) remains effective. ${ }^{, 47}$ Ecuador, which voted in favor of the resolution, characterized paragraph four as a bridge to a permanent cease-fire resolution(s), at which point the authorization to use force would no longer be necessary. ${ }^{48}$ Other states, such as Cuba and Zimbabwe, expressed concerns about allowing a continuation of the use of force authorization as stated in Resolution 686, which implied that they believed the use of force authorization only remained in play by virtue of paragraph four of that resolution. ${ }^{49}$

${ }^{46}$ Id. at 94.

${ }^{47}$ Id. at 95 .

${ }^{48} I d$, at 100.

${ }^{49}$ See id. at 92 (Cuba) ("Having ended the illegal Iraqi occupation of the territory of Kuwait, and having ensured that it will regain its independence and territorial sovereignty, the Security Council must apparently once again relinquish its obligations and place them on the 
shoulders of some states ..."); 92-93 (Zimbabwe) (“[I]t is Zimbabwe's hope that a situation will not arise in which operative paragraph 4 of the draft resolution will be invoked to resume military operations in the area."). Cuba ultimately voted against the resolution, while China, India and Yemen abstained. 
Whatever meaning might be ascribed to Resolution 678 at the time that it was passed, that meaning must be regarded as altered by the language of Resolution 686, paragraph four. The most natural interpretation is that the use of force language in Resolution 678 remained valid for the period required for Iraq to comply with the eight specific measures and only for the purpose of enforcing those measures. ${ }^{50}$ In fact, force was used twice by coalition forces between the adoption of Resolution 686 and the adoption of Resolution 687, in both instances apparently in response to Iraqi breaches of its obligations under Resolution $686 .{ }^{51}$ If Resolution 678 only remained valid for enforcement of Resolution 686, then it did not remain valid for any other purposes, such as enforcing the disarmament provisions of Resolution 687 or, more broadly, restoring peace and

${ }^{50}$ See Schaller, supra note 18, at 650; but see Christine Gray, After the Ceasefire: Iraq, the Security Council and the Use of Force, 65 BRIT. Y.B. INT'L L. 135, 139-40 (1992) (suggesting that Resolution 686 preserved the authorization to use force in Resolution 678 for the purposes set forth in that resolution, but might not have extended such authorization to compliance with paragraphs two and three of Resolution 686); Helmut Freudenschuß, Between Unilateralism and Collective Security: Authorizations of the Use of Force by the UN Security Council, 5 EuR. J. INT'L L. 492, 499 (1994) (similar view by an Austrian representative to the Security Council in 1991-92).

${ }^{51}$ See R. Lavalle, The Law of the UN and the Use of Force, under the Relevant Security Council Resolutions of 1990 and 1991, to Resolve the Persian Gulf Crisis, 23 NETH. Y.B. INT'L L. 3, 52 (1992). 
security to the area.

An alternative interpretation - that failure to comply with those eight measures left Resolution 678 valid for any purposes within the scope of Resolution 678 as well as for enforcement of Resolution 686 - is possible, ${ }^{52}$ but ultimately unconvincing given the structure of Resolution 686. In Resolution 686, the Security Council underlined the importance of Iraq taking measures which would permit a definitive end to the hostilities, then set forth eight measures to be taken, and then said that Resolution 678 remained valid until those measures are completed. This structure suggests that Resolution 678 was now being confined to core demands associated with the prior Security Council resolutions that had not yet been fulfilled. ${ }^{53}$ Even less persuasive is the interpretation that must be placed on Resolution 686 if one adheres to the U.S. legal theory for the invasion of Iraq, which is that Resolution 678 remained valid regardless of whether Iraq complied with the eight demands.

Rather than using language "suspending” Resolution 678, the Security Council twice used language in Resolution 686 envisaging a "definitive end to the hostilities." Security Council was concerned not just with Iraqi compliance with the eight measures, but also with withdrawal of coalition forces from Iraqi territory. In both Resolutions 686 and 687, the Security Council affirmed the independence, sovereignty and territorial integrity of Iraq (as well as

\section{${ }^{52} I d$.}

${ }^{53}$ See IRAQ AND KUWAIT, supra note 45, at 98 (statement of U.K. representative to the Security Council) ("The requirements [Resolution 686] places on the Government of Iraq are not new ones. They flow from the resolutions we have adopted and from the statements previously made on behalf of the Governments assisting and cooperating with the Government of Kuwait."); Denis, supra note 19, at 497-99.

${ }^{54}$ SC Res. 678, pmbl. \& para. 8 (Nov. 29, 1990). 
Kuwait) and noted the intention of member states cooperating with Kuwait "to bring their military presence in Iraq to an end as soon as possible.",55

${ }^{55}$ SC Res. 686, pmbl. (Mar. 2, 1991); SC Res. 687, pmbl. (Apr. 3, 1991). 
On March 3, Iraq informed the Security Council that it "has agreed to fulfill its obligations under" Resolution $686{ }^{56}$ Shortly thereafter, Iraq rescinded its purported annexation of Kuwait in March $1991{ }^{57}$ Further, Iraq accepted in principle liability for loss, damage or injury from the invasion of Kuwait when it accepted Resolution $687 .{ }^{58}$ Iraq began the process of returning Kuwaiti property by identifying coins, bank notes, aircraft, and other property stolen from Kuwait, ${ }^{59}$ although

${ }^{56}$ See Letter Dated 3 March 1991 from the Permanent Representative of Iraq to the United Nations Addressed to the President of the Security Council, UN Doc. S/22320 (Mar. 3, 1991).

${ }^{57}$ See Identical Letters Dated 8 March 1991 from the Permanent Representative of Iraq to the United Nations Addressed Respectively to the Secretary-General and the President of the Security Council, UN Doc. S/22342 (Mar. 8, 1991) (transmitting the decision of the Revolution Command Council); Identical Letters Dated 21 March 1991 from the Permanent Representative of Iraq to the United Nations Addressed Respectively to the Secretary-General and the President of the Security Council, UN Doc. S/22370 (Mar. 21, 1991) (transmitting the official publication of the Command Council's decision).

${ }^{58}$ See UN Doc. S/22456, supra note 38.

59 See Identical Letters Dated 5 March 1991 from the Permanent Representative of Iraq to the United Nations Addressed Respectively to the Secretary-General and the President of the Security Council, UN Doc. S/22330 (Mar. 5, 1991) (agreeing to return Kuwaiti gold, paper currency, museum objects, and civilian aircraft seized after August 2, 1990 and asking for the procedures for doing so); Identical Letters Dated 18 March 1991 from the Permanent Representative of Iraq to the United Nations Addressed Respectively to the Secretary-General and the President of the Security Council, UN Doc. S/22355 (Mar. 18, 1991) (agreeing that the office of the UN secretary-general shall be entrusted with receipt and delivery of Kuwaiti property); Identical Letters Dated 18 March 1991 from the Permanent Representative of Iraq to the United Nations Addressed Respectively to the Secretary-General and the President of the Security Council, UN Doc. S/22356 (Mar. 18, 1991) (regarding museum artifacts); Identical Letters Dated 18 March 1991 from the Permanent Representative of Iraq to the United Nations Addressed Respectively to the Secretary-General and the President of the Security Council, UN Doc. S/22357 (Mar. 18, 1991) (regarding Kuwaiti civilian aircraft); Identical Letters Dated 19 March 1991 from the Permanent Representative of Iraq to the United Nations Addressed Respectively to the Secretary-General and the President of the Security Council, UN Doc. S/22360 (Mar. 19, 1991) (regarding Kuwaiti military aircraft); Identical Letters Dated 21 March 1991 from the Permanent Representative of Iraq to the United Nations Addressed Respectively to the Secretary-General and the President of the Security Council, UN Doc. S/22375 (Mar. 21, 
disputes remained about whether all such property had been returned. ${ }^{60}$ Iraq also began the process of returning all detained foreign nationals and POWs, or their remains, although here too some disputes remained about missing persons. ${ }^{61}$ At least initially, Iraq ceased hostile or provocative actions against other states, including missile attacks and flight of combat aircraft. Iraq designated military commanders to arrange for military aspects of the cessation of hostilities. Iraq provided information and assistance in identifying Iraqi mines and other weapons located in Kuwait, the area occupied by coalition forces, and adjacent waters.

Since disputes remain regarding some of these issues, Iraq has not fully complied with all these measures, even today. Yet if such measures remain to be fulfilled, and if Resolution 678 remains valid for the purpose of ensuring their fulfillment, then the focus should be on Iraq's noncompliance with these measures and whether force may be used to compel Iraq's compliance. The

1991) (regarding Kuwaiti coins and banknotes).

${ }^{60}$ See, e.g., Letter Dated 1 April 1991 from the Permanent Representative of Kuwait to the United Nations Addressed to the President of the Security Council, UN Doc. S/22433 (Apr. 2,1991 ) (identifying discrepancies in identified coins and banknotes).

${ }^{61}$ Indeed, the preamble of Resolution 687 itself notes that "despite the progress made in fulfilling the obligations of resolution 686 (1991), many Kuwaiti and third country nationals are still not accounted for and property remains unreturned." See also SC Res. 706, pmbl. (Aug. 15, 1991). 
U.S. theory does not focus on such non-compliance; rather, it focuses on non-compliance with the provisions of Resolution 687 concerning weapons of mass destruction. One of the measures contained within Resolution 686 concerns weapons of mass destruction in Iraq, but only in a narrow sense of weapons in areas of Iraq occupied by the 1990-91 coalition.

The second problem with the U.S. interpretation of Resolution 687 as merely suspending Resolution 678 is that it ignores the penalties expressly incorporated in Resolution 687 for noncompliance with the resolution. When Resolution 687 was drafted, there was concern that Iraq might not comply with the provisions for the destruction, removal or rendering harmless of its weapons of mass destruction. To address that concern, the Security Council could have repeated, but did not repeat, in Resolution 687 the same type of provision as appeared in Resolution 686 regarding the continuing validity of Resolution 678 pending Iraqi compliance with the disarmament provisions. ${ }^{62}$ Rather, the Security Council expressly provided for an alternative means of coercing compliance with Resolution 687. Paragraph twenty-two of the resolution provides that the economic sanctions imposed on Iraq during the 1990-91 crisis would remain in place until Security Council agreement that Iraq had complied with its disarmament obligations. ${ }^{63}$ Moreover, the sanctions would be reviewed by the Security Council every sixty days for the purpose of determining whether they

${ }^{62}$ See SAROOSHI, supra note 28, at 182; Wrange, supra note 19 , at 498, n. 28. Ian Johnstone, who served as an associate legal officer at the United Nations in 1991, asserts that "in a preliminary draft of Resolution 687, the authorization [to use force] was explicitly reaffirmed," but that such language was not retained in the final resolution so as to secure support from states who wanted "to nullify the authorization in Resolution 678 to use force." IAN JOHNSTONE, AfTERMATH OF THE GULF WAR: AN ASSESSMENT OF UN ACTION 39 (1994). Johnstone notes that "[w]hen Resolution 687 was drafted, it was politically impossible to secure an explicit authorization permitting further military action by the coalition states." Id. at 57.

${ }^{63}$ SC Res. 687, para. 22 (Apr. 3, 1991). 
should be reduced or lifted in light of Iraqi compliance ${ }^{64}$ Thus, the members of the Security Council affirmatively agreed that an Iraqi failure to meet its disarmament obligations would result in measures falling short of the use of force. As the U.S. representative to the United Nations stated when Resolution 687 was adopted:

${ }^{64}$ Id., para. 21; see also id., para 28. 
The resolution creates a dynamic and flexible process which links the removal of sanctions to the implementation of the resolution. This is the incentive to implement fully the resolution as soon as possible. Sanctions relating to foodstuffs and supplies for essential civilian needs are lifted at once, subject to certain procedural arrangements. Upon implementation of the provisions dealing with weapons of mass destruction and the compensation regime, the sanctions against Iraq's exports will also be lifted. ${ }^{65}$

Finally, paragraph 34 of the resolution states that the Security Council (not member states) shall "take such further steps as may be required for the implementation of the resolution and to secure peace and security in the area." ${ }^{, 66}$ Thus, the U.S. theory of an implicitly continuing viability of Resolution 678 to enforce the WMD provisions of Resolution 687 must fall in the face of an express penalty in that resolution for Iraqi non-compliance with its disarmament obligations, as well as the absence of language regarding Resolution 678 (such as existed in Resolution 686). ${ }^{67}$

${ }^{65}$ IRAQ AND KUWAIT, supra note 42, at 114 (emphasis added). Thereafter, the U.S. executive branch repeatedly reported to the Congress that sanctions were being maintained "[b]ecause of Iraq's failure to comply fully with United Nations Security Council resolutions." See, e.g., Message to the Congress Reporting on the National Emergency With Respect to Iraq, 1993 PUB. PAPERS 1307 (Aug. 2, 1993); see also Denis, supra note 19, at 506-507 (citing to Security Council presidential statements linking Iraqi compliance with its WMD obligations to maintenance of economic sanctions).

${ }^{66}$ SC Res. 687, para. 34 (Apr. 2, 1991); see Frowein, supra note 25, at 107; JOHNSTONE, supra note 62, at 40 ("A comparison of this language with paragraph 4 of Resolution 687 relating to the border suggests that once the cease-fire came into effect any 'further steps' (beyond economic sanctions) would have to be decided on by the Council as a whole, rather than by individual states acting under the authority of Resolution 678.").

${ }^{67}$ See, e.g., Wissenschaftliche Dienste Des Deutschen Bundestages, Fachbereich II, Reichweite der Resolutionen 678 (1990), 687 (1991) und 1441 (2002) des Sicherheitsrates der Vereinten Nationen, Doc. WF II-133/02 at 6 (Jan. 2, 2003) (study 
prepared by the German Federal Parliament's Research Service on the application of Security Council resolutions 678, 687, and 1441) [hereinafter "German Federal Parliament Research Service"]. The study concludes that the authorization contained in Resolution. 678 was expended with the liberation of Kuwait and that the option to continue such an authorization to enforce Resolution 687 was not pursued. The study also regards the high volume of Security Council resolutions and Security Council presidential statements subsequent to Resolution 687 as even further evidence of a completely changed legal environment-one in which Resolution 678 has no applicability. 
This point is reinforced by the fact that the possibility of using force to implement Resolution 687 was considered by the drafters of the resolution in the context of the demarcation of the Iraq-Kuwait boundary. In paragraph two, the Security Council demanded that Iraq and Kuwait respect the inviolability of the boundary, and the allocation of islands, that the two states had agreed upon in 1963. In paragraph four, the Security Council decided "to guarantee the inviolability of the above-mentioned international boundary and to take as appropriate all necessary measures to that end in accordance with the Charter of the United Nations" (emphasis added). ${ }^{68}$ Such language was sufficiently similar to Resolution 678 to worry some states about whether it constituted agreement by the Security Council that states could use force to ensure the sanctity of the boundary. Speaking to the members of the Security Council just before the vote was taken, India summarized the meaning of language as follows:

${ }^{68}$ SC Res. 687, para. 4 (Apr. 3, 1991); see SC Res. 773, para. 4 (Aug. 26, 1992); SC Res. 806, para. 1 (Feb. 5, 1993) (underlining this guarantee). 
As regards operative paragraph 4, it is India's understanding that it does not confer authority on any country to take a unilateral action under any of the previous resolutions of the Security Council. Rather, the sponsors have explained to us that in case of any threat or actual violation of the boundary in [the] future the Security Council will meet to take, as appropriate, all necessary measures in accordance with the Charter. ${ }^{69}$

${ }^{69}$ See IRAQ AND KUWAIT, supra note 42, at 113. 
No other Security Council member challenged or corrected this interpretation, including the United Kingdom and United States, both of whom spoke after India. ${ }^{70}$ In other words, the Security Council members did discuss whether a violation of Resolution 687 with respect to the inviolability of the boundary could lead to a use of force in the absence of further Security Council authorization, and the understanding reached was that further authorization would be needed. ${ }^{71}$ If that understanding is correct, then it reflects a belief at the time that Resolution 678 did not remain valid as a general matter for enforcing even serious breaches of Resolution 687. If it had remained valid, then India should have worried about much more than just paragraph four; it should have worried about the

${ }^{70}$ The one Security Council member who appears to have articulated a view that Resolution 687 preserves the use of force authorization in Resolution 678 was Yemen, which voted against Resolution 687 on that and other grounds. The Yemeni representative stated:

[I]t is well known that the draft resolution before us aims at the formal declaration of a cease-fire-only a cease-fire. This means that the state of war will continue between Iraq and the forces of the alliance until a definitive end is put to the military operations and hostilities, in accordance with paragraph 8 of resolution 686 (1991). But who will determine this? It will be left to the forces of the alliance.

$I d$. at 108 . Yet most members made statements recognizing that the resolution meant an end to the hostilities, in a manner that seemed to imply the end of the authorization to use force. See id. at 109. (statement by Zaire that with adoption of the resolution the Gulf region "will finally regain the lasting peace to which it has aspired"); $i d$. at 113 (statement of India that "we have consistently attached great importance to and called for the promulgation of a definitive, formal cease-fire so that the people of Iraq - as, indeed, the international community in general — can get going with normal life and State-to-State relations."); id. at 117 (statement of Russia that "[t]he crux of the resolution just adopted is to turn the temporary cessation of hostilities into a permanent cease-fire between Iraq and Kuwait after official notification by Iraq of its acceptance of the resolution."); $i d$. at 118 (statement of Ecuador that "it formally marks the end of the phase of hostilities in the Gulf"); id. at 122 ("Belgium particularly welcomes the fact that this official cessation of hostilities is the culmination of a long process designed to restore the rule of law, in accordance with the means laid down in the Charter.") Admittedly, no state expressly said that the ability to use force under Resolution 678 had terminated, but neither did any state assert that it had been preserved, as would be expected if that was the intention.

${ }^{71}$ See Freudenschuß, supra note 50, at 500-501. 
entire resolution serving as a platform for states using force against Iraq whenever a violation, perceived or real, might arise. Ultimately, the Iraqi movement of military forces in 1994 in the direction of the border of Kuwait resulted in the Security Council reaffirming Resolutions 678, 686, and 687, and "in particular paragraph 2 of resolution 678 (1990)", as a means of pressuring Iraq to withdraw its military units to their original position. ${ }^{72}$ No such language was ever used by the Security Council in reaction to Iraq's failure to abide by its disarmament obligations.

72 SC Res. 949, pmbl. (Oct. 15, 1994); see Denis, supra note 19, at 509-10 (arguing that Resolution 949 demonstrates that the use of force authorization in Resolution 678 was viewed as closely tied to the liberation of Kuwait and not to compliance with Resolution 687, and noting that the United States viewed Resolution 949, in part, as concerning a legitimate right of selfdefense). 
The third problem with the "revival" theory concerns the objectives for which the revived use of force may be used. If a material breach of Resolution 687 is the trigger for using force under the authority of resolution 678 , then presumably that use of force is limited to what is necessary and proportionate in addressing the material breach. ${ }^{73}$ Thus—assuming the "revival" theory is valid—an Iraqi failure to allow weapons inspectors to visit a particular site might result in a use of force to compel acceptance of those inspectors, or the Iraqi construction of a WMD site might be destroyed by a missile attack. Yet, by contrast, material breaches of that type would not seem to warrant a state or group of states invading and occupying Iraq, and toppling its government. During the 1990's, commentators who supported the "revival" theory would at times note that it could not be stretched to encompass an invasion. ${ }^{74}$ One can certainly imagine reaching a situation where material breaches

${ }^{73}$ Although the legal theory is cast in terms of "material breach" of Security Council resolutions, the resort to force in response to that breach is still governed by international rules applying to the use of force. It is generally accepted that customary international law requires that the use of force-whether based on self-defense or on authority of the Security Council under Chapter VII of the Charter-be necessary to address. and proportionate to, the threat that gave rise to the right to use force. See, e.g., 1 THE CHARTER OF THE UnITED NATIONS 753 (Bruno Simma, ed., 2d ed., 2002) (noting the language in UN Charter Article 42 that the Security Council may decide on forcible measures "as may be necessary" to maintain or restore international peace and security); see also Legality of the Threat or Use of Nuclear Weapons, 1996 ICJ Rep. 226, para. 41 (Advisory Opinion of July 8); Judith Gail Gardam, Proportionality and Force in International Law, 87 AM. J. INT'L L. 391, 391 (1993). Similarly, the rules relating to "counter-measures" under the law of state responsibility (which concern measures by one state against another state whose acts impair the international rights of the first state) call for such counter-measures to be proportionate, meaning "commensurate with the injury suffered, taking into account the gravity of the internationally wrongful act and the rights in question." See JAMES CRAWFORD, THE INTERNATIONAL LAW COMMISSION'S ARTIClES ON STATE RESPONSIBILITY: INTRODUCTION, TEXT, AND COMMENTARIES 294 (2002) (quoting Article 51 of the International Law Commission's articles on state responsibility); see also FRANCK, supra note 35, at 132-34 (asserting that UN practice offers some latitude for states to resort to forcible counter-measures, but that such acts are assessed in accordance with principles of necessity and proportionality).

${ }^{74}$ See, e.g., Joseph Murphy, De Jure War in the Gulf: Lex Specialis of Chapter VII 
of obligations under Resolution 687 were of such a magnitude that the only means for addressing them would be to oust the Iraqi government, but leaving to individual states the ability to determine that such a situation has been reached is inconsistent with the otherwise systematic engagement of the United Nations in the creation and monitoring of Iraq's WMD obligations. Moreover, invading and toppling the Iraqi government is not using force to compel compliance with Resolution $687 .^{75}$

Actions Prior to, During, and in the Aftermath of the United Nations War Against Iraq, 5 N.Y. INT'L L. REV. 71, 85 (1992) ("The military action should be limited to the destruction of any weapons, stocks of agents used in chemical and biological weapons, and all related subsystems and components, including all research, development, support and manufacturing facilities relating to chemical, biological or ballistic missiles, and nuclear weapons. That would be proportional to the threat to international peace. Any additional military action, such as removal of the existing political regime in Iraq, would seem to require a new Security Council resolution.").

${ }^{75}$ There are various accounts of the influence of "neoconservatives" in the Bush administration on the decision to invade Iraq, and how some of them advocated overthrowing the Iraqi government well before Iraq even invaded Kuwait in 1990 let alone before the imposition 
Rather, it is a wholesale abandonment of the system of norms and norm enforcement created by the Security Council in favor of an entirely new system for addressing Iraq's WMD; to wit, the creation of an entirely new Iraqi government. Seen in its best light, such an act is more in the nature of an actio popularis — or "right resident in any member of a community to take legal action in vindication of a public interest." That principle may exist in some national legal systems, but has never been recognized as a general principle of international law. ${ }^{76}$

of the WMD regime. See, e.g., Elizabeth Drew, The Neocons in Power, N.Y. REV. Books, June 12,2003 , at 20. To the extent that the true motivation of the Bush administration for invading Iraq was "regime change" regardless of WMD compliance and that the legal justification concerning Resolutions 678 and 687 was simply a pretext for accomplishing that goal, then the legal theory is all the more unpersuasive.

${ }^{76}$ Southwest African Cases (Eth. v. S. Afr.; Liber. v. S. Afr), 1966 ICJ REP. 4, 47 (July 18). 
In the end, those supporting the "revival" theory rely considerably on the first paragraph of Resolution 687, which affirmed "all thirteen resolutions noted above, except as expressly changed below to achieve the goals of the present resolution, including a formal cease-fire." ${ }^{, 77}$ Despite the stated caveat, this paragraph is cited to support the proposition that Resolution 687 preserved without change Resolution 678's general authorization to use force. Yet in the context of the language and debates surrounding Resolutions 678, 686, and 687, this indirect and caveated reference to Resolution 678 is best understood as a recognition that, as of April 3, 1991, "Member States cooperating with Kuwait" under Resolution 678 were still present in Iraq, that other states were still under an obligation to support those Member States, that those Member States remained under an obligation to report to the Security Council on their actions, and that the Security Council remained concerned that those Member States abide by their intention "to bring their military presence in Iraq to an end as soon as possible consistent with paragraph 8 of resolution 686 (1991)." ${ }^{78}$ There is nothing in the language of Resolution 687 or the associated debate suggesting that Resolution 687, paragraph one, embraced the continuation of a general authorization to use force against Iraq. ${ }^{79}$ Rather, as discussed above, the evidence points in the opposite direction.

\footnotetext{
${ }^{77}$ SC Res. 687, para. 1 (Apr. 3, 1991).

${ }^{78}$ SC Res. 687, pmbl. (Apr. 3, 1991).
}

${ }^{79}$ A shift in preambular language from Resolution 686 to Resolution 687 also casts doubt on the view that the caveated affirmation of earlier Security Council resolutions, as expressed in paragraph one of Resolution 687, was intended to preserve without change Resolution 678's general authorization to use force. The preambular language of Resolution 686 speaks of "the need to be assured of Iraq's peaceful intentions and the objective in resolution 678 (1990) of restoring international peace and security," whereas the analogous language in Resolution 687 drops the reference to Resolution 678, speaking simply of "the need to be assured of Iraq's peaceful intentions in the light of its unlawful invasion and occupation of Kuwait." Further, whereas the opening preambular paragraph of Resolution 686 both "recalled" Resolution 678 
C. Was Resolution 687 a "Cease-Fire Agreement" that Per Se Allows Force to Redress Violations?

and "reaffirmed" it, the opening preambular paragraph of Resolution 687 only "recalled" Resolution 678. 
These problems with the U.S. legal theory also undermine the general contention that whenever there is a "material breach" of a "cease-fire agreement" is violated, the parties to the conflict may once again resort to the use of force ${ }^{80}$ The theory in large part appears to rely on the general rule in the law of treaties that the material breach of a bilateral treaty by one party entitles the other party to terminate or suspend the treaty. ${ }^{81}$ Such a general contention cannot stand in the face of the problems noted above: the termination provision of Resolution 686, the creation in Resolution 687 of an alternative means of enforcing its provisions relating to WMD, and the need

${ }^{80}$ For discussion of the traditional rule, see Yoram Dinstein, The Initiation, Suspension, and Termination of War, in INTERNATIONAL LAW ACROSS THE SPECTRUM OF CONFLICT 131, 149 (Michael N. Schmitt ed., 2000) (volume 75 of the International Law Studies series of the U.S. Naval War College).

${ }^{81}$ VCLT Article 60(1) provides: "A material breach of a bilateral treaty by one of the parties entitles the other to invoke the breach as a ground for terminating the treaty or suspending its operation in whole or in part." VCLT, supra note 16, art. 60(1), 1155 U.N.T.S. 
for unilateral enforcement of Resolution 687 to be necessary and proportionate to the objectives of that resolution.

331, 346, 8 I.L.M. 679, 701. 
Moreover, even setting aside these problems, there are other flaws in the general contention that a "material breach" of a "cease-fire agreement" justifies resumption of hostilities. In the traditional practice of states, it is certainly true that a cease-fire or armistice agreement would normally only suspend hostilities, such that a serious violation of the agreement by one side could result in a recommencement of hostilities by the other side. ${ }^{82}$ In this traditional practice, there would at some point be a final agreement, often called a peace agreement, that terminates the state of war or of belligerency or the suspended hostilities, at which point the parties are divested of the right to renew military operations under any circumstances. ${ }^{83}$ This traditional practice, however, has not carried forward to contemporary state practice, especially in the United Nations era. Early in the life of the United Nations, Paul Mohn observed that "[t]erms like 'cease-fire', 'standstill', 'cessation of hostilities', 'cessation of all acts of armed force', 'discontinuance of military operations', 'truce', 'armistice' and several others are used with little discrimination and with no attempt at definition." Consequently, one cannot assign a definitive legal meaning to the term "formal cease-fire" in

${ }^{82}$ See, e.g., Convention Concerning the Laws and Customs of War on Land, Annex (Regulations), Oct. 18, 1907, art. 40, 205 Consol. T.S. 289, 295 [hereinafter "Hague Regulations"] ("Any serious violation of the armistice by one of the parties gives the other party the right of denouncing it, and even, in cases of urgency, of recommencing hostilities immediately.")

${ }^{83}$ See Richard R. Baxter, Armistices and other Forms of Suspension of Hostilities, ReCueIL Des Cours 353, 359 (1976 I); David M. Morriss, From War to Peace: A Study of Cease-Fire Agreements and the Evolving Role of the United Nations, 36 Va. J. Int'1 L. 801, 81011 (1996).

${ }^{84}$ Paul Mohn, Problems of Peace Supervision, 478 InT'L CONCILIATION 49, 51 (1952); see also 1 Sydney D. BAIley, How WARs End: The United NATIONS AND THE TERMINATION OF ARMed Conflict, 1946-1964, at 29-41 (1982); Sydney D. Bailey, Cease-Fires, Truces, and Armistices in the Practice of the U.N. Security Council, 71 AM. J. INT'L L. 461, 467-69 (1977). 
Resolution $687 .{ }^{85}$ Indeed, except for the use of that term, everything else about Resolutions 686 and 687 fits the general dichotomy between an initial agreement for a temporary cessation of hostilities and then a comprehensive final agreement setting the terms for a peace. Unlike the situation in Korea, ${ }^{86}$ there was no expectation of a further "peace agreement" that would follow Resolution 687, and certainly no expectation that either side could resume military operations at any time so long as they provided advance notification. ${ }^{87}$ Rather, Resolution 687 was the final agreement; it was a political arrangement that brought about the "definitive end to the hostilities" envisaged in Resolution $686 .^{88}$ The armies on the ground did not wait around for a further agreement after adoption of Resolution 687; as contemplated by Resolution $687,{ }^{89}$ once the UN observer mission

${ }^{85}$ See SC Res. 687, para. 1 (Apr. 3, 1991).

${ }^{86}$ The General Assembly adopted a resolution, GA Res. 498 (V) (Feb. 1, 1951), affirming the policy of the United Nations to bring about a cessation of hostilities in Korea. Agreement on an agenda for final armistice negotiations was reached on July 26, 1951. A final armistice agreement was signed two years later, on July 27, 1953. That agreement was negotiated by the United Nations Command under instructions prepared by the U.S. government. The Security Council was kept apprised of the negotiations by reports from the UN Command, but itself played no role in the political direction of the negotiations. See GOODRICH \& SiMONS, supra note 20 , at 508. Since then, no final peace agreement has been concluded.

${ }^{87}$ See Bailey, supra note 84, at 31 (stating that traditionally an "armistice was of undefined duration and the parties could resume military operations at any time so long as the enemy was warned in advance.").

${ }^{88}$ See Denis, supra note 19, at 502 ("une simple lecture de l'ensemble de la résolution 687 révèle immédiatement que cette dernière constitue bien plus qu'une simple suspension des hostilités, elle s'assimile plutôt à un véritable traité de paix dans lequel le vainqueur impose sa volonté au vancu."); Gray, After the Ceasefire, supra note 50, at 144 ("[D] espite the terminology used in Resolution 687, it is clearly more than a suspension of hostilities. The substance is that of a peace treaty."); Lavalle, supra note 48, at 56-57; Morriss, supra note 83, at 892 ("More than a 'cease-fire,' Resolution 687 sets the terms for Iraq's readmittance into the community of nations and, as such, has no equivalent under the pre-Charter regime of war rights, of which the peace treaty, the law of neutrality, and belligerent rights are a part.").

${ }^{89}$ See SC Res. 687, para. 6 (Apr. 3, 1991). 
was deployed, the combat troops went home..$^{90}$

${ }^{90}$ See Letter to Congressional Leaders on the Situation in the Persian Gulf, 1991 PuB. PAPERS 521, 522 (May 17, 1991) ("Iraq officially accepted [Resolution 687] on April 6, and a formal cease-fire has gone into effect. Accordingly, United States Armed Forced deployed in southern Iraq began withdrawing as UN peacekeeping personnel deployed into the zone, and this withdrawal was completed on May 9."); see also Wrange, supra note 19, at 497 ("the goal for the action, as declared in Resolution 678 had been satisfied, at least by and large."). 
Even if one views Resolution 687 as a "cease-fire agreement" in the traditional sense, another flaw lies in transplanting rules from the pre-Charter state era to a situation where the UN Security Council is directly involved in the cease-fire. In a situation where two contending parties have concluded a cease-fire agreement and the Security Council directs them to abide by that agreement, then the parties may not resume hostilities, even if the traditional rule would allow them to do so. As Richard Baxter put it: "This can no longer be said to be a rule of general application because the United Nations Charter and actions taken thereunder place many contemporary agreements for the suspension of hostilities beyond the reach of the parties, so that denunciation or resumption of hostilities would be unlawful." ${ }^{.91}$ Precedents sometimes pointed to in this regard are the statements of UN mediator Count Folke Bernadotte ${ }^{92}$ regarding the cease-fire imposed by the Security Council ${ }^{93}$ in 1948 concerning the conflict in Palestine and of Secretary-General Dag Hammarskjöld regarding the related 1949 armistice agreements. ${ }^{94}$ Similarly, Yoram Dinstein argues

${ }^{91}$ Baxter, supra note 83, at 382; see also Morriss, supra note 83, at 804 ("Unlike the prior regime of war rights that applied to the truce, armistice, and peace treaty before the Charter, once the Security Council acts to maintain international peace and security, the parties to the conflict are no longer free to fight, kill, and bargain for terms ending hostilities purely as an exercise of their sovereignty."); German Federal Parliament Research Service, supra note 67 , at 5 .

${ }^{92}$ See Cablegram Dated 7 August 1948 from the United Nations Mediator to the Secretary-General, UN SCOR, 3d Sess., Supp. for Aug. 1948, at 146-47, UN Doc. S/955 (1948) ("No party may take the law into its own hands and decree that it is relieved of its obligations under the resolution of the Security Council because in its opinion the other party has violated the truce. ... On these premises it is obvious that only the Security Council is competent to decide what measures should be taken against the violator of the truce and that should either party resume hostilities under any circumstances it would act against the decision of the Security Council.").

93 SC Res. 54 (July 15, 1948).

${ }^{94}$ Report of the Secretary-General to the Security Council Pursuant to the Council's 
that the 1953 armistice agreement in Korea is part of a contemporary trend in armistices which completely divest "the parties of the right to renew military operations under any circumstances whatever. An armistice of this nature puts an end to the war, and does not merely suspend the combat." 95

Resolution of 4 April 1956 on the Palestine Question, UN SCOR, 11th Sess., Supp. for Apr.June 1956, at 35, UN Doc. S/3596 (1956) (asserting that the cessation of hostilities component of a UN-blessed armistice must be viewed as independent of the other obligations in the armistice, since the former reflects an obligation on all UN member states not to use force - an obligation that cannot change by virtue of violations of other parts of the armistice).

${ }^{95}$ Dinstein, supra note 80, at 140-42. 
This placement of the cease-fire agreement "beyond the reach of the parties" is all the more apparent in a situation where the "agreement" at issue is between the United Nations and the defeated state. To the extent that the terms of Resolution 687 comprise the relevant "agreement," that agreement was offered by an international organization and then accepted by the government of Iraq. ${ }^{96}$ The terms of Resolution 687 were never captured in an agreement between Iraq and those states "cooperating" with the government of Kuwait. ${ }^{97}$ As such, when applying traditional international law theory mutatis mutandis to such a "ceasefire agreement," a violation of the

${ }^{96}$ As noted above, text accompanying notes 34 to 36, Resolution 687 stated that, once Iraq accepted the provisions of Resolution 687, "a formal cease-fire is effective between Iraq and Kuwait and the Member States cooperating with Kuwait in accordance with Resolution 678 (1990)." SC Res. 687, para. 33 (Apr. 3, 1991). Iraq then accepted the resolution. Thereafter, the president of the Security Council informed Iraq on behalf of the members of the Security Council that the conditions established in Resolution 687 "have been met and that the formal cease-fire referred to in paragraph 33 of that resolution is therefore effective." Letter Dated 11 April 1991 from the President of the Security Council to the Permanent Representative of Iraq, UN Doc. S/22485 (Apr. 11, 1991).

It is true that the "original cease-fire on the ground was in fact a decision of coalition forces", see Ruth Wedgwood, The Enforcement of Security Council Resolution 687: The Threat of Force against Iraq's Weapons of Mass Destruction, 92 AM. J. INT'L L. 724, 726 (1998), but the relevant cease-fire agreement containing conditions relating to WMD-Resolution 687-was not concluded "on the ground." See Gray, After the Ceasefire, supra note 50, at 141 ("The Security Council was not simply calling for or ordering the parties to agree on a ceasefire, as was its normal practice with regard to other conflicts. Rather, the resolution itself constitutes the ceasefire agreement.")

${ }^{97}$ Had the provisions of Resolution 687 been concluded as part of a multilateral agreement among Iraq and those states cooperating with Kuwait, even then the law of treaties would not support U.S. action simply on the basis of a material breach by Iraq. Rather, the United States would need (1) consensus among the states cooperating with Kuwait who signed the multilateral agreement (which presumably would have included states such as France) to suspend the agreement, or (2) to show that the United States was "specially affected by the breach" so as to suspend the multilateral agreement on its own, or (3) to show that the multilateral agreement is of such a character that a material breach by one party "radically changes the position of every party with respect to the further performance of its obligations under the treaty." See VCLT, art. 60(2), supra note 16, 1155 U.N.T.S. at 346, 8 I.L.M. at 701. 
agreement would only entitle the parties to the agreement to resume hostilities. In this case, the Security Council as an organ would be entitled to authorize the resumption of hostilities against Iraq, but other entities, such as member states, would not be so entitled. ${ }^{98}$ Nothing in Resolution 687 suggests that the Security Council sought to leave to member states the role of monitoring the resolution. Indeed, the opposite is the case; in paragraph thirty-four of the resolution, the Security Council decided "to remain seized of the matter and to take such further steps as may be required for the implementation of the present resolution and to secure peace and security in the area." Presumably the Security Council could authorize states to use force to implement Resolution 687, but then the analysis simply leads one back to the discussion above about whether such authorization

${ }^{98}$ See Vera Gowlland-Debbas, The Limits of Unilateral Enforcement of Community Objectives in the Framework of UN Peace Maintenance, 11 EUR. J. INT'L L. 361, 365 (“Chapter VII mechanisms provide centralized responses which create a 'vertical' relationship between implementing states and the organization, as well as regulating resort to military force."); Hofmann, supra note 19, at 21; Krisch, supra note 19, at 70-71; SAROOSHI, supra note 28, at 182 ("The better legal view is that, despite the purported delegation by the Council to Member States of the power to take military enforcement action until 'international peace and security has been restored in the region', the delegation of Chapter VII powers to Member States was terminated by conclusion of the formal ceasefire between Iraq and the UN, the terms of which were specified in resolution 687.”); Schaller, supra note 18, at 655; Wrange, supra note 19, at 504-505 ("there is no cease-fire agreement between the US-led coalition and Iraq"). 
in fact existed.

Finally, it must be noted that a Security Council resolution by its nature is not the same thing as a bilateral or even multilateral treaty: Security Council resolutions adopted under Chapter VII are decisions by an international organization that are directly binding on UN member states whether or not the state agrees with the decision. As such, it is not self-evident that rules relating to the material breach of a treaty equally apply to the material breach of a Security Council resolution. ${ }^{99}$ As it turns out, the Security Council did require Iraq to consent to the Resolution 687, but for political reasons, not out of legal necessity. In any event, obtaining Iraq's consent did not convert Resolution 687 into a bilateral or multilateral agreement whereby UN member states could decide on their own that Iraqi transgressions justified those states in using military force against Iraq. Rather, as the International Court stated in the Namibia case, it is for the Security Council to decide upon the measures to be taken in the event that a state breaches a Security Council resolution and who should take them. ${ }^{100}$

99 See Hugh Thirlway, The Law and Procedure of the International Court of Justice 1960-1989, 67 BRIT. Y.B. INT'L L. 1, 29 (1996):

It is unclear to what extent, if any, the rules as to interpretation of treaties may be applied, by extension, to the interpretation of the resolutions or decisions of international organizations. In one sense, a resolution represents, like a treaty, a meeting of wills, a coming-together of the (possibly opposing) aspirations of the States whose representatives have negotiated its drafting. In another sense, it is a unilateral act, an assertion of the will of the organ adopting it, or a statement of its collective view of a situation.

See also Wood, supra note 16, at 79 (stating that Security Council resolutions "are not legislation, nor are they judgments or 'quasi-judgments', nor are they treaties. Indeed they are for the most part very different in nature from treaties.").

${ }^{100}$ See Namibia case, supra note 16 , at 54-55. 
D. Does Security Council Practice Subsequent to Resolution 687 Support a "Revival” Theory?

The discussion above suggests that the U.S. legal theory is not well-grounded in the language of Resolutions 678 or 687 . The U.S. legal theory, however, also seeks to draw support from Security Council practice subsequent to Resolution 687, by which the Security Council itself interpreted those resolutions in a manner that supports the U.S. position. ${ }^{101}$

${ }^{101}$ Subsequent practice by states in the application of a treaty is regarded as relevant in some circumstances for purposes of interpreting the treaty, see VCLT, supra note 16, art. 31(3)(b), 1155 U.N.T.S. 331, 340, 8 I.L.M. 679, 692. This practice may include actions of states when operating as members of a UN organ (such as the Security Council), at least when those actions have a bearing upon the provisions of the UN Charter relevant to that organ. See, e.g., Competence of the General Assembly for Admission of a State to the United Nations, Advisory Opinion, 1950 ICJ REP. 4, 9 (Mar. 3) (looking to the practice of the Security Council and General Assembly when interpreting UN Charter provisions on admission of states to the United Nations); Namibia case, supra note 16, at 22 (using such practice to interpret the voting requirements of UN Charter article 27(3)); 1983 UN JURID. Y.B. 179 (UN legal counsel opinion using UN Security Council practice for the purpose of interpreting Rules 13 and 15 of the UN Security Council provisional rules of procedure).

In principle, such subsequent practice may also be probative when interpreting an ambiguous Security Council resolution (as opposed to the text of the UN Charter). See, e.g., C.F. AMERASINGHE, PRINCIPLES OF THE INSTITUTIONAL LAW OF INTERNATIONAL ORGANIZATIONS 61 (1996) ("In the interpretation of the decisions of organs which are clearly of a delegated nature . . . the principles of interpretation used are generally similar to those used in the interpretation of constitutional texts."); Dekker \& Wessel, supra note 19, at 509; Wood, supra note 16, at 91-93. Moreover, the relevant practice might include not just formal resolutions by the Security Council interpreting an earlier resolution, but rulings of its president that reflect the views of the Security Council regarding an earlier resolution.

There is some authority when interpreting the text of the constitution of an international organization, however, that the original intention of the drafters of the constitution should not be emphasized, particularly since the parties may increase or change, and because such a constitution, by its nature, should not be viewed as static. See, e.g., Certain Expenses of the United Nations (Article 17, paragraph 2, of the Charter), Advisory Opinion, 1962 ICJ REP. 151, 185 (July 20)(sep. op. of Judge Spender) [hereinafter Certain Expenses case] . To the extent that such reasoning is deemed relevant when considering the original intention of Security Council members when adopting the Security Council resolutions discussed in this analysis, it should be 
noted that the composition of the Security Council in 2003 (the year Iraq was invaded) was not the same as in 2002, nor the same in any other relevant prior year. Ten of the Security Council members in 2002, however, were members of the Security Council in 2003. 
The 1993 Attacks on Iraq. After the provisional cease-fire of February 28, 1991, the Iraqi regime was confronted with an internal breakdown of civil order, with significant resistance from Iraq Kurds in northern Iraq and Iraqi Shia in southern Iraq. ${ }^{102}$ The Iraqi government undertook severe measures to suppress the dissent, prompting massive refugee flows from northern Iraq into the mountains along the border with Turkey. In response, the Security Council adopted Resolution 688 in early April (two days after adopting Resolution 687) demanding that Iraq end its repression and insisting that Iraq allow immediate access by international humanitarian organizations. ${ }^{103}$ The resolution was adopted at a time when three states (France, the United Kingdom, and the United States) announced plans to use military aircraft to provide humanitarian supplies in northern Iraq, and, after the resolution was passed, Iraq was further warned by those states not to use armed action to prevent such relief operations. Moreover, the three states declared no-fly zones two "no-fly" zones in April 1991 for northern Iraq and in August 1992 for southern Iraq) as a means of curtailing Iraqi governments attacks against Iraqi Kurds and Iraqi Shia. In establishing the no-fly zones, the three states made somewhat vague and inconsistent statements regarding the international legal authority for such action, but to the extent that Security Council authorization was addressed, the states focused principally on Resolution 688, sometimes in conjunction with Resolution 678, but not on Resolution $687 .{ }^{104}$ The reliance on Resolution 678 arguably supports the idea of a continuing

${ }^{102}$ For more detail on this issue and the reaction of the international community, see SeAn D. Murphy, Humanitarian InTERVEntion: The United Nations in AN Evolving WORLD ORDER 166-82 (1996).

${ }^{103}$ SC Res. 688 (Apr. 5, 1991).

${ }^{104}$ See MURPHY, supra note 102, at 187-92; Mary Ellen O'Connell, Continuing Limits on 
vitality to its authorization to use force, but the legal position of the three states was never expressly endorsed by the Security Council or the UN Secretary-General, was opposed by some members of the Security Council and several other states, and certainly was opposed by Iraq. ${ }^{105}$

UN Intervention in Civil War, 67 IND. L.J. 903, (1992).

${ }^{105}$ Id. at 193; JOHNSTONE, supra note 62, at 38. 
After the adoption of Resolution 687, Iraq cooperated to a degree with the requirements of Resolution 687. However, in 1991-92 Iraq in various ways resisted those requirements, including those relating to boundary demarcation and weapons inspections. ${ }^{106}$ With respect to boundary demarcation, UNIKOM reported various incidents in which Iraq crossed into the demilitarized zone for the purpose of seizing military equipment and weapons that it had left behind. In the same time frame, Iraq progressively sought to obstruct the access of the UN special commission for weapons inspections (UNSCOM) and the weapons inspectors from the International Atomic Energy Agency ( IAEA). This obstruction led the Security Council in August 1991 to pass unanimously Resolution 707, which condemned Iraq's acts as a “material breach of the relevant provisions of resolution 687 which established a cease-fire and provided the conditions essential to the restoration of peace and security in the region." ${ }^{\prime 107}$ Nothing in the Security Council discussion of this resolution suggests any belief that it recognized or authorized the use of military force against Iraq. According to the U.S. representative, the primary purpose of this resolution was to provide new tools to UNSCOM and the IAEA, and to "send a message to Iraq" that its full compliance was expected and demanded. ${ }^{108}$ $29-30,37$.

${ }^{106}$ See Gray, After the Ceasefire, supra note 50, at 146-56; JOHNSTONE, supra note 62, at ${ }^{107}$ SC Res. 707, para. 1 (Aug. 15, 1991).
${ }^{108}$ See IRAQ AND KUWAIT, supra note 42, at 159. 
Thereafter, a series of informal statements by the President of the Security Council were issued stating that Iraq was in "material breach" of Resolution $687 .{ }^{109}$

Matters came to a head in January 1993. On January 7, Iraq informed UNSCOM and UNIKOM that Iraq would no longer allow the United Nations to transport its personnel into Iraq's territory using its own aircraft. The next day, the President of the Security Council issued a statement declaring that:

3.... Such restrictions constitute an unacceptable and material breach of the relevant provisions of resolution 687 (1991), which established the ceasefire and provided the conditions essential to the restoration of peace and security in the region, as well as other relevant resolutions and agreements.

${ }^{109}$ See id. at $416,532, \& 535$. 
4. ... The Security Council warns the Government of Iraq, as it has done in this connection in the past, of the serious consequences which would ensue from failure to comply with its obligations. ${ }^{110}$

Meanwhile, Iraq continued unauthorized incursions over the newly-drawn border with Kuwait to retrieve missiles and explosives left by Iraqi forces when retreating during the war. ${ }^{111}$ These incursions prompted a second statement by the President of the Security Council, on January 11, that Iraq was in "material breach" of its obligations under Resolution 687 and warning Iraq of "serious consequences that will flow from such continued defiance." ${ }^{112}$ To complicate matters even further,

${ }^{110}$ UN Doc. S/25081 (Jan. 8, 1993); UN SCOR, 48th Sess., 3161st mtg. at 6, 7, UN Doc. S/PV.3161 (Jan. 8, 1993).

111 See UN Doc. S/25085 (Jan. 10, 1993).

${ }^{112}$ UN Doc. S/25091 (Jan. 11, 1993); UN SCOR, 48th Sess., 3162d mtg. at 4, UN Doc. S/PV.3162 at 4 (Jan. 11, 1993). 
Iraq placed surface-to-air missiles and rearmed air defenses in the two "no-fly" zones.

On January 13, 1993, 110 French, U.K. and U.S. planes attacked four Iraqi surface-to-air missile sites and four air defense command bunkers in southern Iraq. The strike was supported by the members of the Security Council ${ }^{113}$ and by the Secretary-General who stated:

The raid yesterday, and the forces that carried out the raid, have received a mandate from the Security Council, according to Resolution 678 and the cause of the raid was the violation by Iraq of Resolution 687 concerning the cease-fire.

So, as the Secretary-General of the UN, I can say that this action was taken and conforms to the Resolutions and [sic] of the Security Council and conforms to the Charter of the United Nations. ${ }^{114}$

${ }^{113}$ Julia Preston, U.N. Members Support Allied Effort in Iraq, WASH. Post, Jan. 14, 1993, at A17.

${ }^{114}$ Statement Made by the Secretary-General of the United Nations in Paris (Jan. 14, 1993), reprinted in IRAQ AND KUWAIT, supra note 42, at 741; see also Letter to Congressional Leaders Reporting on Iraq's Compliance with United Nations Security Council Resolutions, 1992-93 PUB. PAPERS 2269 (Jan. 19, 1993) (quoting statement of UN Secretary-General 
Boutros-Ghali). 
One difficulty in assessing the meaning of this statement lies in determining which Iraqi transgression(s) were at issue: violation of the demilitarized zone; violation of the weapons inspection regime; violation of the no-fly zones; or some combination of those and perhaps even other violations. Since the attacks were on missile sites and air defense command bunkers, the action might be interpreted as relating solely to self-defense by coalition members monitoring the no-fly zones. In fact, the key coalition members justified their attacks in those terms, with only incidental reference to Iraqi defiance of UN resolutions. ${ }^{115}$ If the attacks were truly predicated on a doctrine of self-defense within the no-fly zones, then the 1993 attacks provide no relevant state practice with respect to the proper interpretation of Resolution 687 , since no state viewed the no-fly zones as authorized under Resolution 687. At the same time, to the extent that the Security Council was accepting (or tolerating) the defense of the no-fly zones, may provide support to the U.S. legal theory that Resolution 678 retained vitality even in the aftermath of Resolution 687, since the legality of the no-fly zones was predicated at least in part on Resolution 678.

The reference to Resolution 687 in the Secretary-General's statement (if accurate) suggests, however, that the Security Council had other Iraqi transgressions in mind, such as violations of the demilitarized zone and the failure to comply with the weapons inspection regime (part of Iraq's resistance to the weapons inspection regime involved threats to UN aircraft involved in transport of inspection personnel). A second attack by U.S. aircraft on January 17 was even more closely associated with the weapons-inspection regime of Resolution 687, since it targeted a nuclear

115 See Gray, After the Ceasefire, supra note 50, at 167-68 (referring to the U.K. justification); Krisch, supra note 19, at 71; JOHNSTONE, supra note 62, at 38 (referring to the U.K. and U.S. justifications). A further attack on January 18 targeted missile batteries in northern and southern Iraq. 
fabrication facility near Baghdad, ${ }^{116}$ although it must be noted that key Security Council members, such as France and Russia, questioned and distanced themselves from that attack. ${ }^{117}$

Assuming that in January 1993 the members of the Security Council were focused on Iraqi violations of Resolution 687, the Secretary-General's statement clearly reflected a position taken by the Security Council that the use of force authorization contained in Resolution 678, in some sense, remained valid in 1993 for purposes of redressing violations of Resolution 687. There are at least four ways of assessing the statement.

${ }^{116}$ See MURPHY, supra note 102, at 180; see Nora Boustany, Attack Jolts Iraqi Capital, WASH. POST, Jan. 18, 1993, at A1.

${ }^{117}$ See Denis, supra note 19, at 487; Krisch, supra note 19, at 72. 
First, one might regard the position taken act by the Security Council as ultra vires ${ }^{118}$ on grounds that - if the proper interpretation of Resolutions 678,686 , and 687 as set forth in the prior sections is correct- there was no prior authorization for states to use force against Iraq which the Security Council could recognize in 1993 as being a "mandate". There was no means for Iraq or any other state to challenge the step taken by the Security Council so as to prevent the operation of the "mandate", but that alone does not mean the Security Council's action was lawful. If this

${ }^{118}$ See generally Terry Gill, Legal and Some Political Limitations on the Power of the UN Security Council to Exercise its Enforcement Powers Under Chapter VII of the Charter, 26 NETH. Y.B. INT'L L. 33 (1995); Ebere Osieke, The Legal Validity of Ultra Vires Decisions of International Organizations, 77 AM. J. INT'L L. 239 (1983). By way of example, in the IMCO case, the International Court found that the IMCO Assembly, when electing its Maritime Safety Committee, misinterpreted a term in its Charter, and thus acted ultra vires. See IMCO case, supra note 22, at 150 . Thereafter, the elected Committee was dissolved and a new committee elected. See Elihu Lauterpacht, The Legal Effect of Illegal Acts of International Organizations, in CAMBridge EsSAYs In InTERNATIONAL LAw 88, 99-106 (Oceana Pub. 1965). 
interpretation is correct, then the statement by the Secretary-General provides no precedent for any subsequent use of force against Iraq.

Second, one might regard the statement, which speaks as though a "mandate" is being issued in 1993, as constituting a new authorization for states to use military force against Iraq. Here, too, the act is vulnerable to an ultra vires challenge. While the Security Council could authorize such force by adopting a new resolution in accordance with Chapter VII, arguably it could not do so informally simply through closed door consultations that are then communicated publicly by the Secretary-General. ${ }^{119}$ As the International Court has stated, "[t]he political character of an organ cannot release it from the observance of treaty provisions established by the Charter, when they constitute limitations on its powers or criteria for its judgment." ${ }^{, 120}$ In other words, the failure to

${ }^{119}$ Most important decisions of the Security Council are developed via confidential consultations, but they are then formalized in public meetings, where speeches and votes are officially recorded. See James S. Sutterlin, The Past as Prologue, in The OnCE AND FuturE SECURITY COUNCIL, 1, 8-9 (Bruce Russett ed., 1997).

${ }^{120}$ Conditions of Admission of a State to the United Nations (Charter, Art. 4), Advisory Opinion, 1948 ICJ REP. 57, 64 (May 28). 
convene a formal meeting leading to a resolution adopted under Chapter VII is a procedural irregularity that resulted in an ultra vires act by the Security Council, such that the consequences of that act have no legal meaning. ${ }^{121}$

${ }^{121}$ For cases addressing whether procedural irregularities can lead to an ultra vires act of an international organization, see Appeal Relating to the Jurisdiction of the ICAO Council (India v. Pak.), 1972 ICJ REP. 46 (Aug. 18); Admissibility of Hearings of Petitioners by the Committee on South West Africa, Advisory Opinion, 1956 ICJ REP. 23 (June 1); Voting Procedure on Questions Relating to Reports and Petitions Concerning the Territory of South West Africa, Advisory Opinion, 1955 ICJ REP. (June 7). 
UN practice in the field of peace and security, of course, is replete with instances of organs acting in a manner not envisaged by the UN Charter-ranging from the practice of permanent members abstaining (rather than concurring) on substantive issues decided by the Security Council; ${ }^{122}$ to the reading of UN Charter article twenty-three's reference to "USSR" as meaning now the Russian Federation; ${ }^{123}$ to the practice of deploying peacekeeping forces; ${ }^{124}$ to the use of the Uniting for Peace resolution ${ }^{125}$; to the expansion of the concept of "threat to the peace" from transborder uses of force to internal matters, such as human rights concerns; ${ }^{126}$ to the undertaking of enforcement measures under Chapter VII through delegation to national forces, rather than through forces provided to the United Nations pursuant to agreements under UN Charter Article 43. ${ }^{127}$ Among other things, the Certain Expenses ${ }^{128}$ and Namibia ${ }^{129}$ advisory opinions stand for the proposition that the powers of the Security Council are not narrowly limited to a strict construction

${ }^{122}$ See 1 The Charter of The United NATIONS, supra note 73, at 493-98.

${ }^{123}$ See id. at 439 .

124 See id. at 684-86.

${ }^{125}$ GA Res. 377 (V) (Nov. 3, 1950).

${ }^{126}$ See 1 The ChARTER OF THE United NATIONS, supra note 73, at 720-21, 723-25.

${ }^{127}$ See id. at 756-58. For a general discussion of these types of developments, see Frederic L. Kirgis, Jr., The Security Council's First Fifty Years, 89 AM. J. InT’L L. 506 (1995). The ability of UN organs to adapt and develop the meaning of the Charter has prompted Thomas Franck to characterize the Charter as a "living tree." See FrANCK, supra note 35, at 26 n. 19.

${ }^{128}$ Certain Expenses case, supra note 101, at 167.

${ }^{129}$ Namibia case, supra note 16, at 52 (stating that "the powers of the Council under Article 24 are not restricted to the specific grants of authority contained in Chapters VI, VII, VIII and XII .... The only limitations are the fundamental principles and purposes found in Chapter I of the Charter."). 
of the UN Charter. Rather, the Council can act on a liberal construction of its authority derived from its general powers to maintain and restore international peace and security. ${ }^{130}$

${ }^{130}$ See Kirgis, supra note 127, at 519-20 (recounting use of presidential statements as a means of reflecting consensus reached in closed Council sessions). Such practice is often supported by relying either on a doctrine of "implied powers" or on a "principle of effectiveness" in advancing the object and purpose of the organization when interpreting the language of its constituent instrument. See 1 THE CHARTER OF THE UNITED NATIONS, supra note 73, at 30-31; Krysztof Skubiszewski, Implied Powers of International Organizations, in

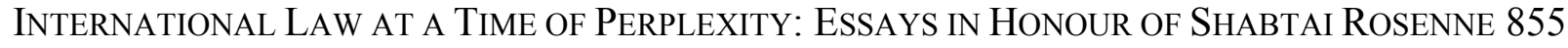
(Yoram Dinstein \& Mala Tabory eds., 1989); Gerald FitzMAurice, The LAW AND Procedure OF THE INTERNATIONAL COURT OF Justice 345 (1986); Andrea Giardina, The Rule of Law and Implied Powers in the European Communities, 1 ITAL. Y.B. INT'L L. 99 (1975); Effect of Awards of Compensation Made by the United Nations Administrative Tribunal, Advisory 
Opinion, 1954 ICJ REP. 57 (July 13) (finding an implied UN power to establish an administrative tribunal to settle disputes between the United Nations and its staff); Reparation for Injuries Suffered in the Service of the United Nations, 1949 ICJ REP. 174, 213 (Apr. 11) (stating that "[u]nder international law, the Organization must be deemed to have those powers which, though not expressly provided in the Charter, are conferred upon it by necessary implication as being essential to the performance of its duties."); Conference of the International Labour Organization to Regulate, Incidentally, the Personal Work of the Employer, Advisory Opinion, 1926 PCIJ REP. SER. B, NO. 13 at 18 (July 23) (finding an ILO implied power to regulate the work of employers); 1962 UN JURID. Y.B. 238 (UN legal counsel opinion using the "principle of effectiveness" in interpreting a Security Council resolution regarding import of arms and war materials into the Congo); Tadi_Decision, supra note 16, at para. 71, 105 INT'L L. REP. 419, at 489-90 (finding that, when interpreting the jurisdictional provisions of the ICTY statute adopted by the Security Council, a literal interpretation did not lead to a clear result, such that "the Appeals Chamber will therefore consider the object and purpose behind the enactment of the Statute."). 
Nevertheless, authorizing the use of force against a UN member state without undertaking the procedures for voting envisaged in the UN Charter (and in the Security Council's provisional rules of procedure) is much further outside the scope of permissible behavior under the Charter than existed in, for example, the Certain Expenses case. Charter provisions and rules of procedure can be interpreted creatively to advance fundamental objectives of the United Nations, but law and procedure cannot simply be disregarded and still retain the name of "law". In any event, if this statement was a new authorization to use force against Iraq, then the statement still provides no precedent for any subsequent use of force against Iraq, since there would need to be further "mandates" issued at future times for future "raids" and "the forces that carried them out."

Third, one might regard the Secretary-General's statement as an authoritative interpretation of Resolutions 678 and 687 (and implicitly 686) by the Security Council. While the arguments previously offered regarding the language and history of Resolutions 678, 686, and 687 may be persuasive, they are by no means definitive, and if the organ issuing the resolutions develops an alternative interpretation, that interpretation cannot simply be discounted as wrong. Just as the drafters of the UN Charter envisaged each organ interpreting "such parts of the Charter as are applicable to its particular functions, ${ }^{, 131}$ so too may the Security Council interpret the meaning of its prior resolutions. If this interpretation is correct, then the Secretary-General's statement might

${ }^{131}$ Report of Special Subcommittee of Committee IV/2 on the Interpretation of the Charter, Doc. 750, IV/2/B/1, 13 U.N.C.I.O. Docs. at 831-32 (1945); see Certain Expenses case, supra note 101, at 168 (finding that "each organ must, in the first place at least, determine its own jurisdiction"); Delimitation of the Polish-Czechoslovakian Frontier (Question of Jaworzina), Advisory Opinion, 1923 PCIJ (Ser. B) No. 8, at 37 (Dec. 6) (asserting an international legal principle of eius est interpretare legem cuius condere, meaning he who has the legal power to take a decision also has the power to interpret the decision); Wood, supra note 16 , at 82 ("Only the Security Council, or some body authorized to do so by the Council, may give an authentic interpretation in the true sense."). 
serve as a precedent for subsequent uses of force against Iraq for violations of Resolution 687, along the lines of the theory expressed by the United States in 2003. However, this interpretation of the statement would also be consistent with a view that revival of Resolution 678 must coincide with at least an informal decision by the Security Council that Resolution 687 has been breached and further that the time had come for a use of military force to redress that breach.

Finally, following the insights of legal realism, one might regard the Security Council as having developed an "operational code" separate from the language of the Charter and the Council's rules of procedure. If members of the Security Council were not willing politically to adopt a new resolution in 1993 authorizing the use of force, but were prepared to tolerate (or at least not resist) the use of force by certain member states, then they signaled as much among themselves, and publicly made a statement designed to paper over a lack of formal authority. To establish such an operational code, however, it would be desirable to see the same type of incident repeated over time as part of a systematic practice, which has not been the case with respect to recognizing "mandates" to use force. ${ }^{132}$ Moreover, the facts at issue in January 1993 can easily be read as supporting a relatively narrow scope for such an operational code. The facts pertained not to a broad, large-scale use of force but, rather, to a use of force principally associated with protecting aircraft monitoring the no-fly zones, ostensibly for humanitarian purposes. There is no compelling reason to believe that a narrow operational code of this type should be read to support a wholesale invasion of Iraq.

${ }^{132}$ Most cases involving subsequent practice as a means of interpreting a norm rely on repeated occurrences. See, e.g., Namibia case, supra note 16, at 22; AMERASINGHE, supra note 101 , at 50 ("It would seem that in general, where practice constitutes an interpretation, it must be repeated and consistent."); but see Jurisdiction of the European Commission on the Danube Between Galatz and Braila, Advisory Opinion, 1927 PCIJ REP. SER. B, No. 14, at 57-58 (Dec. 8) (relying upon only one occurrence of the subsequent practice). 
Finally, an operational code divined from the January 1993 attacks presumably entails at least an informal decision by the Security Council that Resolution 687 has been breached and that a use of military force is necessary to redress that breach.

The 1998 Attacks on Iraq. From 1993 until 1998, UNSCOM and the IAEA enjoyed mixed success. Although various WMD was destroyed, ${ }^{133}$ Iraq repeatedly denied or delayed access to some facilities by the inspection teams, leading to the belief within UNSCOM, and by many states, that Iraq was playing a game of "hide and seek" to cover-up prohibited biological and chemical weapons capability. ${ }^{134}$ In March 1998, the Security Council unanimously adopted Resolution 1154, which adopted a new UN-Iraq memorandum of understanding on the conduct of weapons inspections and warned Iraq that continued violations of its WMD obligations "would have severest consequences". ${ }^{135}$ When adopting this resolution, a majority of the Security Council members stated

${ }^{133}$ UNSCOM successfully supervised the destruction of forty-eight operational longrange missiles, fourteen conventional missile warheads, six operational mobile launchers, twenty-eight operational fixed launch pads, thirty-two fixed launch pads under construction, thirty missile chemical warheads, 38,500 filled and empty chemical munitions, 690 tons of chemical weapons agents, more than 3,000 tons of precursor chemicals, 426 pieces of chemical weapons production equipment, and ninety-one pieces of related analytical equipment, an entire biological weapons facility (at Al-Hakam), and a variety of biological weapons production equipment and materials. See Note by the Secretary-General, UN Doc. S/1998/920 (1998); see also The United NATIONS AND THE IRAQ-KuWAit Conflict 1990-1996, UN Doc. DPI/1770, UN Sales No. E.96.I.3 (1996).

${ }^{134}$ See What the Inspectors Can't Find and Why They Can't Find It, N.Y. TIMES, Dec. 20, 1998, at WK5 (table compiled by a nongovernmental research group that tracks the spread of weapons of mass destruction). For an account of UNSCOM's difficulties, largely based on interviews with an UNSCOM Chief Inspector, of U.S. nationality, who resigned in protest in August 1998, see Barton Gellman, A Futile Game of Hide and Seek, WASH. Post, Oct. 11, 1998, at A1; Barton Gellman, Arms Inspectors "Shake the Tree," WASH. Post, Oct. 12, 1998, at A1; see also Scott Ritter, Endgame: Solving the IraQ Problem Once AND FOR All (1999).

135 SC Res. 1154 (Mar. 2, 1998). Language stating the Iraq's continued violations "would have the severest consequences" was altered by dropping the word "the" apparently in a further 
that additional Security Council authorization would be needed before force could be used to implement the weapons inspections, ${ }^{136}$ and the resolution contained no language authorizing states to undertake "all necessary measures" or "all necessary means" to enforce the resolution. Moreover, the resolution stated that the Security Council would "remain actively seized of the matter, in order

effort to signal that the use of force was not authorized. See Dekker \& Wessel, supra note 19, at 509.

${ }^{136}$ See UN Doc. S/PV.3858, passim (1998). Three permanent members-China, France, and Russia - all declared that the resolution did not authorize the use of military force. Id. at 1415, 17; see also Dekker \& Wessel, supra note 19, at 509 (stating that "[i]t was clear that the term 'severest consequences' was not to be seen as a synonym for 'all necessary means'."). 
to ensure implementation of this resolution," 137 thus implying that implementation was not a matter for individual states to decide on their own. ${ }^{138}$

${ }^{137}$ SC Res. 1154, para. 5.

${ }^{138}$ See Denis, supra note 19, at 512; Frowein, supra note 25, at 110-11. 
On October 31, 1998, Iraq formally halted all cooperation with UNSCOM. ${ }^{139}$ In response, the United States embarked on an intense diplomatic initiative with allies in the Middle East and Europe to promote support for all possible options, including the use of force, to obtain Iraqi compliance. ${ }^{140}$ On November 5, the Security Council adopted Resolution 1205 condemning Iraq's decision as "a flagrant violation of Resolution 687" and demanded that Iraq immediately and unconditionally resume cooperation with UNSCOM (the resolution did not address the issue of use of force by other states against Iraq). ${ }^{141}$ Apparently, some members of the Security Council insisted upon the term "flagrant violation" instead of "material breach" out of a belief that certain other members (such as the United Kingdom and United States) viewed the latter term as constituting an authorization to use force. ${ }^{142}$ Despite the switch in terminology, at the meeting of the Security Council, the U.K. representative warned that legal authorization for states to use force against Iraq might be revived if there were a serious breach by Iraq of its obligations under Resolution 687; the

${ }^{139}$ See Letter Dated 31 October 1998 from the Deputy Executive Chairman of the Special Commission Addressed to the President of the Security Council, UN Doc. S/1998/1023 (Oct. 31, 1998); Letter Dated 2 November 1998 from the Executive Chairman of the Special Commission Addressed to the President of the Security Council, UN Doc. S/1998/1032 (Nov. 4, 1998); Barbara Crossette, In New Challenge to the U.N., Iraq Halts Arms Monitoring, N.Y. TimES, Nov. 1, 1998, at A1; John M. Goshko \& Howard Schneider, Iraq Halts All Work by U.N. Inspectors, WAsh. Post, Nov. 1, 1998, at A1.

${ }^{140}$ Bradley Graham, Cohen Seeks Cooperation from Saudis, WASH. Post, Nov. 4, 1998, at A21; Steven Lee Myers, U.S. Moves Ahead with Preparations for Strikes on Iraq but Sets No Deadline, N.Y. TIMES, Nov. 6, 1998, at A8; Steven Lee Myers, U.S. Works to Win Allies' Support for Using Force Against Iraq, N.Y. TIMES, Nov. 5, 1998, at A15; Howard Schneider, Cohen Bids for Allies in New Iraqi Impasse, WAsh. Post, Nov. 5, 1998, at A56.

${ }^{141}$ SC Res. 1205, paras. 1 \& 2 (Nov. 5, 1998); see Barbara Crossette, U.N., Avoiding Talk of Force, Criticizes Iraq on Arms Team, N.Y. Times, Nov. 6, 1998, at A1.

${ }^{142}$ See Lobel \& Ratner, supra note 25, at 154; Wrange, supra note 19, at 503. 
U.S. representative simply stated that the United States had sufficient authority to use force. ${ }^{143}$

After some back and forth between Iraq and UNSCOM, UNSCOM reported to the Security Council on December 15 that the commission "is not able to conduct the substantive disarmament work mandated to it by the Security Council."144 The next day, the United States and the United Kingdom commenced "Operation Desert Fox", a seventy-hour missile and aircraft bombing campaign against approximately a hundred sites in Iraq: military command centers, intelligence and communications facilities, missile factories, airfields, an oil refinery allegedly used to evade UN economic sanctions, and the headquarters and bases of the Iraqi Republican Guard. ${ }^{145}$

${ }^{143}$ UN Doc. S/PV.3939 at 10, 11 (Nov. 5, 1998).

${ }^{144}$ Letter Dated 15 December 1998 from the Secretary-General Addressed to the President of the Security Council, UN Doc. S/1998/1172 (Dec. 15, 1998) (transmitting UNSCOM and IAEA reports); see Barton Gellman, Iraq Hasn't Cooperated, Arms Inspector General Reports, WASH. PosT, Dec. 16, 1998, at A1. For Iraq's views, see Letter Dated 15 December 1998 from the Secretary-General Addressed to the President of the Security Council, UN Doc. S/1998/1173 (Dec. 15, 1998) (transmitting letter from Iraq).

${ }^{145}$ See Francis X. Clines \& Steven Lee Myers, Impeachment in the House Delayed as Clinton Launches Iraq Air Strike, Citing Military Need to Move Swiftly, N.Y. TIMES, Dec. 17, 
1998, at A1; Steven Lee Myers, U.S. and Britain End Raids on Iraq, Calling Mission a Success, N.Y. TIMES, Dec. 20, 1998, at 1; see generally Sean M. Condron, Justification for Unilateral Action in Response to the Iraqi Threat: A Critical Analysis of Operation Desert Fox, 161 MIL. L. REV. 115 (1999). 
This time there was no public statement by either the Secretary-General or the President of the Security Council indicating a mandate for the attacks, let alone a Security Council resolution to that effect. Indeed, China and Russia sharply criticized the action as an unprovoked use of force that violated principles of international law and the UN Charter. ${ }^{146}$ Other, non-permanent members also criticized the attacks as unlawful. ${ }^{147}$ At no point did the Security Council adopt a resolution prohibiting the use of force against Iraq, but there is little doubt that such a resolution would have been vetoed by both the United Kingdom and the United States.

Those states supporting the legality of the attack made reference to Resolutions 1154 and 1205 , and advanced the "revival" theory of Resolutions $678 / 687$ as justifying states to attack on their own initiative. ${ }^{148}$ For those states, the inability to obtain the Security Council's political blessing was unfortunate, but did not undermine the existing legal authority. Some supporters even argued that notwithstanding the various statements made by members in Security Council meetings, there actually was tacit authorization for the use of force when it was undertaken. ${ }^{149}$ The principal deputy legal adviser of the U.S. Department of State asserted in 1998 that:

146 See UN Doc. S/PV.3955 at 4-5 (Dec. 16, 1998); see also William Drozdiak, Nations Find Fault with Airstrikes, WASH. Post, Dec. 17, 1998, at A29; Steven Erlanger, U.S. Decision to Act Fast, and Then Search for Support, Angers Some Allies, N.Y. TIMES, Dec. 17, 1998, at A14. France was negative, but more equivocal, stating that it "deplores the chain of events that led to the American military strikes against Iraq and the serious human consequences that they may have for the Iraqi population." UN Doc. S/PV.3955, id., at 12; but see Krisch, supra note 19, at 68 (recounting testimony by the French Foreign Minister that the attacks might be based on Resolution 1154).

147 See UN Doc. S/PV.3955, supra note 146, at 10 (Sweden \& Brazil), \& 12 (Kenya).

148 See id., at 5-7 (United Kingdom), \& 8-10 (United States); see also Krisch, supra note 19 , at 66-67.

${ }^{149}$ See, e.g., Wedgwood, The Enforcement of Security Council Resolution 687, supra 
note 96 , at $727-28$. 
[I]n a series of decisions, either by the Council or the President acting on behalf of the Council, the Council stated that particular violations by Iraq of these obligations were material breaches of the cease-fire. On those occasions, the Council clearly understood that the consequence, if Iraq did not back down, would be the use of force by the United States and others cooperating with it. ${ }^{150}$

Yet the refusal to accept any language implying an authorization to use force when adopting Resolutions 1154 and 1205 (including the purportedly significant words of "material breach"), the lack of any informal Security Council "blessing" to this use of force against Iraq at the time it was taken (notwithstanding U.S. efforts to obtain such support), and the post-attack criticism by several members of the Security Council, point in a different direction. Without Security Council support, one is left with either a faulty interpretation of Resolutions 678, 686, and 687-one that cannot be corrected by a statement by the Secretary-General in 1993 — or with a theory that Resolution 678 remained viable but only when the use of force is specifically endorsed by the Security Council, formally or informally. Since no such endorsement occurred, the action could not be justified on the basis of a revival of Resolution 678. As for the notion of tacit authorization from the Security Council,

the difficulty of divining and attributing motivations to state actors and of interpreting unrecorded or informal Security Council discussions suggests that a world order that permits

${ }^{150}$ See Michael J. Matheson, Panel on Legal Authority for the Possible Use of Force Against Iraq, Proceedings of the 92ND AnNUAL MeEting OF THE ASIL 136, 141 (1998). 
implied Council authorizations to use force would depend not on clearly held expectations of states but, rather, on the nuanced interpretation of ambiguous state actions. That seems to be a dubious way to implement a basic international norm. ${ }^{151}$

${ }^{151}$ Lobel \& Ratner, supra note 25, at 133-34; see Hofmann, supra note 19, at 20-21 (arguing that to allow states to scavenge UN resolutions for ambiguity on a matter so fundamental as war and peace undermines the principle of "Rechtssicherheit", or legal certainty and foreseeability, especially since an authorization to use force itself threatens international peace and security); see generally Olivier Corten \& François Dubuisson, L'Hypothèse d'une Règle Émergente Fondant une Intervention Militaire sur une "Autorisation Implicite" du Conseil de Sécurité, 104 Revue GÉNÉRALE DE Droit InTERnATIONAL Public 873 (2000) (surveying state practice and concluding that uses of force other than self-defense must be based on a clear authorization from the Security Council). 
Other Attacks on Iraq Relating to the No-fly Zones. The legal interpretation of Security Council practice with respect to the use of force against Iraq remained problematic in the 1990's to early 2000's because of repeated uses of force against Iraq by the United States and United Kingdom (and initially France) relating to the no-fly zones. These attacks often were responses to Iraqi attacks or threats upon coalition aircraft patrolling in the zones, ${ }^{152}$ and at times occurred at a frequency of up to five to ten days every month. ${ }^{153}$ Professor Dinstein has pointed to these military actions as evidence that Iraqi violations of the cease-fire terms contained in Resolution 687 could trigger a lawful use of force by the coalition in response. ${ }^{154}$ However, the states conducting these attacks did not base their actions on alleged violations of Resolution 687; rather, the attacks were based on the asserted right to self-defense in maintaining the two no-fly zones, which in turn were based on authority derived from either (1) Resolution 678 in combination with Resolution 688 or (2) the doctrine of humanitarian intervention. ${ }^{155}$ Indeed, the unwillingness to read Resolution 687 so broadly as to justify the creation and defense of the no-fly zones as a means of protecting Iraqi

${ }^{152}$ See, e.g., Barton Gellman, U.S. Planes Hit Iraqi Site After Missile Attack, WASH. Post, Dec. 29, 1998, at A1; Steven Lee Myers, F-16's Attack Iraqis After Missiles Are Fired at Allied Jets, N.Y. TIMES, Dec. 31, 1998, at A3; Bradley Graham, Strikes Hit Civilians, Iraq Says, Wash. Post, Jan. 26, 1999, at A1; Steven Lee Myers, U.S. Presses Air Attacks on Iraq In a Low-Level War of Attrition, N.Y. TIMES, Feb. 3, 1999, at A1; Thomas E. Ricks, Jets Hit Targets Near Baghdad in Biggest Airstrike in 2 Years, WASH. Post, Feb. 17, 2001, at A1; Jane Perlez, Allies Bomb Iraqi Air Defenses In Biggest Attack in 6 Months, N.Y. TIMES, Aug. 11, 2001, at A6.

${ }^{153}$ See Latest Bombings Are Part of a Long Campaign, N.Y. TimEs, Feb. 17, 2001, at A4.

${ }^{154}$ Dinstein, supra note 80, at 149.

${ }^{155}$ See supra note 112; Christine Gray, From Unity to Polarization: International Law and the Use of Force against Iraq, 13 EUR. J. INT'L L. 1, 9-11, 16-18 (2002); Christopher Greenwood, International Law and the NATO Intervention in Kosovo, 49 I.C.L.Q. 926 (2000) (discussing the protection of Iraqi Kurds and Shiites as precedents for a doctrine of humanitarian 
Kurds and Shiites military actions reflects a level of fidelity even by the intervening states to the subject matter of Resolution $687 .{ }^{156}$ It is correct that the intervening states in part relied on a

intervention).

${ }^{156}$ It should also be noted that, in June 1993, the United States attacked targets in Iraq in response to a plot to assassinate former President George H.W. Bush during a visit to Kuwait in April 1993. The United States justified its attack on the basis of self-defense and not on any mandate from Security Council resolutions. The reaction of the members of the Security Council, for the most part, was sympathetic. For analyses, see Dino Kritsiotis, The Legality of the 1993 US Missile Strike on Iraq and the Right of Self-Defence in International Law, 45 ICLQ 
continuing vitality of Resolution 678 to support the no-fly zones, but that interpretation was never adopted by the Security Council, formally or informally, was rejected by several states and by the Secretary-General, and has not been generally endorsed in scholarly commentary. ${ }^{157}$

162 (1996); Forum: The Baghdad Bombing: Self-defence or Reprisals?, 5 EUR. J. INT’L L. 120 (1994).

157 See Murphy, Force and Arms, supra note 25, at 290-91; Gray, From Unity to Polarization, supra note 155, at 16-18 (noting that China, Russia, and ultimately even France rejected the legality of such attacks). 
The 2003 Attack on Iraq. The attacks in 1998 did not result in Iraq readmitting the UNSCOM and IAEA inspectors. A belief by several members of the Security Council that UNSCOM needed to be reconstituted so as to reflect a more balanced body led to the adoptionafter a year of discussions - of Resolution $1284 .^{158}$ That resolution established a new inspection agency, the UN Monitoring, Verification and Inspection Commission (UNMOVIC), to verify Iraq's compliance with Resolution 687. UNMOVIC proceeded to establish its structure, recruit and train personnel, and draft a work plan, but Iraq remained unwilling to allow the inspectors to return absent an immediate lifting of the UN sanctions on Iraq.

${ }^{158}$ SC Res. 1284 (Dec. 17, 1999). China, France, Malaysia, and Russia all abstained. 
The events leading up to the invasion of Iraq in March 2003 reveal Security Council practice relevant to the U.S. legal theory. ${ }^{159}$ In late 2002, the United States aggressively pursued support from foreign states and at the United Nations for armed intervention in Iraq. ${ }^{160}$ Iraq signaled a willingness to allow inspectors to return, clearly as a means of forestalling further UN action, but it was generally accepted that further pressure was needed on Iraq to achieve compliance. In the course of weeks of intense negotiations with the other Security Council members, the United Kingdom and the United States informally circulated to other Security Council members a draft resolution that would require Iraq to disclose its WMD capabilities and to allow intrusive weapons inspections. Moreover, the draft resolution would provide that "failure by Iraq to comply and cooperate fully in accordance with the provisions laid out in this resolution, shall constitute a further material breach of Iraq's obligations, and that such breach authorizes member states to use all necessary means to restore international peace and security in the area." ${ }^{, 161}$ Other Security Council members, especially France, stated that they would not accept a resolution that automatically triggered the use of force against Iraq. ${ }^{162}$ Consequently, the United States agreed to drop the

${ }^{159}$ For a general discussion of those events, see Sean D. Murphy, Contemporary Practice of the United States Relating to International Law, 96 AM. J. INT’L L. 956 (2002); id., 97 AM. J. INT'L L. 419 (2003).

${ }^{160}$ See, e.g., Address to the United Nations General Assembly in New York City, 38 WeEkly COMP. Pres. Doc. 1529, 1529-32 (Sept. 16, 2002) (speech by President Bush asserting that "[w]e will work with the U.N. Security Council for the necessary resolutions."); Julia Preston \& Todd S. Purdum, U.S. Moves to Persuade Security Council to Confront Iraq on Arms Inspections, N.Y. TIMES, Sept. 14, 2002, at A6.

${ }^{161}$ See Latest U.S.-Britain Draft of Resolution in the U.N., N.Y. TIMES, Oct. 2, 2002, at A12.

${ }^{162}$ See, e.g., Julia Preston \& Eric Schmitt, U.S.-French Split on Iraq Deepens, N.Y. TIMES, Oct. 15, 2002, at A1. 
provision authorizing the use of force ${ }^{163}$ and distributed a revised draft resolution that called for intrusive weapons inspections and warned that Iraq may face "severe consequences" if it failed to disarm. ${ }^{164}$ The revised draft did not expressly authorize military force in the event that Iraq failed to comply, but other Security Council members nevertheless resisted the draft on grounds that it implicitly authorized the use of force by a member state (such as the United States) who on its own determined that Iraq was in non-compliance. Instead, other Security Council members (particularly France and Russia) wished to see — at whatever point Iraq was considered to be in non-compliance with the first resolution - the Security Council debate and adopt a second resolution authorizing the use of force ${ }^{165}$ Ultimately, the United States agreed that the new resolution could envisage a Security Council debate on whether Iraq was in non-compliance before any military action would take place, but the United States argued that the resolution should leave open the possibility of military action without a second Security Council resolution, otherwise the first resolution would

${ }^{163}$ See Karen DeYoung \& Colum Lynch, U.S. Proposal May Break Impasse at U.N. Over Iraq, WASH. Post, Oct. 18, 2002, at A32.

${ }^{164}$ See Colum Lynch, U.S. Offers Concessions in U.N. Draft on Iraq, WASH. Post, Oct. 22, 2002, at A22.

165 See Colum Lynch, France and Russia Raise New Objections to Iraq Plan, WASH. Post, Oct. 23, 2002, at A23; see also UN Doc. S/PV.4625 at 13 (Resumption 3) (Oct. 17, 2002) (France) (proposing a "two-stage" approach whereby first the Security Council would adopt a "rules of the game" resolution and second, if Iraq failed to comply, would meet to decide on appropriate measures to take); id. at 5 (Mexico) (supporting the two-stage approach); id. at 20 (Ireland) (asserting that if Iraq does not comply with a first resolution, the Council would then decide on whether to enforce compliance); $i d$. at 27 (Mauritius) (stating that "much as it is important for Iraq to comply with Security Council resolutions and to cooperate with weapons inspectors, it is equally important that in the even of any non-compliance, the Security Council retain its centrality and authority in deciding the most important course of action to obtain compliance."). 
not be effective. ${ }^{166}$

${ }^{166}$ See Karen DeYoung \& Colum Lynch, 6 Words Separate U.S., France on Iraq Language, WASH. Post, Oct. 31, 2002, at A19; Julia Preston, Shift Toward the U.S. Stand on Iraq is Noted in Council, N.Y. TIMES, Nov. 1, 2002, at A14 (quoting the U.S. deputy representative to the United Nations that the resolution "is an attempt to send a clear message to Iraq and to get a good inspection regime under way"). 
On November 8, the Security Council unanimously adopted Resolution $1441,{ }^{167}$ which recalled Resolutions 678 and 687 and decided (1) that Iraq "has been and remains in material breach of" Resolution 687 (1991); ${ }^{168}$ (2) to afford Iraq "a final opportunity to comply with its disarmament obligations"; ${ }^{169}$ (3) to set up an enhanced inspection regime to bring Iraq in compliance; ${ }^{170}$ (4) that Iraq shall provide UNMOVIC, the IAEA, and the Security Council within 30 days "a currently accurate, full, and complete declaration of all aspects of its" WMD programs; ${ }^{171}$ (5) that false statements or omissions in the declaration would constitute a further material breach; ${ }^{172}$ (6) that Iraq shall provide UNMOVIC and the IAEA “immediate, unimpeded, unconditional, and unrestricted access", ${ }^{173}$ (7) that, pursuant to paragraphs four and eleven of the resolution, UNMOVIC and the IAEA should report to the Council any false statements or omissions in Iraq's declaration or any interference by Iraq with inspection activities, ${ }^{174}$ and (8) upon receipt of such a report, pursuant to paragraph twelve of the resolution, to convene immediately "in order to consider the situation and the need for full compliance with all of the relevant Council resolutions in order to secure

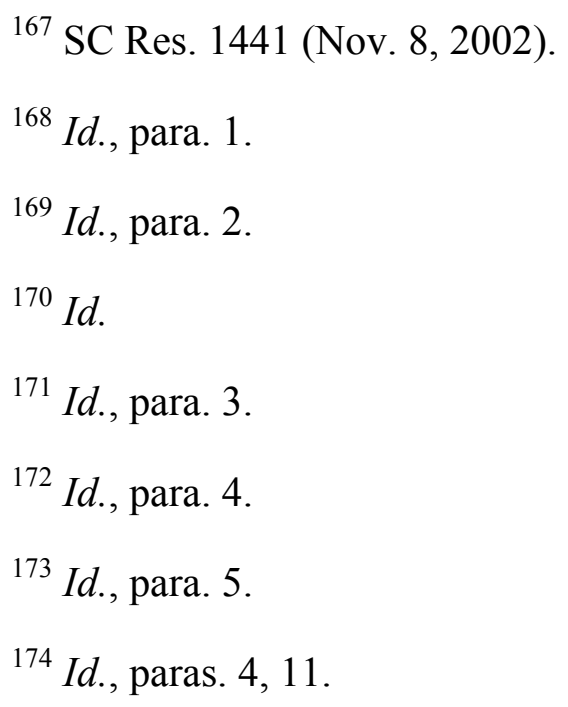


international peace and security" ${ }^{175}$ Finally, the Security Council recalled "that the Council has repeatedly warned Iraq that it will face serious consequences as a result of its continued violations of its obligations" and decided "to remain seized of the matter."

\footnotetext{
${ }^{175}$ Id., para. 12.

${ }^{176}$ Id., paras. $13-14$.
} 
In support of the U.S. legal theory, Resolution 1441 did use the language of "material breach" that had been eschewed in November 1998 when the Security Council adopted Resolution 1205. Yet, while the language of the resolution was not a model of clarity, ${ }^{177}$ there was certainly no express authorization in the resolution for the use of force and the threatening language of the resolution is best understood as a serious effort to convince Iraq to comply, not as an implicit authorization for the use of force. Indeed, the debate at the Security Council reflects a belief by all the members (with the exception of the United States) that they had, after intensive weeks of negotiation, reached consensus on a "two-stage process" whereby, if Iraq failed to disarm, the Security Council would decide at a future, second stage whether to authorize the use of force. ${ }^{178}$ In

${ }^{177}$ See, e.g., Hofmann, supra note 19, at 22-29 (discussing the linguistic ambiguity in Resolution 1441).

${ }^{178}$ UN Doc. S/PV.4644 at 5 (Nov. 8, 2002) (France) (asserting that if UNMOVIC and IAEA report that Iraq is in noncompliance, "the Council would meet immediately to evaluate the seriousness of the violations and draw the appropriate conclusions. France welcomes the fact that all ambiguity on this point and all elements of automaticity have disappeared from the resolution."); id. at 6 (Mexico) ("We welcome the fact that a two-stage approach has been accepted. ... We reiterate the belief reflected in the agreed text that the possibility of the use of force is valid only as a last resort, with prior explicit authorization required from the Security Council."); id. at 7 (Ireland) ("We have noted carefully and we welcome the assurances given by the sponsors that their purpose in presenting this resolution was to achieve disarmament through inspections, and not to establish a basis for the use of military force. . . The resolution provides for a clear sequential process. ... As far as Ireland is concerned, it is for the Council to decide any ensuing action."); $i d$. at 8 (Russia) ("As a result of intensive negotiations, the resolution just adopted contains no provisions for the automatic use of force. It is important that the resolution's sponsors today officially confirmed in the Security Council that that is their understanding ... ."); id. at 9 (Bulgaria) ("This resolution is not a pretext for automatic recourse to the use of force. ... My country welcomes the fact that the resolution categorically reaffirms the centrality of the Security Council in our decision-making process."); id. at 10 (Syria) ("Syria voted in favour of the resolution, having received reassurances from its sponsors, the United States and the United Kingdom, and from France and Russia through high-level contacts, that it would not be used as a pretext for striking against Iraq and does not constitute a basis for any automatic strikes against Iraq. The resolution should not be interpreted, through certain paragraphs, as authorizing any State to use force. It reaffirms the central role of the Security Council in addressing all phases of 
the Iraqi issue."); $i d$. at 11 (Colombia) ("We insisted on preserving the central role of the Security Council, as clearly stipulated in paragraphs 4,11 and 12 . This resolution is not, nor could it be at this time, a resolution to authorize the use of force."); id. at 11 (Cameroon) ("My country welcomes the clear statements just made by the sponsors, spelling out the fact that the resolution just adopted, on their initiative, does not contain traps or atomaticity. Along with us, they confirm today, ... that they are working, and will always work, for the centrality of the Security Council in the maintenance of international peace and security."); id. at 12-13 (China) ("China supports the two-stage approach. The Chinese delegation actively participated at all stages of the consultations on the draft resolution .... As the sponsors pointed out in their 
reaction to these concerns, and in an effort to placate them, the U.K. representative stated to the Security Council:

statements earlier, the purpose of the resolution is to achieve the disarmament of Iraq through effective inspections. The text no longer includes automaticity for authorizing the use of force. According to the resolution that has just been adopted, only upon receipt of a report by UNMOVIC and the IAEA on Iraq's non-compliance and failure to cooperate fully in the implementation of the resolution, will the Security Council consider the situation and take a position.") 
We heard loud and clear during the negotiations the concerns about "automaticity" and "hidden triggers"- the concern that on a decision so crucial we should not rush into military action; that on a decision so crucial any Iraqi violations should be discussed by the Council. Let me be equally clear in response, as a co-sponsor with the United States of the text we have just adopted. There is no "automaticity" in this resolution. If there is a further Iraqi breach of its disarmament obligations, the matter will return to the Council for discussion as required in paragraph 12 . We would expect the Security Council to then meet its responsibilities. ${ }^{179}$

${ }^{179}$ Id. at 4-5. 
The U.S. representative echoed this assertion that "the resolution contains no 'hidden triggers' and no 'automaticity' with respect to the use of force." At the same time, the U.S. representative asserted that "[i]f the Security Council fails to act decisively in the event of further Iraqi violations, this resolution does not constrain any Member State from acting to defend itself against the threat posed by Iraq or to enforce relevant United Nations resolutions and protect world peace and security." "180 The only way to square the two statements by the United States is to argue that Resolution 1441 does not "automatically" authorize or "trigger" the use of force because, after reports by UNMOVIC and the IAEA regarding Iraqi compliance, there must first be a further "consideration" at (but not decision by) the Security Council before force is used. Yet that interpretation seems rather meaningless, since there were several "considerations" at the Security Council from December 2002 onward regarding the situation in Iraq after reports by the UNMOVIC and the IAEA to the Security Council that questioned Iraqi compliance, ${ }^{181}$ if such a "consideration" was the only prerequisite for permission to use force in Iraq, then Resolution 1441 would appear to

${ }^{180} I d$. at 3.

${ }^{181}$ For example, in December 2002, the head of UNMOVIC reported to the Security Council that, with respect to the declaration submitted by Iraq as required by Resolution 1441 ,"[i]n a few cases there is information in our possession that would appear to contradict Iraq's account. . . . [T] here are indications suggesting that Iraq's account of its production and unilateral destruction of anthrax during the period between 1988 and 1991 may not be accurate." UNMOVIC News Release, Notes for Briefing the Security Council Regarding Inspections in Iraq and a Preliminary Assessment of Iraq's Declaration under Paragraph 3 of Resolution 1441 (2002), Dr. Hans Blix, Executive Chairman of UNMOVIC (Dec. 19, 2002), at $<$ http://www.un.org/depts/unmovic $>$. In January 2003, he reported: "Iraq appears not to have come to genuine acceptance — not even today — of the disarmament, which was demanded of it and which it needs to carry out to win the confidence of the world and to live in peace." See Executive Chairman of UNMOVIC, Dr. Hans Blix, An Update on Inspection (Jan. 27, 2003), at $<$ http://www.un.org/Depts/unmovic/Bx27.htm>; see also Julia Preston, U.N. Inspector Says Iraq Falls Short on Cooperation, N.Y. TIMES, Jan. 28, 2003, at A1. 
be a "hidden trigger." The U.S. interpretation is less meaningless if it envisages a more formal, written report by UNMOVIC and the IAEA, whereby those entities expressly assert to the Security Council, in accordance with either paragraphs four or eleven of Resolution 1441, that Iraq has made false statements in its declaration or has interfered with inspection activities, but then the problem becomes (as noted below) that UNMOVIC and the IAEA never made such a formal report. Further, this interpretation essentially places in the hands of UNMOVIC and the IAEA the ability to trigger an authorization to use force, which may not be a "hidden" trigger, but it is a trigger over which the Security Council had no control, and thus appears inconsistent with the concerns of the other Security Council members. In any evert, whatever meaning might be ascribed to the U.S. position, all members of the Security Council other than the United States (and arguably the United Kingdom) who spoke to the issue when Resolution 1441 was adopted were emphatic that the resolution meant that force would only be used after a further Security Council decision.

Within the thirty days required by Resolution 1441, Iraq submitted an almost 12,000 page declaration to the United Nations that Iraqi officials asserted contained "currently accurate, full and complete" details about Iraq's chemical, biological, and nuclear programs. ${ }^{182}$ The declaration maintained that Iraq had no weapons of mass destruction. After UNMOVIC inspectors had deployed to Iraq for a few weeks, UNMOVIC conceded that its investigators had uncovered no "smoking gun" evidence that Iraq had resumed secret WMD programs. ${ }^{183}$ With no such evidence, with

${ }^{182}$ See Rajiv Chandrasekaran, Baghdad Delivers Weapons Data to U.N., WASH. Post, Dec. 8, 2002, at A1.

${ }^{183}$ See Executive Chairman of UNMOVIC, Dr. Hans Blix, An Update on Inspection (Jan. 27, 2003), at $<\mathrm{http}$ //www.un.org/Depts/unmovic/Bx27.htm>; see also Colum Lynch, No 
UNMOVIC and IAEA inspectors operating without any restrictions in Iraq, and with Iraq professing its willingness to cooperate in resolving any alleged discrepancies in its declaration, ${ }^{184}$ support by other governments for the resort to armed force against Iraq weakened. ${ }^{185}$ France declared that it supported full and effective disarmament of Iraq by peaceful means through use of the inspectors, but would oppose military action against Iraq — and would veto any Security Council resolution authorizing such force - if such means were not exhausted. ${ }^{186}$ Germany joined France in opposition to the resort to war prior to exhausting all efforts at inspections. ${ }^{187}$ Russia, too, announced that it was ready to use its veto power to block a Security Council resolution authorizing the use of force under

"Smoking Guns" So Far, U.N. Is Told, Wash. Post, Jan. 10, 2003, at A1; Julia Preston, U.N. Inspector Says Iraq Falls Short on Cooperation, N.Y. TIMES, Jan. 28, 2003, at A1. In his report on January 27, Dr. Blix stated: "Iraq appears not to have come to genuine acceptance - not even today - of the disarmament, which was demanded of it and which it needs to carry out to win the confidence of the world and to live in peace."

The inspectors did uncover some evidence of Iraqi non-compliance. For example, the inspectors discovered missiles with a range in excess of 180 kilometers, in violation of Security Council resolution 687. See Julia Preston \& Eric Schmitt, Experts Confirm New Iraqi Missile Exceeds U.N. Limit, N.Y. TIMES, Feb. 13, 2003, at A1. Thereafter, Iraq began destroying the missiles. See Rajiv Chandrasekaran, Iraq to Destroy Illegal Missiles, WASH. Post, Mar. 1, 2003, at A1.

${ }^{184}$ See, e.g., Rajiv Chandrasekaran, Iraq Vows More Cooperation on Inspections, WASH. Post, Jan. 29, 2003, at A13.

${ }^{185}$ See Michael Dobbs, Allies Slow U.S. War Plans, WASH. Post, Jan. 11, 2003, at A1.

${ }^{186} \mathrm{See}$ Gov't of France News Release, Réunion du conseil de securité des nations unies au niveau ministériel sur la lutte contre le tèrrorisme-Conférence de presse du ministre des affaires étrangères, M. Dominique de Villepin (Jan. 20, 2003), at $<$ http://www.doc.diplomatie.gouv.fr>; Glenn Kessler \& Colum Lynch, France Vows to Block Resolution on Iraq War, WASH. POST, Jan. 21, 2003, at A1.

${ }^{187}$ See F.R.G. News Release on Schröder: Krieg darf nie unausweichlich sein (Jan. 23, 2003), at $<\mathrm{http}: / /$ www.bundesregierung.de $>$; John Tagliabue, France and Germany Draw a Line, Against Washington, N.Y. TIMES, Jan. 23, 2003, at A10. 
the existing circumstances. ${ }^{188}$

${ }^{188}$ See John Tagliabue, France and Russia Ready to Use Veto Against Iraq War, N.Y. TiMES, Mar. 6, 2003, at A1. 
On February 24, 2003, Spain, the United States, and the United Kingdom circulated a draft resolution in which the Security Council would decide "that Iraq has failed to take the final opportunity afforded to it in Resolution 1441 (2002)", ${ }^{189}$ precisely the measure expected as part of a "two-stage" process. President Bush asserted that "[n]o matter what the whip count is, we're calling for the vote. We want people to stand up and say what their opinion is about Saddam Hussein and the utility of the United Nations Security Council." ${ }^{190}$ However, the three states withdrew the resolution by mid-March in the face of an inability even to obtain nine votes, let alone the concurrence or abstention of the other permanent members. ${ }^{191}$ No written reports were made by

${ }^{189}$ See U.S.-British Draft Resolution Stating Position on Iraq, N.Y. TIMES, Feb. 25, 2003, at A10. 2003)

190 The President's News Conference, 39 WeEKLy Comp. Pres. Doc. 295, 301 (Mar. 6,

${ }^{191}$ See Gov’t of France News Release on Entretien du President de la Republique, M. Jacques Chirac, avec "TF1" et "France 2" (Mar. 10, 2003), at <http://www.diplomatie.gouv.fr > ("A ce moment-là, la France votera non.") (“At that time, France will vote no."); Elaine Sciolino, France to Veto Resolution on Iraq War, Chirac Says, N.Y. Times, Mar. 11, 2003, at A8; F.R.G. News Release on Gemeinsame Erklärung von Russland, Deutschland und Frankreich (Mar. 5, 
either UNMOVIC or the IAEA pursuant to Resolution 1441 paragraphs four and eleven that Iraq had made false statements or omissions in its WMD declaration, nor that Iraq had interfered with inspection activities. Having received no such reports, the Security Council did not "convene immediately" so as to "consider the situation" as contemplated by paragraph twelve of Resolution 1441. Nevertheless, in March 2003, the United States launched its invasion of Iraq.

2003), at $<\mathrm{http}: / /$ www.bundesregierung.de $>$ (joint statement by France, Germany, and Russia that "[i]n diesem Zusammenhang werden wir keinen Resolutionsentwurf passieren lassen, der eine Gewaltanwendung genehmigen würde.") ("In this regard, we will not allow any draft resolution to be adopted that would permit the use of force."). 
As noted above, the discussions surrounding Resolution 1441 largely reflect a belief by the Security Council membership that legal authority did not already exist to use force against Iraq for implementation of Resolution 687. Moreover, when the United States and United Kingdom articulated their legal theory at the time of the invasion, some Security Council members denied that such legal authority existed, ${ }^{192}$ while others rejected the impending military action without specifying whether their concerns were on policy grounds or legal grounds. ${ }^{193}$ Further, many other governments strongly disfavored the intervention on legal and policy grounds. ${ }^{194}$ Although of less

192 See UN Doc. S/PV.4721 at 8 (Mar. 19, 2003) (statement of Russia) ("Not one of those [Security Council] resolutions authorizes the right to use force against Iraq outside the Charter of the United Nations; not one of them authorizes the violent overthrow of the leadership of a sovereign State."); id. at 9 (Syria) ("With the unanimous adoption by the Security Council of resolution 1441 (2002), basic international terms of reference were set out to settle the Iraqi question. The verbatim record of meetings of the Security Council include comments by those members that are hastening to wage war against Iraq, confirming their belief that that resolution does not allow for international law to be circumvented or to permit a strike against Iraq without first reverting to the Security Council"); UN Doc. S/PV.4726 (resumption 1) at 26-28 (Mar. 27, 2003) (statement of Russia); id. at 28 (statement of China); id. at 32 (Syria); Felicity Barringer, Critics Say U.S. Lacks Legal Basis for Attack, N.Y. Times, Mar. 20, 2003, at A19; Keith B. Richburg, French See Iraq Crisis Imperiling Rule of Law, WASH. Post, Mar. 6, 2003, at A19.

193 See UN Doc. S/PV.4721 at 4 (Germany) ("Germany emphatically rejects the impending war. .. . The majority of Security Council members believe that there are no grounds now for breaking off the disarmament process carried out under the supervision of the United Nations"); id. at 12 (Mexico) ("We are convinced that with [UNMOVIC and the IAEA], the United Nations could have brought about the peaceful disarmament of Iraq.")

194 See, e.g., UN Doc. S/PV.4726 at 7 (Mar. 26, 2003) (statement of Malaysia, as Chair of the coordinating bureau of the non-aligned movement) ("The war against Iraq has been carried out without the authorization of the Security Council. This war is being carried out in violation of the principles of international law and the Charter."); id. at 17 (Libya) ("We point out that 11 Council members were opposed to military action; 116 Non-Aligned Movement countries and 57 countries from the Organization of the Islamic Conference were all opposed to the use of force, because it represented a threat to their States and to international peace and security."); id. at 19 (Indonesia) ("Indonesia has strongly deployed the unilateral action by the United States of America and its allies, who have decided to launch a military attack against Iraq in contravention of international law."); id at 24 (India) ("we sincerely hope that the military campaign, which 
relevance when assessing the proper interpretation of a Security Council resolution or of the UN Charter, the Secretary-General asserted just prior to the invasion that "[i]f the US and others were to go outside the Council and take military action it would not be in conformity with the Charter"195 and there was considerable adverse public reaction in many states. ${ }^{196}$ At the same time, the United States asserted in late March that some forty-four nations were part of the coalition supporting the invasion of Iraq. ${ }^{197}$

was unjustified and avoidable, will be short-lived"); $i d$. at 28 (Brazil) ("Brazil can only profoundly deplore the initiation of military action and, in particular, the fact that force has been used without the express authorization of the Security Council"); id. at 30 (Switzerland) (lamenting that "a military intervention has been launched against Iraq without the explicit authorization of the" Security Council); Letter Dated 24 March 2003 from the Permanent Observer of the League of Arab States to the United Nations Addressed to the President of the Security Council, UN Doc. S/2003/365* (Mar. 26, 2003) (containing resolution adopted on March 24 by the Council of Ministers of the League of Arab States calling for immediate cessation of acts of war and withdrawal of foreign forces from Iraq); Susan Sachs, Arab Foreign Ministers Urge U.S. Withdrawal, N.Y. TIMES, Mar. 25, 2003, at B11.

${ }^{195}$ Press Conference, UN Secretary-General Kofi Annan, The Hague, The Netherlands (Mar. 10, 2003), at $<$ http://www.un.org/apps/sg/printoffthecuff.asp?nid=394\#> (unofficial transcript).

${ }^{196}$ See Robert J. McCartney, Opponents of War Decry U.S. Stance, WASH. Post, Mar. 19, 2003, at A17; Across Europe, Millions Protest a War in Iraq, WASH. Post, Mar. 15, 2003, at A17; Emily Wax, Thousands Protest Across Arab World, WASH. Post, Mar. 22, 2003, at A28; Glenn Frankel, Thousands Protest Across Europe, Asia, WASH. Post, Mar. 23, 2003, at A28.

${ }^{197}$ See U.S. Dep't of State Press Release on White House Releases List of More than 40 Coalition Members (Mar. 20, 2003), at $<$ http://usinfo.state.gov/regional/nea/iraq/text2003/0320list.htm>; Glenn Kessler, United States Puts a Spin on Coalition Numbers, WASH. Post, Mar. 21, 2003, at A29. For example, Singapore took the view:

Like many [UN] Members, we would preferred that the Security Council had against explicitly authorized military action to disarm Iraq. But the onus was always on Iraq to avoid war. Given Iraq's long history of flouting Security Council resolutions, Singapore's view was that the Council's inability to reach a new consensus could not be taken as a reason for inaction to disarm Iraq. 
UN Doc. S/PV.4726 at 26 (Mar. 26, 2003); see id. at 39 (Japan) ("Japan has come to the conclusion that, as a responsible member of the international community, it supports the actions taken by the United States and its coalition partners."); id. at 46 (Iceland) (supporting the coalition). 
Unlike in 1993, there was no formal or informal mandate agreed upon behind Security Council closed doors that the invasion was permissible. As with the case of the 1998 attacks, those supporting the legality of the attack advanced the "revival" theory as allowing the states on their own initiative to attack, and the inability to obtain the Security Council's political blessing as simply unfortunate. Yet, a key difference in 2003 from 1998 was the existence of Resolution 1441, in which the Security Council created a fairly specific and highly intrusive process for addressing Iraq's noncompliance ${ }^{198}$ and — notwithstanding strenuous efforts by the United States in New York and in

${ }^{198}$ See S/PV.4644 at 3 (Nov. 8, 2002) (statement by U.S. representative to the United Nations) ("The resolution gives [UNMOVIC and IAEA] a new powerful, mandate. Its core is immediate and unimpeded access to every site, including presidential and other remote sites, structure or vehicle they choose to inspect and equally immediate and unimpeded access to people they wish to interview."). By contrast, the 1998 UN-Iraq memorandum of understanding on the conduct of weapons inspections contained special procedures limiting inspections with respect to several "presidential sites" (which consisted of several hundred buildings). See Memorandum of Understanding between the United Nations and the Republic of Iraq (Feb. 23, 1998), attachment to Letter Dated 25 February 1998 from the Secretary-General Addressed to the President of the Security Council, UN Doc. S/1998/166 (1998); Christopher S. Wren, "Presidential Sites": How Many, and How Big?, N.Y. Times, Feb. 16, 1998, at A8. 
capitals worldwide - pointedly refused to authorize the use of force as a part of that process. Such an omission in this sequence of steps is a basis for saying that the authorization is excluded (expressio unius est exclusio alterius). ${ }^{199}$ Moreover, several Security Council members apparently believed that Resolution 1441 reflected an important change in the Security Council's approach to the use of force against Iraq that had arisen in the 1990's. As Mexico stated, "this resolution also constitutes progress, as it eliminates the concept of automaticity in the use of force in response to a serious violation without the explicit agreement of the Council.",200

${ }^{199}$ Accord Conditions of Admission of a State to the United Nations (Charter, Art. 4), supra note 120 , at 62-63; IMCO case, supra note 22 , at 158-60.

${ }^{200}$ S/PV.4644 at 6 (Nov. 8, 2002). 
Indeed, ultimately the issue was not Iraqi compliance with Resolution 687; it was Iraqi compliance with Resolution $1441 .{ }^{201}$ However one might have interpreted the authorization to use force based on Resolutions 678, 686, and 687 standing alone, or might have interpreted them in light of the Security Council's apparent "mandate" in 1993, it is hard to escape the overwhelming opposition to the use of force among the Security Council members in 2002-2003 when operating under Resolution 1441. Certainly the tone of Resolution 1441 was in the nature of a threat to Iraq: the resolution recalled Resolution 678 on the use of force; declared Iraq to be in breach of Resolution 687; and provided Iraq "one final opportunity" before it "will face serious consequences." Yet that threat is fully consistent with a concomitant intention for further Security Council authorization at a future date, once the Security Council determines that the final

${ }^{201}$ President Bush himself acknowledged this when he stated on the eve of the invasion: "The world needs [Iraqi President Saddam Hussein] to answer a single question: Has the Iraqi regime fully and unconditionally disarmed, as required by Resolution 1441, or has it not?" President Bush News Conference, 39 WeEkly CoMP. Pres. Doc. 295, 296 (Mar. 10, 2003 ). 
opportunity has passed. ${ }^{202}$

${ }^{202}$ Accord Gefahrlicher Bummerang-Effekt, DeR SPIEGEL 48, Nov. 25, 2002 (interview with German Professor Bruno Simma, who is currently serving as a judge on the International Court of Justice). 
The United States and the United Kingdom walked away from the passage of Resolution 1441 asserting that no language was included requiring further Security Council authorization, ${ }^{203}$ but it is equally true that no language was included in the resolution granting Security Council authorization. Both those members favoring and disfavoring an authorization to use force in Resolution 1441 sought to include language expressly reflecting their positions; neither side succeeded and in this sense the resolution was left intentionally ambiguous. The result, however, was a new regime under Resolution 1441 that did not contain an authorization to use force, such that the default rule (no use of force) ${ }^{204}$ remained intact. Moreover, even if one regards the language of Resolution 1441 as in some sense ambiguous or unclear, the language should be interpreted in accordance with the core principle underlying Chapter VII of the UN Charter, which is the utilization of collective decision-making for addressing threats to international peace and security. The fact that the Security Council proved unable to reach agreement in March 2003 either to use force or to continue with weapons inspections, does not mean that states were free to act in the face of a Security Council "deadlock." Although some scholars have argued otherwise, ${ }^{205}$ contemporary legal restraints on the unilateral use of force do not dissipate whenever the Security Council's fails

${ }^{203}$ See, e.g., UK Attorney-General Analysis, supra note 10 (stating that the paragraph affording Iraq one final opportunity to comply "does not, however, mean that no further action can be taken without a new resolution of the Council. Had that been the intention, it would have provided that the Council would decide what needed to be done to restore international peace and security, not that it would consider the matter.")

${ }^{204}$ See UN CHARTER, art. 2(4).

${ }^{205}$ See, e.g., Myres McDougal \& W. Michael Reisman, Rhodesia and the United Nations: The Lawfulness of International Concern, 62 AM. J. INT'L L. 1 (1968); W. MiCHAEL Reisman, NulLity AND REVISION 848-49 (1971). 
to reach consensus. ${ }^{206}$

Taken all together, how should one assess these incidents of Security Council practice since 1991? With the benefit of a decade of hindsight, three features of the 1993 incident seem to stand out. First, the 1993 incident is probably best interpreted as a Security Council (and, more broadly, global community) tolerance of low-level uses of force by states tied closely to Iraq's interference with specific UN activities associated with Resolution 687 . When read together with the Security Council's reactions in 1998 and 2002-2003, there does not appear to be any blanket endorsement by the Security Council at any point for the wide-ranging use of force against Iraq on the scale of invading and occupying the country, let alone toppling its government.

${ }^{206}$ See, e.g., Murphy, Force and Arms, supra note 25, at 271 (asserting that "[t]his claim has not been accepted by most scholars or reflected in state practice."); Corfu Channel (U.K. v. Alb.), 1949 ICJ REP. 4, 35 (Apr. 9) (finding that operational defects in the ability of the United Nations to address collective security concerns cannot support a return to a right of self-help or unilateral enforcement of international law). 
Second, the tolerance of these low-level uses of force in 1993 and, to a lesser extent, in 1998 was no doubt influenced by the extensive and intrusive engagement of the international community in Iraq from 1990 onward, whether it related to the imposition of economic sanctions, the "oil-forfood" program exception to those sanctions, ${ }^{207}$ the UN Compensation Commission program, weapons inspections, or the demilitarized zone in Iraq. Indeed, throughout the 1990's, foreign military forces continued to deny access to large portions of Iraqi territory in the north and south by Iraqi fixed wing aircraft, and military force was periodically used by states—principally through

${ }^{207}$ To address concerns about the needs of the Iraqi people under the UN sanctions regime, the Security Council adopted an "oil-for-food" program, see SC Res. 986 (Apr. 14, 1995), which came into effect in December 1996. Under the program, the United Nations became deeply involved in financial transactions between importers of Iraqi oil, including the deposit of the proceeds of that oil into a UN escrow account, the payment from that account to exporters of food and other humanitarian goods to Iraq, and the monitoring of the distribution in Iraq of those goods. The program was revised various times. See, e.g., SC Res. 1409 (May 14, 2002) (revising procedures for the "goods review list"). 
missile and aircraft attacks against Iraqi bunkers and missile batteries - to maintain those areas as safe zones for Iraqi Kurds and Shiites. This tolerance by the global community, however, was predicated on an understanding that the force was being used not in a manner to alter Iraqi territory or its government but, rather, as principally a humanitarian measure necessary to protect the lives of Iraqi nationals.

Third, while the 1993 incident may stand for the proposition that the Security Council members can endorse a use of force that has a dubious pedigree in prior Security Council resolutions, it does not necessarily follow that states may invoke that dubious pedigree on their own authority. Rather, in the face of a highly visible effort to obtain a mandate from the Security Council that failed due to a belief among the majority of the members that alternatives to the use of force were preferable, the reliance on the Resolution 678/687 theory transitions from being dubious to being unpersuasive. Indeed, to the extent that one views the Security Council's authorization for the use of force as flowing from UN Charter Article 42, that provision calls for a Security Council determination that non-forcible measures "would be inadequate or have proved to be inadequate." When Resolution 678 was initially passed, some governments and observers argued that the Security Council made no such formal determination, but at that time it could be reasonably inferred that, by expressly authorizing the use of force, the Security Council "impliedly recognized that sanctions would not prove adequate to compel Iraqi withdrawal. ${ }^{208}$ In 2003, however, no such inference was possible since the Security Council did not expressly authorize the use of force, nor decide that the sanctions maintained by Resolution 687 to coerce Iraqi compliance with its WMD obligations had failed. The Security Council did declare in November 2002 that Iraq was in material breach of its

${ }^{208}$ Schachter, supra note 35, at 462. 
obligations, but any inference that might be drawn from that declaration must take account of the clear position of the majority members of the Security Council that use of force was not authorized.

\section{E. The Outer Limit of Security Council Legitimization}

The legal theory advanced by the United States may help demarcate the outer limit of an evolution that began shortly after adoption of the UN Charter in 1945, in which the major powers have sought to alter the terms by which UN collective security operates so as to cloak their actions with UN authority. The original scheme of the Charter envisaged national forces being made available to the United Nations "on-call" pursuant to agreements between cooperating states and the United Nations under UN Charter Article 43. ${ }^{209}$ A UN military staff committee, comprised of the chiefs of staff (or their representatives) of the permanent members was established to advise the Security Council on the deployment of those forces. ${ }^{210}$

\footnotetext{
${ }^{209}$ UN CHARTER, art. 43.

${ }^{210}$ Id. at arts. $45-47$.
} 
As is well-known, the scheme foundered right from the start, with the major powers unwilling to give up their comparative military advantage for use by the global community. Instead, military forces were only made available to the United Nations on an ad hoc basis for the purpose of peacekeeping operations, or were deployed under national authority with the blessing of the United Nations for peace enforcement operations. Given that these types of actions were detached from the clear language of the Charter, their "legitimacy" 211 tended to be a function of three factors;

${ }^{211}$ See generally Tetsuo Sato, The Legitimacy of Security Council Activities Under Chapter VII of the UN Charter Since the End of the Cold War, in THE LEGITIMACY OF InTERNATIONAL ORGANIZATIONS 309 (Jean-Marc Coicaud \& Veijo Heiskanen eds., 2001); Kirgis, supra note 127, at 519-20; David D. Caron, The Legitimacy of the Collective Authority of the Security Council, 87 AM. J. INT'L L. 552 (1993). For a highly developed theory of legitimacy in international law, see ThOMAs M. FrANCK, THE POWER OF LEGITIMACY AMONG NATIONS (1990); THOMAS M. FrANCK, FAIRNESS IN INTERNATIONAL LAW AND INSTITUTIONS (1995). According to Professor Franck, a rule (or a rule-making institution) will "pull toward compliance" those states that it addresses when it is perceived as "legitimate" and "fair". Legitimacy turns on four "objective" elements: determinacy, symbolic validation, coherence, and adherence. Fairness turns on whether the rule is just, which in turn requires a balancing of different variables, including traditional notions of equity in international law. Professor 
(1) the degree to which the action could be anchored in some plausible interpretation of the UN Charter; (2) the degree of consensus among the Security Council members (or possibly the General Assembly) that the action was permissible; and (3) the degree to which the action avoided intruding upon the political independence and territorial sovereignty of a UN member state. Where there was a high degree of all three factors, the action attracted a high degree of legitimacy; where one or more factors were minimal, the action was viewed as less legitimate.

Thus, when the Korean crisis emerged in 1950, the original Charter scheme was jettisoned in favor of an approach whereby national military forces were left within the control of national authorities, under the unified command of the United States. At the same time, extensive efforts were made, through a combination of Security Council and General Assembly resolutions, to anchor the deployment of the forces within those organs' authority to address international peace and security under Chapters VI and VII, a perception enhanced by allowing the forces to use the UN

Schachter, however, has doubts about subjecting the substantive decisions of a political organ (such as the Security Council) to such criteria, on grounds that "[w] hat is important for those organs are the national interests and values at stake, the expectations of the members and the costs of proposed measures." Oscar Schachter, The UN Legal Order: An Overview, in 1 UNITED NATIONS LEGAL ORDER, supra note 25, 1 at 14. 
flag. While the return of the Soviet Union to the Security Council prevented further action being taken in that organ, support outside the Soviet bloc for the deployment was strong both in the Security Council and (using the Uniting for Peace Resolution) in the General Assembly. There was considerable debate among states as to "how far" the enforcement action should go in intruding upon North Korean political structures—-with some consideration given to the unification of Korea—and there were states that believed the United Nations had no authority to take such action. Ultimately, the conflict ended with North and South Korea arrayed largely along the same border as existed when the war commenced, leaving intact North Korea's political independence and territory. With the confluence of these factors at a reasonably high level — a plausible use of the UN Charter, agreement in the Security Council or General Assembly, and a decision not to alter the territorial or institutional structures of the targeted state - the action had a relatively high degree of legitimacy. At the same time, and continuing up to the present, the United Nations launched dozens of peacekeeping operations, anchored somewhere in Chapters VI and VII, supported by decisions of the Security Council (and occasionally the General Assembly), and respectful of the sovereignty of the host state(s), whose consent was considered necessary for the deployment of the lightly-armed "blue helmets." Such actions secured a high degree of legitimacy as well.

But how far could the Security Council go in launching force on behalf of the United Nations? Protection of human rights was viewed as a basis for deploying force against Southern Rhodesia in 1966, with the force even undertaken by a single state (the United Kingdom) operating under its own flag rather than by a coalition. ${ }^{212}$ Such protection of human rights was not squarely

${ }^{212}$ See SC Res. 221 (Apr. 9, 1966). In Resolution 217, the Security Council determined that the unilateral declaration of independence by the minority regime in Southern Rhodesia constituted a threat to international peace and security, and recommended that states refrain from 
contemplated in Chapter VII, nor the complete delegation of Chapter VII power to a state operating in its national capacity. Yet, at the same time, the action was squarely endorsed by the Security Council and the force to be used was limited to the maritime interdiction of those oil tankers calling at the Mozambique port of Beira that were reasonably believed to be carrying oil destined for Southern Rhodesia - a use of force far short of the invasion of territory. On balance, the action was viewed as legitimate.

providing arms to, and break all economic relations with, Southern Rhodesia. SC Res. 217 (Nov. 20, 1965). Moreover, Resolution 217 recommended that the United Kingdom act to quell the rebellion by that regime. In Resolution 221, the Security Council determined that the situation constituted a threat to the peace and directed the United Kingdom "to prevent, by use of force in necessary" oil destined for Southern Rhodesia. Mandatory economic sanctions were thereafter imposed by SC Res. 232 (Dec. 16, 1966) and then, upon the establishment of Zimbabwe, were terminated by SC Res. 460 (Dec. 21, 1979). 
With the demise of the Cold War, once again the Security Council unleashed a coalition of national forces against an aggressor, and while some doubts were expressed about the legitimacy of expelling Iraq from Kuwait, ${ }^{213}$ the action was widely accepted as legitimate. ${ }^{214}$ The use of force was plausibly anchored in Chapter VII, it was expressly authorized by the Security Council, and it was only pursued for the purpose of expelling Iraq from Kuwait. From that authorization, in just a handful of years, flowed other authorizations to use force that had nothing to do with combating invaders but, rather, with matters such as preventing human rights abuses (e.g., Bosnia, Rwanda), restoring a democratically-elected government (e.g., Haiti), or otherwise intervening in internal conflicts (e.g., Liberia, Somalia). ${ }^{215}$ These matters were much less clearly anchored in the text (or, for that matter, the negotiating history) of the Charter, and thus raised some questions among states and scholars as to their legitimacy. Yet the actions occurred with the express approval of the Security Council after it had weighed all the relevant factors: the facts underlying the threat to peace or to human dignity; the threat to sovereignty if force were unleashed; and the proportionality and

${ }^{213}$ See, e.g., Burns H. Weston, Security Council Resolution 678 and Persian Gulf Decision Making: Precarious Legitimacy, 85 AM. J. INT’L L. 516 (1991) (arguing that the method of authorizing states in their national capacity to use military force raises legitimacy concerns).

${ }^{214}$ See Gray, From Unity to Polarization, supra note 155, at 3 (finding that "there is a consensus that it is for the Security Council to authorize Member States to take enforcement action, even if the precise legal basis for this in the Charter is not clear.").

215 See generally ENFORCING RESTRAINT: COLLECTIVE INTERVENTION IN INTERNAL CONFLICT (Lori Fisler Damrosch ed., 1993); CHRISTINE GRAY, INTERNATIONAL LAW AND THE USE OF ForCE chs. 6 \& 7 (2000); Yoram Dinstein, WAR, AGGRESSION AND SELF-DEFENCE 261-263 (3d ed. 2001) ("It is manifest from the spate of resolutions that the Security Council currently interprets its mandate under Chapter VII in the most liberal manner."). 
necessity of the action. ${ }^{216}$ While these actions intruded deeply into the internal affairs of the targeted state, they also often occurred in the context of either a collapse of government authority (e.g., Somalia) or a clearly illegitimate government (e.g., Haiti). As such, although the Security Council may have been "pushing the envelope" of its authority, few condemned the interventions.

${ }^{216}$ Professor Franck has referred to this role of the Security Council as akin to being a "jury" of states' resort to the use of force. See FRANCK, supra note 35, at 134. 
The Security Council may have reached the outer limits of its ability to legitimize the use of force, however, with its informal or implied blessing of uses of force, as seen with respect to the U.S. action against Iraq in $1993 .{ }^{217}$ Such force was not in response to a blatant act of aggression (although it did concern minor border incursions), nor was it expressly authorized by a Security Council resolution. However, the 1993 attacks had the informal approval of the Security Council and was a use of force designed not to intrude excessively into Iraqi sovereignty. As such, the use of such force received relatively little criticism as compared, for example, to the U.S. bombing of Tripoli in $1986 .{ }^{218}$

With the invasion of Iraq in 2003, the U.S. effort to cloak its actions in the aura of the Security Council appears to have crossed over the legitimacy barrier. The United States sought, but failed to obtain, express Security Council authorization for its use of force. The United States

${ }^{217}$ For an example of such a statement with respect to the intervention of West African states in Liberia in 1991, see Note by the President of the Security Council, UN Doc. S/22133 (Jan. 22, 1991) (stating that the "members of the Security Council commend the efforts made by" East African states for invading Liberia to stop the carnage there).

${ }^{218}$ See 1986 U.N.Y.B. 247. 
sought, but failed to obtain, informal or tacit Security Council acceptance of its use of force. Perhaps most striking given its status as a veto-wielding permanent member of the Security Council, the United States even sought to obtain a vote at the Security Council that would garner nine affirmative votes, even if the resolution failed due to a veto by China, France, or Russia. That effort, too, failed. Consequently, operating on the fringes of authorization as contemplated by the UN Charter, with a strong expression of disapproval by the Security Council members (though obviously no Security Council resolution prohibiting the action), and in a manner designed to overthrow an existing government, the United States ultimately generated a widespread public perception that the action was illegitimate. In other words, even if one believes that the U.S. legal theory was valid —that by some alchemy involving past Security Council resolutions, and perhaps even backroom winks and nods, Security Council authorization existed - the U.S. legal theory was so reliant on a complex, nuanced interpretation of often opaque and sometimes contradictory language that, in the face of strong opposition by other Security Council members at the time of the invasion, the legitimacy that would otherwise attach to a Security Council authorization was completely dissipated. The Security Council's mandate for authorizing the use of force could be stretched over fifty years considerably beyond what was envisaged in 1945 but, notwithstanding clever lawyering, it could only be taken so far-even by the world's pre-eminent superpower.

The unwillingness of the global community to see the Security Council's mandate pressed beyond a certain point is a positive development, in that it helps maintain a certain integrity to the UN process of authorizing the use of force. The collective security machinery of the Charter cannot be viewed as so malleable that a few states, even if major powers, may use it as they wish. Indeed, "the effectiveness of the Security Council depends very heavily on the respect in which it is held by 
member states. ${ }^{, 219}$ For the Charter and the deliberative process of the Security Council to have meaning, authorizations to use force generally should be made formally, especially when the force is highly intrusive, such as the ouster of a government from power. But if an authorization is made informally, or is to be divined from elaborate legal theories, then at a minimum it should be made with the backing or acquiescence of the Council. Were the invasion of Iraq in 2003 to have received global approval in the face of disapproval of the majority of the members of the Security Council, including three of its permanent members, then the "currency" of Security Council approval would have been vastly deflated.

Indeed, future authorizations by the Security Council for the use of military force may gain a greater legitimacy due to the Council's unwillingness in March 2003 to bend to the will of a major power in a situation where the majority of Council members believed that a use of force was inappropriate. At the same time, future authorizations for states to use force outside UN command must confront a central problem that arose from the U.S. legal theory: indeterminate Security Council resolutions provide opportunities for loose interpretations of Security Council authority by those states. The aggressiveness of the U.S. legal theory may increase pressure in the future-in situations where it is possible to obtain an initial Security Council authorization to use force- to craft the authorization narrowly. Already aware of the interpretations placed on Resolution 678 by the United States and United Kingdom, in 1994 the Security Council only authorized France to intervene in Rwanda to stop the bloodshed for a set period of time, in that case "a period of two months following the adoption of the present resolution., ${ }^{220}$ Authorization to use force to implement

${ }^{219}$ Sutterlin, supra note 119 , at 9.

${ }^{220}$ See SC Res. 929, para. 4 (June 22, 1994). Interestingly, the limited duration was 
the Dayton Accords was subject to a one-year review, after which it terminated unless renewed. ${ }^{221}$ Other types of limitations are also possible, such as only authorizing the use of force to uphold specific and detailed UN resolutions. ${ }^{222}$

supported by France, as a means of dealing with French domestic concerns about being involved in a prolonged conflict.

${ }^{221}$ See SC Res. 1031, paras. 19, 21 (Dec. 15, 1995).

${ }^{222}$ An example are the fairly specific authorizations to use force in Bosnia to secure the delivery of humanitarian supplies, to enforce a no-fly zone, and to protect specified safe-havens for Bosnian Muslims. See SC Res. 770 (Aug. 13, 1992); SC Res. 816 (Mar. 31, 1993); SC Res. 836 (June 4, 1993); see also Gowlland-Debbas, supra note 98, at 369-70. 
Imposition of such limitations, of course, might discourage the United States from seeking any Security Council authorization, since the U.S. Executive Branch historically has been unwilling to "tie its hands" in advance regarding the length of a deployment, either as a matter of international or U.S. law. On the other hand, the instances when the United States will wish to invade other countries and when the Security Council in principle is willing to authorize such invasion, will likely be very limited. Typically, such instances will involve invasions of countries where the governmental authority is either non-existent or has come to power by ousting a democratic government. In such instances, members of the Security Council may not see any harm in a relatively open-ended authorization, since the fundamental objective right from the start—assuming that a Security Council authorization to use force is possible at all—is to invade and to reconstitute the existing governmental authorities. Those attitudes may help explain the open-ended authorizations for the use of force granted by the Security Council in the 1990's for U.S. invasions in Somalia ${ }^{223}$ and in Haiti. ${ }^{224}$ The harder cases will be where the initial intent is to authorize only a limited use of force, but the United States resists any limitation in the resolution.

The U.S. and U.K. emphasis on the statement by the Secretary-General in 1993 that there

${ }^{223}$ See SC Res. 794 (Dec. 3, 1992).

${ }^{224}$ See SC Res. 940 (July 31, 1994). 
was a "mandate" to use force against Iraq under Resolution 678 also may chill the enthusiasm of Security Council members in agreeing to such informal mandates in the future. If the price of such statements is that states will use them to justify uses of force well beyond those contemplated at the time, it can be expected that the Security Council will be far more careful in issuing them. Exercising greater care in this regard may be good discipline for the Security Council and, again, may enhance its legitimacy, but it will also remove some of the flexibility and discretion the Security Council would otherwise have when engaging in conflict management.

Similarly, the Security Council members in the future may be far less comfortable making vague threats to states about "serious consequences" for "material breaches" of prior resolutions. Such language can be very effective in getting the attention of a recalcitrant state; indeed, the UN drumbeat sounded by the United States in 2002 is the only reason Iraq allowed UN inspectors back into the country after kicking them out in 1998. Yet if such language becomes tantamount to authorizing the use of force, consensus on such language often will not be possible. The conundrum, of course, is that such threats are most effective when it appears that little if anything further is needed from the Security Council for force to be unleashed - the very imminency that most members of the Security Council do not actually intend. Rather, they want to impose a threat that will be heeded, without actually authorizing the use of force. To the extent that the Security Council becomes incapable of enacting forceful resolutions that threaten sanctions, the Security Council will be weakened. ${ }^{225}$

${ }^{225}$ It remains too soon to assess the fall-out from the invasion of Iraq, but U.S. efforts at the Security Council to obtain a strong resolution condemning North Korean intransigence faltered in mid-April 2003, see James Brooke, North Korea Shifts Stance on Discussing Nuclear Arms, N.Y. Times, Apr. 13, 2003, at A4, perhaps due to uncertainty by some of the members (China, Russia) as to where such condemnation may lead. At the same time, the aggressiveness of the United States in dealing with intransigent regimes may have prompted North Korea to be 
IV. Does International Law Really Matter to the Use of Force?

more accommodating in its negotiations. See, e.g., Mike Allen, Bush: Iraq War Drove N. Korea to Concede, WASH. Post, Apr. 14, 2003, at A11. 
Skeptics about the role of international law in international relations (typically associated with the school of "international realism" in international relations theory ${ }^{226}$ ) would likely point to the U.S. invasion of Iraq as yet another example of major power politics operating under a facade of law. For the Skeptic, international law and international institutions (in the form of the Security

226 The school of "realism" is hardly monolithic, and ranges from classical realists, such as George Kennan and Henry Morgenthau, to "neo-realists," such as Kenneth Waltz. See George Kennan, AmericAn Diplomacy, 1900-1950 (3d ed. 1984); Hans J. Morgenthau, Politics Among NAtions (4th ed. 1966); Kenneth N. WALtz, TheOrY OF InTERnAtional POLITICS (1979). Adherents to the school, however, generally agree that states act so as to maximize their power, security and wealth vis-à-vis other states. To the extent that states are observed as "abiding" by international law, they are only doing so when it serves their interests (i.e., they would have acted the same whether the rule existed or not). Further, states readily deviate from those rules if the states' interests so dictate, unless a more powerful state prevents them from doing so. 
Council) had nothing much to do with the invasion of Iraq; the Bush administration decided in the summer of 2002 that it wanted to invade Iraq, and it proceeded to do it. On this reading, the U.S. legal theory was simply an attempt at camouflaging the pursuit by a "hegemonic" power of its national interests; a "fig leaf" that had no normative effect on the United States.

While it is certainly the case that the United States was pursuing its interests when it invaded Iraq, the Skeptic's critique would appear to explain inadequately the behavior of the United States with respect to this incident, for it would ignore myriad actors involved in shaping the U.S. decisionmaking process, and the role that international law and institutions played in mediating among those actors. As discussed below, international law and international institutions appear to have played a rather considerable role in framing the debate on whether force should be used against Iraq and in providing a forum for that debate. Moreover, while the United States ultimately proceeded with the invasion on the basis of an unpersuasive legal theory, such U.S. non-compliance in this case with international law should not be read as either discrediting international norms on the use of force generally, nor as undermining the relevance of the Security Council as an institution for promoting international peace and security.

\section{A. International Law as a Mediating Factor in the Invasion of Iraq}

If one were to approach the issue of a U.S. invasion of Iraq during the summer of 2002 from Skeptic's perspective, one would have predicted that the Bush administration would decide whether U.S. interests were advanced by invading Iraq and, having decided that they were, would have simply proceeded to plan and execute the invasion. Instead, the Bush administration — which came 
to office reportedly with considerable distrust and even disdain for international law and institutions - took its case to the United Nations. Rather than simply unleash a unilateral use of force, the Bush Administration engaged in extensive diplomacy both in New York and in foreign capitals in an effort to obtain Security Council authorization, at considerable risk to U.S. standing and prestige if diplomacy failed. As demonstrated in the prior section, the history of U.S. actions against Iraq from 1990 to the present entailed repeated reference to the UN Charter, to prior Security Council resolutions, to Iraqi compliance with those resolutions, and to the need for further authorization to respond to Iraqi non-compliance. In short, the rudimentary attitudes, assumptions, prejudices, and perceptions brought to the table by the United States, and the response by other states to those actions, were embedded in a matrix of norms provided by international law. ${ }^{227}$ Those norms included a recognition of the general prohibition on the use of force in international law, ${ }^{228}$ of an exception to that general prohibition for uses of force authorized by the Security Council in response to a threat to the peace, ${ }^{229}$ of the collective legitimacy obtained through securing Security Council authorization, of the "bindingness" of Security Council resolutions on all UN member states, ${ }^{230}$ and of the need to conduct warfare in accordance with principles of international

${ }^{227}$ See Martti Koskenniemi, The Place of Law in Collective Security, 17 Mich. J. InT'L L. 455, 468 (1996) ("Arguing that normative factors are either irrelevant or only marginally relevant to Security Council action undermines the degree to which any social action, including international activity, makes constant reference to normative codes, rules, or principles."). For a discussion of such a "justificatory discourse" at the Security Council with respect to the intervention in Kosovo, see Ian Johnstone, Security Council Deliberations: The Power of the Better Argument, 14 EUR. J. INT'L L. (forthcoming 2003).

${ }^{228}$ See UN CHARTER, art. 2(4).

${ }^{229}$ See id., ch. VII.

${ }^{230}$ See id., art. 25. 
humanitarian law, including the 1949 Geneva Conventions and the 1907 Hague Regulations. ${ }^{231}$

${ }^{231}$ See Convention for the Amelioration of the Condition of the Wounded and Sick in Armed Forces in the Field, Aug. 12, 1949, 6 U.S.T. 3114, 75 U.N.T.S. 31 (1949 Geneva Convention I); Convention for the Amelioration of the Condition of Wounded, Sick and Shipwrecked Members of Armed Forces at Sea, Aug. 12, 1949, 6 U.S.T. 3217, 75 U.N.T.S. 85 (1949 Geneva Convention II); Convention Relative to the Treatment of Prisoners of War, Aug. 
12, 1949, 6 U.S.T. 3316, 75 U.N.T.S. 135 (1949 Geneva Convention III); Convention Relative to the Protection of Civilian Persons in Time of War, Aug. 12, 1949, 6 U.S.T. 3526, 75 U.N.T.S. 287 (1949 Geneva Convention IV); Hague Regulations, supra note 82.

The United States regarded such conventions and rules as applicable to conduct of the United States and Iraq during the invasion. See U.S. Dep't of Defense Transcript, Briefing on Geneva Convention, EPW's and War Crimes (Apr. 7, 2003), at $<$ http://www.defenselink.mil/news/Apr2003/t04072003_t407genv.html>; U.S. Dep't of Defense Transcript, Teleconference Briefing from Umm Qasr, Iraq on Enemy Prisoner of War Issues (Apr. 9, 2003), at <http://www.dod.mil/transcripts/2003/tr20030409-0083.html>;U.S. Dep't of Defense Transcript, Briefing via Satellite-Teleconference on Medical Care Being Provided to Enemy POWs (Apr. 11, 2003), at <http://www.dod.mil/transcripts/2003/tr20030411-0089.html>. 
Indeed, even after it became apparent that a new Security Council authorization would not be forthcoming in March 2003, the central feature of the U.S. legal theory was the failure of a member state to abide by Security Council resolutions. Regardless of whether one agrees with the U.S. legal theory, or with the policy decision to invade Iraq, the heart of the asserted U.S. legal justification was enforcement of measures previously ordered by the Security Council, not the transgression of extant Security Council decisions. By seeking to place the invasion within the scope of the basic UN Charter paradigm, the United States paid homage to that paradigm. ${ }^{232}$

${ }^{232}$ See Military and Paramilitary Activities in and against Nicaragua (Nicar. v. U.S.), 1986 ICJ REP. 14, 98, para. 186 ("If a State acts in a way prima facie incompatible with a recognised rule, but defends its conduct by appealing to exceptions or justifications contained within the rule itself, then whether or not the State's conduct is in fact justifiable on that basis, the significance of that attitude is to confirm rather than to weaken the rule."). 
Why, then, did the United States seek to justify its action (and did the international community judge that action) in accordance with a normative code provided by international law? International lawyers and international relations "regime" theorists have long recognized that states are motivated by many factors other than a simple assessment of short-term political gain from a particular course of action. Rather, they are also motivated by factors internal to the state (factors rooted in the state's national law, history, tradition and values, including the social conditioning of persons in government to adhere to law or to at least avoid non-compliance with the law), and factors external to the state (factors such as the desire of a state for orderly relations, to maintain a reputation of principled behavior, and to avoid adverse communal responses to its actions). ${ }^{233}$ These factors include the benefits derived from the "collective legitimization" obtained when the Security Council authorizes a use of force. ${ }^{234}$ Many of those factors appear to have been at issue in the U.S. decision to go to war.

First, within the U.S. executive branch, there were reportedly disagreements about whether and why the U.S. should take military action against Iraq. The standard account is that several conservative "hawks," consisting of individuals such as Vice President Cheney, Secretary of Defense Rumsfeld, and Deputy Secretary of Defense Wolfowitz favored action against Iraq because Iraq was a rogue nation that threatened U.S. interests and whose leader should have been ousted in

233 See, e.g., Louis Henkin, How Nations Behave 49-68 (2d ed. 1979); ABRAM Chayes \& Antonia Handler Chayes, The New Sovereignty: Compliance With InTERNATIONAL REgUlatory AgreEMENTS 1-17 (1995); InTERNATIONAL REgimes (Stephen D. Krasner ed., 1983).

${ }^{234}$ See generally Inis. L. Claude, Collective Legitimization as a Political Function of the United Nations, 20 INT'L ORG. 367 (1966). 
1991 as part of Operation Desert Storm. ${ }^{235}$ Others, such as Secretary of State Colin Powell and the Joint Chiefs of Staff had doubts about the need to invade Iraq and instead initially favored a strategy of containment; when they later came to accept that intervention was likely, they sought to sought to secure as broad support internationally as possible, with particular attention to securing the support of a major European ally, the United Kingdom. Ultimately, the reason for resort to war that could be agreed upon among the factions within the Executive Branch was Iraq's possession of WMD. ${ }^{236}$ Since many other states also possess WMD, this policy justification inexorably carried with it reference to a normative legal framework, specifically Iraq's failure abide by its international disarmament obligations.

${ }^{235}$ See, e.g., U.S. Dep't of Defense News Transcript, Deputy Secretary Wolfowitz Interview with Sam Tannenhaus, Vanity Fair (May 9, 2003), at <http://www.defenselink.mil >. In the interview, Wolfowitz asserts that within the U.S. government there were four "fundamental concerns" with respect to Iraq: (1) Iraq's possession of WMD; (2) Iraq's support for terrorism; (3) the possibility of WMD being supplied by Iraq to terrorists; and (4) Iraq's treatment of its own people. With respect to the fourth concern, Wolfowitz stated that "it's not a reason to put American kids' lives at risk." Wolfowitz also noted that he, personally, thought ouster of Saddam Hussein would assist in achieving a broader peace in the Middle East.

${ }^{236} I d$. ("The truth is that for reasons that have a lot to do with the U.S. government bureaucracy we settled on the one issue that everyone could agree on which was weapons of 
mass destruction as the core reason ...."). 
In other words, while disputes apparently existed among and even within U.S. government agencies as to how the U.S. government should justify its action, the common denominator that emerged was a legal justification grounded in prior Security Council resolutions. Such a justification reflected a rejection of persons who may have favored a U.S. invasion based solely on grounds that U.S. military power made an invasion possible, without any reference to a normative framework. Such a justification also reflected a rejection of persons who may have favored a U.S. invasion based solely on humanitarian grounds, as a means of protecting the human rights of the Iraqi people. Further, such a justification reflected a rejection (for now at least) of those who may have favored a U.S. invasion based on an expansive definition of self-defense, using the much-discussed doctrine of "preemptive self-defense." Indeed, the U.S. decision not to invoke that doctrine should be seen as an unwillingness on the part of some persons in the Executive Branch to adopt a normative theory that could severely impair the UN Charter use of force paradigm. Thus, the debate within the U.S. executive branch reflects an understanding of and concern with the potential precedent that may be set by the U.S. action, and hence an understanding of the power of precedent (a component of legal reasoning) in global normative discourse.

Second, while the U.S. Executive Branch was the central actor in the decision to invade Iraq, its decision-making was socially constrained by other factors, such as U.S. public opinion and, concomitantly, Congressional opinion. ${ }^{237}$ Although not stated expressly in so many terms, that

${ }^{237}$ See, e.g., Helen Dewar \& Mike Allen, Senators Wary About Action Against Iraq, WASH. Post, Sept. 4, 2002, at A1 (reporting that "[e]ven some of the president's strongest supporters suggested that, while they might support military action, they cannot do so based on 
public opinion appears to have been concerned with the normative code of international law. ${ }^{238}$ As late as February 2003, one public opinion poll showed that 59 percent of Americans said they believed the president should give the United Nations more time to conduct weapons inspections in Iraq, 63 percent said the president should not resort to war without the support of allies, and 56 percent said the president should wait for Security Council authorization. ${ }^{239}$ As a result, many congressional members framed their support in terms of cooperation with allies and specific authorization from the United Nations. ${ }^{240}$ Such attitudes help explain why President Bush in September 2002 began developing the support of foreign leaders ${ }^{241}$ and made a widely-reported

what they - and the American public - have been told so far."); Alison Mitchell \& David E. Sanger, Bush to Put Case for Action in Iraq to Key Lawmakers, N.Y. TIMES, Sept. 4, 2002, at A1 (reporting that "senators raised concerns about alienating allies needed for the broader campaign against terrorism, as well as about divisions within the administration itself.").

${ }^{238}$ On why national democratic systems would favor compliance with international law, see Andrew Hurrell, International Society and the Study of Regimes: A Reflective Approach, in REGIME THEORY AND INTERNATIONAL RELATIONS 49 (Volker Rittberger ed., 1993). For a discussion of this phenomenon in the context of U.S. congressional and public support, and foreign support, for armed intervention in Haiti in 1994, see DAVID MALONE, DECISION-MAKING IN THE UN SECURITy COUNCIL: THE CASE OF HAITI, 1990-1997, at ix \& ch. 6 (1998).

${ }^{239}$ See Patrick E. Tyler \& Janet Elder, Poll Finds Most in U.S. Support Delaying a War, N.Y. TIMES, Feb. 14, 2003, at A1 (reporting on a New York Times/CBS news poll based on random interviews with adults throughout the United States).

${ }^{240}$ See, e.g., Bradley Graham, Cheney, Tenet Brief Leaders of Hill on Iraq, WASH. Post, Sept. 6, 2002, at A1 (reporting that Senate minority leader Thomas A. Daschle "indicated yesterday that his own backing and that of other senators would hinge in part on Bush's success in gathering international support. He suggested that Bush try to get the kind of U.N. Security Council resolution - authorizing the use of 'all necessary means' to evict Iraqi forces from Kuwait— that Bush's father obtained before the 1991 Persian Gulf War.”).

${ }^{241}$ See, e.g., David E. Sanger, Blair, Meeting with Bush, Fully Endorses U.S. Plans for Ending Iraqi Threat, N.Y. TIMES, Sept. 8, 2002, at 23; Julia Preston \& Todd S. Purdum, U.S. Moves to Persuade Security Council to Confront Iraq on Arms Inspections, N.Y. TIMES, Sept. 14, 2002, at A6; see also Mike Allen, War Cabinet Argues for Iraq Attack, WASH. Post, Sept. 9, 2002, at A1 (quoting Vice President Cheney that "[w]e're trying very hard not to be 
speech to the UN General Assembly committing the United States to "work with the U.N. Security Council to meet our common challenge", albeit at the same time warning the United Nations that a failure to act would call into question its relevance. ${ }^{242}$ That commitment to work with the United Nations, in turn, led to the extensive efforts recounted in the last section to obtain Resolution 1441, and to then convince the global community that Iraq had failed to meet the standards set by Resolution 1441. With an eye to both U.S. public opinion and a desire to influence foreign governments, President Bush in the fall of 2002 also sought and received authorization from the U.S. Congress to use military force against Iraq framed in part on the continuing vitality of Resolution 678, on Iraq's development of WMD in violation of Resolution 687, and on what was "necessary and appropriate" to "enforce all relevant United Nations Security Council resolutions regarding Iraq. ${ }^{243}$ Moreover, when invoking such authorization, the president was required to determine that

unilateralist" and "[w]e're working to build support with the American people, with the Congress, as many have suggested we should. And we're also, as many have suggested we should, going to the United Nations.").

${ }^{242}$ Address to the United Nations General Assembly in New York City, supra note 160, at 1532 .

${ }^{243}$ Authorization for Use of Military Force Against Iraq Resolution of 2002, supra note 3 , at pmbl. \& §3(a)(2). The resolution also references Iraq's repression of its own people in violation of Resolution 688 (Apr. 5, 1991) and Iraq's threats against its neighbors in violation of Resolution 949 (Oct. 15, 1994).

In the course of Congress' consideration of this authorization, a conservative member of the Democratic caucus, Congressman John Spratt of South Carolina, offered an amendment that would have only authorized force if the Security Council adopted a new resolution authorizing the use of force. See H. Amdt. 609 (A002), 107th Cong. (2002). If the Security Council failed to adopt such a new resolution, the Spratt amendment would have allowed the president to return to Congress for expedited consideration of whether Congress should authorize a use of force in the absence of a new Security Council resolution. The Spratt amendment failed, but garnered more than 150 votes, see 148 CONG. REC. 7769 (daily ed. Oct. 10, 2002), and thus likely signaled to the president a strong Congressional interest in obtaining a new Security Council resolution. 
further diplomatic or other peaceful means were not available. ${ }^{244}$ Only over time, after trying to obtain UN support without success and after a U.S. government campaign to establish that Iraq was already in non-compliance with its international obligations, did U.S. public opinion polls shift in support of the resort to war. ${ }^{245}$

${ }^{244}$ Authorization for Use of Military Force Against Iraq Resolution of 2002, supra note 3 , at $\S 3(b)(1)$.

${ }^{245}$ See Adam Nagourney \& Janet Elder, More Americans Now Faulting U.N. on Iraq, Poll Finds, N.Y. TIMES, Mar. 11, 2003, at A1. 
As noted above, U.S. public and congressional opinion turned in part on the desire for the support of foreign governments; consequently, that support served as an external factor that socially constrained U.S. decision-making. ${ }^{240}$ From the start of the process until the invasion itself, it remained extremely important to the U.S. government that it have "allies" and ultimately that there be a "coalition" of states supporting the invasion. Yet for many states, such as France, Germany, and the United Kingdom, the need to explain to their legislatures and to their peoples that the action to be taken conforms with international law was demonstrable. ${ }^{241}$ With respect to the invasion of Iraq, the U.S. government found that it needed and heavily relied upon the United Kingdom as an ally, a credible European state capable of joining the United States in deploying meaningful military power. The United Kingdom, however, faced the same kind of internal factors (satisfying Parliament and public opinion) faced by the U.S. government. For U.K. Prime Minister Tony Blair, obtaining Security Council authorization was extremely important, to the point that his government was considered possibly at risk of falling in March 2003 when it became clear that express Security Council authorization was not forthcoming. ${ }^{242}$ Ultimately, it was critical for the Blair government

${ }^{240}$ The phenomenon of a state's preferences being socially constructed by other states through the enunciation of norms is the central insight of the "constructivist" approach to international relations theory and stands in sharp contrast to the traditional "realist" approach. See generally John Gerard Ruggie, What Makes the World Hang Together? Neo-utilitarianism and the Social Constructivist Challenge, 52 InT'L ORG. 855 (1998); JOHN GERARD RUGGIE, CONSTRUCTING THE WORLD POLITY: ESSAYS ON INTERNATIONAL INSTITUTIONALIZATION (1998); Alexander Wendt, Social Theory of International Politics (1999).

${ }^{241}$ See, e.g., Krisch, supra note 19, at 97-98.

${ }^{242}$ See, e.g., Glenn Frankel, Parliament Backs Blair on Action Against Baghdad, WASH. Post, Mar. 19, 2003, at A17 (reporting on a revolt in Blair's Labor Party that ultimately was defeated); Karen DeYoung \& Colum Lynch, Britain Races to Rework Resolution, WASH. Post, Mar. 11, 2003, at A1 (reporting that "the [Bush] administration has gone along with Britain's diplomatic efforts out of recognition of the opposition Blair faces at home"). 
that the legal justification at a minimum be based on a construction of existing Security Council resolutions, rather than adoption of a more aggressive legal theory, such as the theory of preemptive self-defense.

In addition to the public relations value in having foreign support, the U.S. government cared about the views of foreign states due to an interest in sharing the financial burden of the intervention and post-intervention costs, and due to practical needs in deploying U.S. military force. U.S. military power is such that it can undertake actions using solely its own military forces, but the deployment of those forces typically requires access to foreign airfields, ports, and railways and the prepositioning of equipment and supplied abroad. In conducting the invasion of Iraq, the United States relied on personnel and pre-positioned equipment in various states, including Bahrain, Djibouti, Jordan, Kuwait, Oman, Qatar, Saudi Arabia, the United Arab Emirates, and the United Kingdom's Diego Garcia. ${ }^{243}$ Other states were instrumental in allowing U.S. transit of personnel, equipment, and vessels. ${ }^{244}$ While a survey of the government and public attitudes in all those states is beyond the scope of this study, at least some of those states' views appear to have been strongly influenced by whether the invasion could be justified within an international normative framework. Perhaps the most striking example of this phenomenon was Turkey's refusal to allow the deployment of U.S.

${ }^{243}$ See Vernon Loeb \& Bradley Graham, Rapid Buildup in Gulf on Horizon, WASH. Post, Dec. 20, 2002, at A45.

${ }^{244}$ See, e.g., Brady Kiesling, Athens in Wartime, N.Y. REV. BooKs, May 15, 2003, at 16 ("Thanks to the Greek government's blanket flight clearances and concessions on security issues, the crucial Mediterranean port and airfield of Souda Bay in Crete quietly handled thousands of US military flights and hundreds of ships en route to the Gulf.") 
ground forces through Turkey. ${ }^{245}$ Turkey's reasons for refusing were complex, but the strong divisions in the international community and the lack of a clear authorization from the Security Council appear to have been a major factor in Turkey's deliberations. ${ }^{246}$ That refusal, in turn,

${ }^{245}$ See Philip P. Pan, Turkey Rejects U.S. Use of Bases, WASH. Post, Mar. 2, 2003, at A1.

${ }^{246}$ See, e.g., Michael R. Gordon, Threats and Responses: The Allies, N.Y. TIMES, Jan. 9, 2003, at A1 (reporting that "some Turkish officials are insisting that the government cannot make a decision without a second United Nations resolution approving military action"); Karl Vick, Turkey and U.S. Closer on Troops, WASH. PosT, Feb. 1, 2003, at A16 (reporting that "Turkey's influential National Security Council called on parliament today to allow the United States to station troops there for a possible war against Iraq, but made its recommendation contingent on "international legitimacy", and that "Turkish leaders have interpreted that phrase 
impaired the ability of the United States to confront Iraqi forces on two fronts and may explain some of the difficulties experienced by U.S. forces in southern Iraq in the initial days of the war. ${ }^{247}$ More generally, U.S. officials reportedly stated that the original U.S. plan for invading Iraq, which included an extensive bombing campaign prior to introducing ground forces, was altered due to a belief that the lack of global support made a lengthy air campaign, with the inevitable collateral civilian casualties, untenable. ${ }^{248}$

to mean that there must be a U.N. resolution authorizing war"); Philip P. Pan, Turkish Party Leader Hints at Conditions for U.S. Deployment, WASH. Post, Mar. 10, 2003, at A12 (reporting that Turkey's ruling party leader would schedule a parliamentary vote after the UN Security Council reached a decision on the proposed UK/US/Spain resolution authorizing a use of force).

${ }^{247}$ Turkish refusal to allow ground forces to deploy from Turkey prevented the mechanized U.S. Fourth Infantry division from invading Iraq. Instead, the United States had to conduct one of the largest paratroop drops since the Second World War to establish a modest northern front. See Michael R. Gordon, 1,000 U.S. Paratroopers Open Northern Front, N.Y. TIMES, Mar. 27, 2003, at A1 (reporting that “Turkey's decision to deny access to American ground forces has made it difficult for the United States to open a northern front, a factor that has enabled Mr. Hussein to send most of his zealous paramilitary forces south.").

${ }^{248}$ See, e.g., Steven R. Weisman, Politics Shapes the Battlefield in Iraq, N.Y. TIMES, 
Mar. 30, 2003, §4 at 3. By contrast, the UN-authorized use of force against Iraq in 1991 entailed a six-week bombing campaign prior to the introduction of ground forces. 
Even after the United States proceeded to invade Iraq without express Security Council authorization, the United States remained confronted with the normative legal structures that defined the relationship between Iraq and both the United States and global community more generally. With respect to the relationship between Iraq and the United States, the United States sought to assess Iraq's conduct during the conflict by reference to the laws of war, as well as U.S. treatment of Iraqi prisoners of war. ${ }^{249}$ With respect to the broader relationship of the global community to Iraq, comprehensive economic sanctions had been ordered by the Security Council in 1990 that all states regarded as obligatory in their relations with Iraq and that could not be altered by U.S. fiat. That sanctions regime included a process, beginning in 1996, whereby proceeds from Iraqi oil exports were deposited in a UN-administered account and used by Iraq to pay for imports of food and medicine, which were then distributed by the Iraqi government in Iraq. ${ }^{250}$ During the course of the war, once the government of Iraq became incapable of serving this function, United States had no choice but to return to the Security Council for a resolution transferring the distribution function to

${ }^{249}$ See U.S. Dep't of Defense Transcript, Briefing on Geneva Convention, EPW's and War Crimes (Apr. 7, 2003), at $<$ http://www.defenselink.mil/news/Apr2003/t04072003_t407genv.html>; U.S. Dep't of Defense Transcript, Teleconference Briefing from Umm Qasr, Iraq on Enemy Prisoner of War Issues (Apr. 9, 2003), at <http://www.dod.mil/transcripts/2003/tr20030409-0083.html>;U.S. Dep't of Defense Transcript, Briefing via Satellite-Teleconference on Medical Care Being Provided to Enemy POWs (Apr. 11, 2003), at <http://www.dod.mil/transcripts/2003/tr200304110089.html>; see also Diana Jean Schemo, Iraq Violates Rules of War, U.S. Complains, N.Y. TIMES, Mar. 24, 2003, at B6; Steve Fainaru \& Dan Eggen, Prisoner Images Are Tough Issue for Iraq and U.S., WAsh. Post, Mar. 25, 2003, at A24; Neil A. Lewis, U.S. Is Preparing to Try Iraqis for Crimes Against Humanity and Mistreating Prisoners, N.Y. TIMES, Mar. 29, 2003, at B14.

${ }^{250}$ The program, which was subject to UN monitoring, fed more than half of Iraq's population. For the initial Security Council resolution authorizing the oil-for-food program, see SC Res. 986 (Apr. 14, 1995); see also <http://www.un.org/Depts/oip/>. 
the United Nations. ${ }^{251}$

${ }^{251}$ SC Res. 1472 (Mar. 28, 2003). While the United States was successful in obtaining the resolution, the associated Security Council debate was contentious, with several states expressing a concern that the resolution not be viewed as condoning the war or U.S. occupation of Iraq. See UN Doc. S/PV.4732 at 3 (Mar. 28, 2003) (Syria, Russia); see also Colum Lynch \& Kenneth Bredemeier, U.S. Hits Snag in U.N. on Aid for Iraq, WASH. Post, Mar. 26, 2003, at A29; Felicity Barringer, Security Council Votes to Revive Oil-for-Food Program in Iraq, N.Y. TIMES, Mar. 29, 2003, at B7. Such statements in the course of adoption of this resolution, as well statements made during the adoption of subsequent resolutions by the Security Council

concerning the U.S. role in Iraq, strongly indicate that the members of the Security Council were not authorizing the invasion of Iraq ex post facto but, rather, were coping with the reality of the invasion and the need to address the well-being and reconstruction of Iraq. 
Moreover, once the armed conflict ended, the United States wished to lift the economic sanctions entirely as a means of placing Iraq back on the road to reconstruction. The sanctions posed real obstacles, not just for global imports to and exports from Iraq, but also for obtaining loans from international financial institutions ${ }^{252}$ or from states ${ }^{253}$ for Iraqi reconstruction. Consequently, again the United States had to turn to the Security Council for a resolution lifting the sanctions. Before doing so, the United States and the United Kingdom presented a letter to the Security Council in essence acknowledging their responsibilities as occupying forces under international law, pledging to ensure "that Iraq's oil is protected and used for the benefit of the Iraqi people" and "to transfer responsibility for administration to representative Iraqi authorities as early as possible."254 After two weeks of negotiations, during which some ninety changes were reportedly made to the original U.S./UK/Spain draft, ${ }^{255}$ the Security Council on May 22 adopted Resolution 1483 lifting the sanctions (except for arms). ${ }^{256}$ At the same time, the resolution contained various provisions that defined Iraq's relationship with the global community, such reaffirming Iraq's sovereignty and territorial integrity, recognizing the right of the Iraqi people to establish a representative government

${ }^{252}$ See Elizabeth Becker, U.S. and Allies Seek U.N. Resolution to Promote Iraq Aid, N.Y. Times, Apr. 13, 2003, at B7.

${ }^{253}$ See Elizabeth Becker, Help is Tied to Approval By the U.N., N.Y. TIMES, Apr. 12, 2003, at B8; see also Colum Lynch, Potential Iraqi Donors Seek Greater Accountability from U.S. on Oil Plans, WASH. Post, June 26, 2003, at A16.

${ }^{254}$ Letter Dated 8 May 2003 from the Permanent Representatives of the United Kingdom of Great Britain and Northern Ireland and the United States of America addressed to the President of the Security Council, UN Doc. S/2003/538 (May 8, 2003).

${ }^{255}$ See Colum Lynch, France, Russia Back Lifting of Iraq Sanctions, WASH. Post, May 22, 2003, at A1.

${ }^{256}$ See SC Res. 1483, para. 10 (May 22, 2003). The vote was 14-0, with Syria absent. 
based on the rule of law, and empowering a special UN representative to coordinate humanitarian and refugee activities. ${ }^{257}$

${ }^{257} I d$., pmbl., paras. 8-9. The Secretary-General named as his special representative Sergio Vieira de Mello, the UN High Commissioner for Human Rights. 
Similarly, the resolution helped define the U.S./U.K. role in Iraq, recognizing those states as "occupying powers under unified command" who must comply with their obligations under international law, ${ }^{258}$ while at the same time addressing that role (and the role of others who are not occupying forces) in a manner that deviates from international humanitarian law. ${ }^{259}$ First, the resolution crystalized an expectation that the occupying powers were an "authority" with the responsibility to:

promote the welfare of the Iraqi people through the effective administration of the territory, including in particular working towards the restoration of conditions of security and stability and the creation of conditions in which the Iraqi people can freely determine their own

${ }^{258}$ Id., pmbl., paras. 4-5.

259 The use of Security Council resolutions, rather than international humanitarian law, as a central device for determining the rights and duties of an occupying power may be seen in several recent military deployments, such as in Afghanistan and Kosovo. 
political future. ${ }^{260}$

${ }^{260}$ Id., para. 4. 
By contrast, international humanitarian law disfavors changes in local laws and institutions by an occupying power. ${ }^{261}$ Second, the concern of several states as to developmental aid to Iraq was addressed in provisions recognizing the creation of a Development Fund to be held by the Central Bank of Iraq; while the funds were to be disbursed at the direction of the occupying powers, the resolution makes clear the purposes to which the funds may be put (e.g., economic reconstruction and repair of infrastructure) and that the fund will be audited by independent public accountants appointed by the UN Secretary-General and the directors of certain multilateral financial institutions. ${ }^{262}$ Third, the concern as to U.S. treatment of Iraqi oil resources was addressed in the preamble by noting "the right of the Iraqi people freely to ... control their own natural resources," and in a provision stating that "all export sales of petroleum, petroleum products, and natural gas from Iraq . . shall be made consistent with prevailing international market best practices" (also to be independently audited), with the proceeds to be placed in the Development Fund. ${ }^{263}$ Unencumbered funds already held in the UN escrow account under the "oil-for-food" program were also transferred to the Development Fund, with the phase-out of the program over a period of six months. ${ }^{264}$ At the same time, the United States needed the Security Council to help ensure that Iraq's debts would not impede the restarting of Iraqi oil exports and use of oil revenues for Iraqi reconstruction. Consequently, the resolution requires all states to accord immunity - until December 2007 - to Iraqi oil and oil revenues, and to the Development Fund, from any attachments or

${ }^{261}$ Hague Regulations, supra note 82, art. 43. 1949; 1949 Geneva Convention IV, supra note 231 , art. 47 .
${ }^{262} I d$., paras. 12-14.
${ }^{263}$ Id., pmbl. \& para. 20. 
executions as a means of allowing Iraq time to establish a new government and to restructure its debt. ${ }^{265}$ Although some states initially asserted that the lifting of sanctions should only occur in the context of a decision by UN weapons inspectors that Iraq no longer had WMD, the United States stated that it had assumed the responsibility for such inspections, ${ }^{266}$ and the resolution left the issue unaddressed.

${ }^{264} I d$., paras. 16-17.

${ }^{265} I d$., para. 22.

${ }^{266}$ See, e.g., Felicity Barringer, U.N. Reaction to Resolution Seems Positive but Reserved, N.Y. Times, May 10, 2003, at A13. 
It appears likely that the Security Council will remain significant to U.S. actions in Iraq in the months (and perhaps years) to come. While Resolution 1483 has no fixed termination date, it states that the Security Council will "review the implementation of this resolution within twelve months of adoption . . . to consider further steps that might be necessary." ${ }^{267}$ Moreover, other Security Council authorizations were soon seen to be necessary to achieve U.S. goals in Iraq. After the United States encountered considerable Iraqi resistance to the presence of U.S. forces in Iraq, the United States became eager for other countries to send forces to Iraq, ${ }^{268}$ but found that many of those countries expected a further Security Council authorization for the deployment of peacekeeping forces. ${ }^{269}$

${ }^{267}$ Id., para. 25.

${ }^{268}$ See, e.g., William C. Mann, Global Force Urged for Iraq, WASH. Post, June 30, 2003, at A9 (reporting on Congressional views that U.S. casualties in Iraq required seeking deployments and other assistance from abroad).

269 See, e.g. Christopher Marquis, U.S. May Be Forced to Go Back to U.N. for Iraq Mandate, N.Y. TIMES, July 19, 2003, at A1; John Lancaster, India Rejects Request by U.S. for Iraq Force, Wash. Post, July 15, 2003, at A10; Keith B. Richburg, NATO Role in Iraq Faces Snags, WASH. Post, July 12, 2003, at A13; Karen DeYoung, 1,500 Spanish Troops to Aid Iraq 
Recovery, WAsh. Post, May 8, 2003, at A21; Bradley Graham, U.S. to Help Finance Polish Peacekeepers, WASH. Post, May 6, 2003, at A13; see also Elaine Sciolino, France Declines U.S. Call for Iraq Force, N.Y. TIMES, July 16, 2003, at A9; Germany Refuses to Join Iraq Peacekeepers, N.Y. TIMES, May 8, 2003, at A13. 
In sum, even though the United States proceeded to invade Iraq without a persuasive legal justification, there should be little doubt that international norms and institutions served as a key focal point for discourse between the United States and the global community. As discussed in Part II, from 1990 forward the Security Council was at the heart of global efforts to deal with Iraq: States repeatedly interacted in consultations and meetings at the Security Council, and the resolutions passed by the Security Council framed global community expectations regarding what Iraq should do and how states should deal with Iraq. Ultimately, the United States decided to invade Iraq using a legal justification that was not persuasive, yet even that justification was ostensibly predicated on enforcement of norms generated by the Security Council. The Security Council remained relevant in the aftermath of the invasion as a mechanism for establishing global community expectations about the U.S./U.K. role in Iraq, about the relationship of states and international institutions to the reconstruction of Iraq, and about the future reconstitution of Iraq on the basis of democracy and the rule of law. It may be true that these post-invasion decisions were largely in accord with U.S. policy objectives, but that fact does not undercut the importance and relevance of the Security Council in sorting out the appropriate basis upon which members states that opposed the invasion should proceed.

\section{B. International Law and the Security Council as a Means of Preventing the Use of Force}

One might accept that international law and international institutions played an important role in the events leading up to the U.S. invasion of Iraq, but still be of the view that, ultimately, the fact of the invasion - in the face of no persuasive legal justification-discredits the idea that 
international rules on the use of force constrain state behavior and the idea that the Security Council plays an important role in coordinating collective security. ${ }^{270}$ One effort to determine the attitudes of persons worldwide in the aftermath of the invasion indicated that one of the biggest casualties of the war was the credibility of the United Nations, for persons in states that both opposed and supported the war. ${ }^{271}$ Indeed, notwithstanding the discussion above, one might still argue that President Bush decided in summer of 2002 to invade Iraq and, while he played a game of discussions at the United Nations and with allies about international law, at the end of the day the United States went ahead and invaded when those discussions did not proceed to the U.S. liking. Certainly the rhetoric of President Bush would support such a claim: in the course of taking the U.S. case to the United Nations, President Bush repeatedly stated that the United States wanted U.N. support but, if such support was not forthcoming, the United States would still take action to enforce Iraq's WMD obligations. ${ }^{272}$

${ }^{270}$ See, e.g., Michael J. Glennon, Why the Security Council Failed, FOREIGN AFF., May/June 2003, 1, 16 ("With the dramatic rupture of the UN Security Council, it became clear that the grand attempt to subject the use of force to the rule of law had failed."); Anthony Clark Arend, International Law and the Preemptive Use of Military Force, WASH. Q., Spring 2003, 89 at 101 ("For all practical purposes, the UN Charter framework is dead."). Arguably, the U.S. action was even more harmful to the international rule of law than NATO's bombing campaign against Serbia in 1999 to protect Kosovar Albanians, for in that case there was no highly visible effort to get the Security Council on board which then failed, nor an effort to invade and occupy Serbia, and depose its government.

${ }^{271}$ See Pew Research Center for the People and the Press, Views of a Changing World, at 1-2 (June 3, 2003), at <http://people-press.org/reports/display.php3?ReportID=185> (survey conducted by interviewing 500 to 1,000 adults in each of twenty states, as well as the area administered by the Palestinian Authority).

${ }^{272}$ See, e.g., Address to the United Nations General Assembly in New York City, supra note 160, at 1532 ("We will work with the U.N. Security Council for the necessary resolutions. But the purposes of the United States should not be doubted. The Security Council resolutions will be enforced, the just demands of peace and security will be met, or action will be 
unavoidable."); The President's News Conference, supra note 190, at 302 ('I'm confident the American people understand that when it comes to our security, if we need to act, we will act, and we really don't need United Nations approval to do so."); Address to the Nation on Iraq, 39 WeEKLy COMP. PRES. Doc. 338, 339 (Mar. 17, 2003) ("The United Nations Security Council has not lived up to its responsibilities, so we will rise to ours."). 
There is probably no definitive way to disprove the argument that the Bush administration was set on invading Iraq no matter what happened at the United Nations. One might speculate in response that had there been no plausible legal justification whatsoever available to the Bush administration, then no foreign states would have allied themselves with the United States, U.S. public opinion would not have shifted, and the Bush administration ultimately would have continued to pursue weapons inspections rather than an invasion, or would have engaged in a lesser use of force (akin to the bombings of 1998). The importance of the internal and external factors discussed above provide some support to such speculation, but cannot lead to any definitive conclusions.

At the same time, it appears mistaken to draw sweeping conclusions from the fact of the U.S. invasion of Iraq about the general efficacy of international rules on the use of force or the utility of the Security Council. First, there are reasons why this particular incident is not representative when considering the overall value of international rules on the use of force. Given its power, the United States is clearly less susceptible to international rules that seek to restrict the options of states in resorting to force; yet, this is not true of most other states, who appear much more susceptible to the international normative code. Conversely, Iraq as a target state presented a very unique situation: Iraq's claims to the benefits of "territorial sovereignty and political independence" recognized within international law were far weaker than would be the case for other states. Had Iraq not been a country that was ruled by a despotic government, had Iraq not been a country that twice had invaded its neighbors in recent history, had Iraq not been a country that, without question, resisted and evaded its international obligations over the course of a dozen years, then the costs of the United States in proceeding with the intervention without Security Council authorization-both at home and abroad - would have been far greater, so much so that the United States might well have 
refrained from doing so or from doing so in the manner that it did (e.g., might have given the process of UN inspections more time).

To demonstrate the point, consider what would happen if a new Mexican president threatened either to bar oil exports to the United States or to significantly increase the price of such oil exports, prompting some members of the Bush administration to argue in favor of invading Mexico to obtain control of its oil reserves. Obtaining such oil reserves would clearly advance U.S. interests, so why not do it? Based on the factors discussed above, it seems likely that other members of the Bush Administration, the Congress, U.S. public opinion, and foreign opinion would view the invasion as wrong. That assessment of wrongfulness would be couched in terms of maintaining international stability through adherence to a normative code that disfavors uses of force, except in self-defense or under Security Council authorization. There would be no credible basis for arguing that the United States was acting in self-defense; claims that U.S. national security required an invasion to secure energy resources would be regarded as weak. Unlike Iraq, Mexico's claims to rights of sovereignty would be strong and would not be undermined by its past behavior; certainly, there would be no framework of past intervention by the global community in Mexico upon which to hang an argument that the U.S. invasion constitutes norm enforcement. Indeed, to the extent that the U.S. use of force was viewed as not just unlawful, but also grossly unjust, the costs to the United States would include the loss of cooperation by other states in global conflict management that the United States cares about, including the deployment of UN peacekeeping operations (which allow U.S. forces to avoid patrolling global "hot spots") and the imposition of UN sanctions binding on all states (including sanctions on terrorist organizations). ${ }^{273}$ As such, the invasion of Mexico would

${ }^{273}$ See, e.g., SC Res. 1267 (Oct. 15, 1999); SC Res. 1373 (Sept. 28, 2001); SC Res. 1390 
not go forward.

(Jan. 16, 2002) (establishing a UN financial sanctions committee which maintains lists of persons associated with terrorism and providing that the assets of such persons must be frozen by all states). 
Similarly, drawing sweeping conclusions about the utility of the Security Council based on the U.S. invasion of Iraq is just as mistaken as drawing sweeping conclusions about the efficacy of international norms. There is little doubt that, with the invasion of Iraq, the world's preeminent superpower deviated from the clear will of the majority of the Security Council. Yet the standard for judging the utility of the Security Council can hardly rest on whether it is successful in blocking a major military power from pursuing its national interests. The Security Council is not up to that task; indeed, given the presence of the veto power, the Security Council was never designed to serve such a function. Yet it serves so many other functions, that the glass would seem to be at least half full. Since 1948, the Security Council has authorized more than fifty peacekeeping operations worldwide to stem violence and maintain peace. Currently, some 37,000 peacekeepers are deployed for 14 peacekeeping operations, from East Timor to East Africa, from Cyprus to Sierra Leone. While such operations are often only partially successful, they represent a qualitative advancement over a world where no collective security efforts exist at all, ${ }^{274}$ and they are made possible by the presence of a coordinating and legitimizing agency in the form of the Security Council. When peacekeeping operations fail or are inadequate, sometimes the major powers on the Security Council are able agree to (or acquiescence in) an authorization for states, acting in their national capacity, to use military force. There is no reason to expect that this function will change in the aftermath of the U.S. invasion of Iraq. Indeed, just a few weeks after the invasion, the Security Council authorized a French-led multinational force to deploy to the Congo, for the purpose of helping to

${ }^{274}$ See, e.g., Virginia Page Fortna, Scraps of Paper? Agreements and the Durability of Peace, 57 INT'L ORG. 337, 359-60 (2003) (finding that "there is a large and statistically significant difference between cease-fires overseen by a fresh set of international peacekeepers and those without the benefit of peacekeeping."). 
stem violence in that country that had claimed 3.3 million lives in less than five years. ${ }^{275}$ The United States itself drafted and sponsored a resolution adopted in August 2003 authorizing the deployment of a multinational peace force to Liberia charged with supporting the implementation of a cease-fire agreement in that war-ravaged country. ${ }^{276}$ Even the U.S. campaign to control WMD is furthered by the availability of the Security Council or U.N. specialized agencies, such as the International Atomic Energy Agency, to serve particular functions short of the use of force. ${ }^{277}$

Second, if one is to draw sweeping conclusions from the invasion of Iraq, one conclusion might be that the stakes have now been raised considerably for states that might otherwise be inclined to thwart Security Council resolutions. Indeed, some in the United States and the United Kingdom viewed the issue of whether to invade Iraq as really an issue of whether the United Nations credibility and effectiveness could possibly endure in the face of a government that over the course of more than a decade repeatedly flouted direct orders of the Security Council—a "League of Nations" moment (Manchuria in 1931 or Ethiopia in 1935) transposed to the twenty-first century. ${ }^{278}$ In this sense, the U.S. legal theory for the invasion of Iraq helps bolster the objectives and purposes

275 See SC Res. 1484 (May 30, 2003); Somini Sengupta, Congo War Zone Awaits French Troops Skeptically, N.Y. TIMES, June 6, 2003, at A8.

276 S.C. Res. 1497 (Aug. 1, 2003).

${ }^{277}$ See, e.g., Michael Dobbs, U.S. Using U.N. to Thwart Iran's Nuclear Program, WASH. Post, June 23, 2003, at A12; Michael Dobbs, European Leaders Back U.S. on Iran Nuclear Inspections, WASH. POST, June 26, 2003, at A20.

${ }^{278}$ See, e.g., The President's News Conference, supra note 190, at 297 (“This is not only an important moment for the security of our Nation; I believe it's an important moment for the Security Council, itself. And the reason I say that is because this issue has been before the Security Council - the issue of disarmament of Iraq - for 12 long years. And the fundamental question facing the Security Council is, will its words mean anything? When the Security Council speaks, will the words have merit and weight?"). 
of the United Nations, for the United States and the United Kingdom repeatedly asserted that they were seeking to enforce UN norms. ${ }^{279}$

${ }^{279}$ For perspectives on such a teleological interpretation of UN Charter norms, compare Ruth Wedgwood, Unilateral Action in the UN System, 11 EuR. J. INT'L L. 349, 353 (2000) (finding a system of inaction more troublesome than the danger of provoking a veto-wielding major power) with Gowlland-Debbas, supra note 98, at 374 (stating that a teleological approach to the Charter "is not intended to be used for a reactionary purpose, i.e. reversion to a sovereign unfettered right on the part of one or several states to usurp Council powers."). On the need to maintain a balance between power (or effectiveness) and legitimacy (or justice), see Bruce Russett, Ten Balances for Weighing UN Reform Proposals, in THE ONCE AND FutURE SECURITY CounCIL, supra note 119, 2 at 18-21. 
Third, an argument that U.S. actions against Iraq or elsewhere "leave the system of collective security severely damaged" ${ }^{\prime 280}$ is only persuasive if one believes that the system had been wellfunctioning to begin with. Yet, the United Nations has never functioned as a flawless mechanism for collective security, capable of stopping major powers from deploying military force when their national interests so dictate. ${ }^{281}$ Since 1945 , states on numerous occasions have used force against other states in a manner that appears to fall outside the norms established by the UN Charter, including force by permanent members. For many observers, the United States had no more justification for invading and deposing the government of the Dominican Republic in 1965 or in Panama in 1989 than it did for invading Iraq in 2003. Nor were France and the United Kingdom regarded as justified in attacking Egypt during the Suez crisis in 1956-57. Nor were the Soviets justified in invading Afghanistan in 1979. Indeed, some of the states most vocally opposed to the U.S. invasion of Iraq on grounds of lack of Security Council authorization, had no difficulty four years earlier in attacking Serbia solely on NATO authorization. ${ }^{282}$

${ }^{280}$ Krisch, supra note 19 , at 100.

${ }^{281}$ See generally Nigel D. White, The United NATIONS AND THE MAINTENANCE OF INTERNATIONAL PEACE AND SECURITY (1990); see also Wedgwood, Unilateral Action in the UN System, supra note 281, at 349-52 (noting, among other things, that during the Cold War the "central architecture of stability was provided by defensive alliances, not by commitments of the UN Security Council."). Organizational theorists would characterize the Security Council as an "open system," meaning that as an institution it is highly sensitive to the environment in which it operates (i.e., reliance on the support of the major powers), and thus highly dependent upon that environment. As such, to remain effective, the Security Council cannot seek to control its environment; instead, it must adapt and be responsive to that environment, "both to maintain the ability to mobilize states and other acts and also to monitor impending crises." Ian Hurd, Security Council Reform: Informal Membership and Practice, in THE ONCE AND FUTURE SECURITY COUNCIL, supra note 119, 135 at 139-41.

282 The legality of the bombing campaign against Serbia has also been a subject of disagreement among states and legal scholars. See generally Editorial Comments: NATO's 
None of those invasions had Security Council authorization and none were undertaken in self-defense against an armed attack within the meaning of Article 51 of the UN Charter. Yet, such deviations from traditional rules on the use of force, which no doubt will occur again in the future, do not discredit the remarkable gains in outlawing the transnational use of force over the past sixty years. In considering the effectiveness of international rules on the use of force, Oscar Schachter's admonition twenty years ago remains true today: "Never before in history has there been such widespread and well-founded recognition of the costs and horrors of war. That awareness and its objective basis are powerful factors in strengthening the conscious self-interest in avoiding armed conflict. ${ }^{283}$ The global unease with the U.S. invasion of Iraq is a testament to the enduring nature of that conscious self-interest, and belie any belief that the state of nature in the global community

Kosovo Intervention, 93 AM. J. INT’L L. 824 (1999). Some states advanced arguments that referenced prior Security Council resolutions - specifically Resolution 1199 (Sept. 23, 1998) and Resolution 1203 (Oct. 24, 1998) - suggesting that they provided a form of implied authorization from the Security Council. For the U.S. position, see SEAn D. Murphy, United States PRACTICE IN INTERNATIONAL LAW, 1999-2001, at 393-94 (2002).

${ }^{283}$ Oscar Schachter, The Right of States to Use Armed Force, 82 Mich. L. REv. 1620, 1620 (1984); see also Oscar Schachter, In Defense of International Rules on the Use of Force, 53 U. CHI. L. REV. 113 (1986). 
of states is nasty, brutish, and short. ${ }^{284}$

\section{CONCLUSION}

The legal theory advanced in 2003 by the United States and its allies to justify the invasion of Iraq is not persuasive. Neither the language of the relevant resolutions, nor the practice of the Security Council with respect to those resolutions, supports the use of force against Iraq, especially in light of the extensive opposition of most of the members of the Security Council over the course of 2002-2003. The willingness of the United States to proceed with the invasion in the face of such opposition certainly calls into question the utility of international norms on the use of force and the Security Council as a vehicle for collective security. Nevertheless, there are some reasons to see this incident as a reaffirmation by the global community of the core norms underlying the Charter use of force paradigm, and as reflecting a degree of "compliance pull" upon the United States and other major powers even if, ultimately, the United Nations cannot prevent such powers from pursuing what they perceive as in their fundamental national security interests.

${ }^{284}$ Thomas Hobbes famously described the state of nature of man in the absence of government in such terms. See Thomas HobBes, Leviathan, pt. I, ch. 13 [1651]. 